
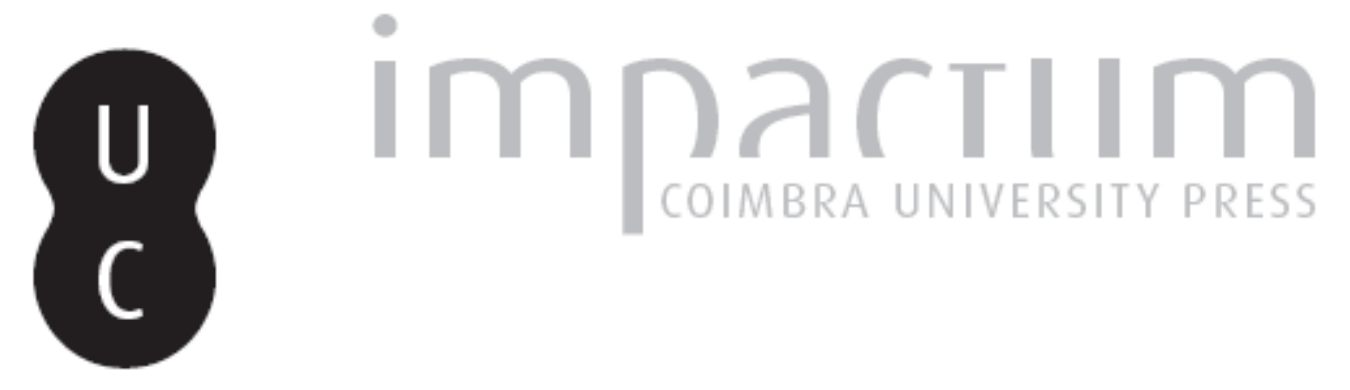

\title{
Princípio da precaução: manual de instruções
}

\section{Autor(es): $\quad$ Aragão, Alexandra}

\section{Publicado por: CEDOUA}

URL persistente:

URI:http://hdl.handle.net/10316.2/8833

DOI: http://dx.doi.org/10.14195/2182-2387_22_1

Accessed : $\quad$ 26-Apr-2023 14:32:02

A navegação consulta e descarregamento dos títulos inseridos nas Bibliotecas Digitais UC Digitalis, UC Pombalina e UC Impactum, pressupõem a aceitação plena e sem reservas dos Termos e Condições de Uso destas Bibliotecas Digitais, disponíveis em https://digitalis.uc.pt/pt-pt/termos.

Conforme exposto nos referidos Termos e Condições de Uso, o descarregamento de títulos de acesso restrito requer uma licença válida de autorização devendo o utilizador aceder ao(s) documento(s) a partir de um endereço de IP da instituição detentora da supramencionada licença.

Ao utilizador é apenas permitido o descarregamento para uso pessoal, pelo que o emprego do(s) título(s) descarregado(s) para outro fim, designadamente comercial, carece de autorização do respetivo autor ou editor da obra.

Na medida em que todas as obras da UC Digitalis se encontram protegidas pelo Código do Direito de Autor e Direitos Conexos e demais legislação aplicável, toda a cópia, parcial ou total, deste documento, nos casos em que é legalmente admitida, deverá conter ou fazer-se acompanhar por este aviso.

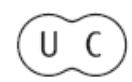




\section{Princípio da precaução: manual de instruções*}

\section{Resumo}

Um dos factores que mais contribuiu para as dúvidas e receios, que actualmente envolvem o princípio da precaução, foi a rapidez da sua disseminação no discurso político, jornalístico, e até na linguagem comum. Procurando corresponder às preocupações do Conselho Europeu no ano 2000, vamos procurar reforçar o conhecimento e promover a clarificação de um princípio que beneficia de "unção jurisdicional" pelos tribunais europeus desde há cerca de uma década, mas ao qual falta ainda a bênção dos tribunais nacionais.

\section{Surgimento e evolução do princípio da precaução}

Apesar de Bruno Latour, considerar que um princípio da precaução não tem um verdadeiro "pedigree filosófico" ${ }^{2}$, é habitual situar as primeiras referências à ideia de precaução, na década de 70, nos escritos de Hans Jonas. Na sua obra de 1979, sobre o Princípio da responsabilidade ${ }^{3}$, o filósofo alemão considera a energia nuclear e a clonagem como ameaças à humanidade, das quais faz decorrer uma "ética do futuro" $\mathrm{e}$ uma obrigação precaucional transgeracional de evitar catástrofes 5 .

\footnotetext{
* $O$ título do presente estudo pretende ser uma referência à inspiradora obra de Buckminster Fuller em 1969, Manual de Instruções para a Nave Espacial Terra, na qual o autor imagina o nosso planeta como um satélite artificial: "A Nave Espacial Terra foi tão extraordinariamente bem inventada e concebida que, tanto quanto sabemos, os humanos estiveram a bordo dela durante dois milhões de anos sem nunca se terem apercebido de que se encontravam a bordo de uma nave espacial (...) A propositada omissão do livro de instruções sobre como operar e conservar a Nave Espacial Terra e os seus complexos sistemas regeneradores e de apoio à vida, forçou o homem a descobrir, retrospectivamente, quais eram exactamente as suas aptidões prospectivas mais importantes". (Manual de Instruções para a Nave Espacial Terra, Porto, Via Óptima, 1998, p. 29-31). Ora, tal como o planeta Terra, o princípio da precaução também veio sem "manual de instruções".

${ }^{1}$ Nicolas de Sadeleer, "Les Avatars du Principe de Précaution en Droit Public. Effet de Mode au Révolution Silencieuse?» in: Revue Française de Droit Administratif, 2001, Mai-Juin, p.548.

${ }^{2}$ «Du principe de précaution au principe du bon gouvernement: vers de nouvelles règles de la méthode expérimentale», in: Politiques de la nature. Comment faire entrer les sciences en démocratie. Paris, La Découverte, 1999, p.339. ${ }^{3}$ Le principe de responsabilité. Une éthique pour la civilisation technologique, Ed. Champs, Flammarion, Paris, 1999. (tradução da edição original Das Prinzip Verantwortung. Versuch einer Etik für die technologische Zivilization, Frankfurt, 1979).

${ }^{4}$ Op. cit, p. 63.

${ }_{5}^{5}$ Segundo Frédérick Lemarchand, o termo catástrofe tem uma etimologia ligada ao teatro. Catástrofe seria precisamente a última estrofe de uma tragédia grega. Seria portanto o fim de uma história com um desenlace funesto. (Catástrofe, in: Dictionaire des Risques, Yves Dupont (dir), Armand Colin, Paris, 2007, p.75-80).
} 
Também na Alemanha, em 1974, a Lei Federal de Protecção Contra Emissões (BundesImmissionsschutzgesetz) consagra, pela primeira vez, o princípio da precaução no âmbito da poluição atmosférica ${ }^{6}$.

Porém, é na década de 90 que este princípio começa a ganhar um reconhecimento doutrinal mais generalizado e a receber consagração mais frequente em instrumentos de Direito Internacional.

Em 1992, o princípio da precaução surge na Declaração do Rio, na Cimeira das Nações Unidas sobre ambiente e desenvolvimento, na Convenção das Nações Unidas sobre a Diversidade Biológica, na Convenção-Quadro das Nações Unidas sobre Alterações Climáticas, nas Convenções de Helsínquia sobre a Protecção e a Utilização dos Cursos de Água Transfronteiriços e dos Lagos Internacionais e sobre a protecção do ambiente marinho do Mar Báltico, na Convenção para a Protecção do Meio Marinho do Atlântico Nordeste, e no Tratado de Maastricht, que institui a União Europeia.

0 ano 2000 foi, na Europa, outro ano marcante para este princípio:

- A Comissão Europeia adopta uma extensa Comunicação ${ }^{7}$ apenas sobre o modo de "utilizar o princípio da precaução", uma espécie de interpretação autêntica deste princípio;

- O Conselho Europeu de Nice, em 9 de Dezembro, aprova uma Resolução, na qual formula um convite aos Estados Membros para que reforcem o conhecimento e promovam a clarificação do princípio da precaução (ponto 25);

- No Tribunal de Primeira Instância das Comunidades Europeias, corre o processo Pfizer (T-13/99), um recurso de anulação interposto pela multinacional farmacêutica Pfizer contra um Regulamento da Comissão Europeia, que retirou a autorização para utilização da virginiamicina como aditivo na alimentação animal. 0 Acórdão de 11 de Setembro de 2002, favorável à Comissão Europeia, analisa o risco de transferência da resistência aos antibióticos dos animais, para o Homem, à luz do princípio da precaução.

Dez anos passados, a aceitação do princípio da precaução vai-se pacificando e começa a dar frutos o reconhecimento de que, por causa do princípio da integração ${ }^{8}$, o princípio da precaução não se aplica só à política ambiental, mas a todas as políticas da União Europeia.

De facto, ao nível do Direito europeu em vigor, o peso do princípio da precaução é, actualmente, esmagador: 76 actos jurídicos contêm referências expressas ao princípio da precaução e outros 255 têm, pelo menos, menções à precaução ou a estratégias precaucionais`. Um número total de 301 documentos oficiais europeus em vigor, com referências directas à precaução, fazem dele um princípio fundamental, não apenas de Direito Ambiental mas de Direito Europeu, em geral. Em 2002 o Tribunal Europeu de Primeira Instância afirmou-o expressamente no caso Artegodan ${ }^{10}$.

\footnotetext{
${ }^{6}$ Analisando a exportação da "receita alemã de Vorsorge“, Sonja Boehmer-Christiansen ("The Precautionary Principle in Germany,- Enabling Government”, in: Timothy O’Riordan e James Cameron, (ed.) Interpreting the Precautionary Principle, Earthscan, 1994) , alude ao significado literal da palavra alemã que esteve na origem do princípio da precaução: Vorsorge significa "cuidado e preocupação pévios"(p. 38) e conclui que "embora vaga, a ideia de precaução teve um papel poderoso na política ambiental germânica, estabelecendo objectivos ambiciosos e indicando um conjunto de mecanismos através dos quais a política devia evoluir para os alcançar (p. 55).“

7 COM(2000) 1 final, Bruxelas, de 2 de Fevereiro de 2000.

${ }^{8}$ Elisabeth Fisher, Judith Jones, René von Schomberg, Implementing the Precautionary Principle. Perspectives and Prospects, Edward Elgar, Cheltenham, 2008, p.4.

9 Apesar de alguns autores acentuarem a importância da distinção entre aproximação precaucional e princípio da precaução, concordamos com Rosie Cooney que desvaloriza e considera a distinção como uma questão meramente semântica ("A Long and Winding Road? Precaution from Principle to Practice in Biodiversity Conservation", in: Implementing the Precautionary Principle. Perspectives and Prospects, Edward Elgar, Cheltenham, 2008 p. 223.) ${ }_{10}$ "O princípio da precaução pode ser definido como um princípio geral de Direito Comunitário que exige que as autoridades competentes tomem medidas para prevenir determinados riscos potenciais para a saúde pública, a segurança e o ambiente, dando precedente às exigências relacionadas com a protecção desses interesses em relação aos interesses económicos" (Processos apensos T-74/00, T-76/00, T-83/00 to T-85/00, T-132/00, T-137/00 e T-141/00, com acórdão de 26 de Novembro de 2002).
} 
Na realidade, no vasto conjunto de actos jurídicos de inspiração precaucional, encontramos temáticas tão díspares como a segurança dos produto ${ }^{11}$, a protecção contra pandemias e epizootias ${ }^{12}$, a conservação de espécies e ecossistemas ${ }^{13}$, as nanotecnologias, as emissões poluentes, a gestão territorial de zonas sensíveis, avaliação ambiental de planos e programas, ou até doações de sangue.

É um facto incontornável que, apesar de ter surgido num contexto ambiental, actualmente vemos o princípio da precaução aplicado em contextos muito diferentes ${ }^{14}$. Além dos temas mais próximos, como a saúde pública (em sentido amplo, abrangendo a saúde das pessoas, dos animais e ainda a protecção vegetal), a protecção dos consumidores ou a agricultura, tem sido invocado igualmente em matéria de comércio internacional (nomeadamente casos junto da Organização Mundial de Comércio, concretamente quanto aos acordos sobre medidas sanitárias e fitosanitárias e sobre barreiras técnicas ao comércio ${ }^{15}$, a propósito de aditivos alimentares à base de hormonas, do amianto, dos organismos geneticamente modificados), no direito da família (por exemplo, no Tribunal Europeu dos Direitos do Homem, a sua aparição em casos de regulação do poder paternal ${ }^{16}$ tem sido recorrente) e até em direito orçamental, aplicado ao cálculo das receitas ${ }^{17}$.

A proliferação das referências legais leva-nos a afirmar, com Cécile Castaing, que o princípio da precaução hoje corresponde "tanto a uma vontade política como a uma necessidade jurídica" ${ }^{18}$.

\footnotetext{
${ }^{11}$ Diplomas sobre segurança geral dos produtos, cosméticos, segurança dos brinquedos, fórmulas para lactentes, alimentos à base de cereais e alimentos para bebés destinados a lactentes e crianças jovens, restrição do uso de determinadas substâncias perigosas em equipamentos eléctricos e electrónicos, resíduos de equipamentos eléctricos e electrónicos, substâncias indesejáveis nos alimentos para animais, segurança dos géneros alimentícios, classificação, embalagem e rotulagem das substâncias perigosas, produtos químicos, fitofarmacêuticos, máquinas de aplicação de pesticidas e organismos geneticamente modificados.

${ }^{12}$ Nomeadamente sobre leite e produtos à base de leite provenientes de uma exploração na qual foi confirmado um caso de tremor epizoótico clássico, o nemátodo da madeira do pinheiro, regras para a prevenção, o controlo e a erradicação de encefalopatias espongiformes transmissíveis.

${ }^{13}$ Sobre conservação dos ecossistemas marinhos da zona do Voordelta, a protecção dos ecossistemas marinhos vulneráveis do alto mar, a utilização na aquicultura de espécies exóticas e de espécies ausentes localmente, a protecção e utilização dos cursos de água transfronteiras e dos lagos internacionais, a conservação das Aves Aquáticas migradoras Afro-Eurasiáticas, a protecção do meio marinho do Atlântico Nordeste, a cooperação para a protecção e utilização sustentável do Danúbio, a conservação e exploração sustentável dos recursos haliêuticos, a conservação dos recursos da pesca através de determinadas medidas técnicas de protecção dos juvenis de organismos marinhos, as pescas do Atlântico Nordeste, as possibilidades de pesca e condições associadas, aplicáveis nas águas comunitárias.

${ }^{14}$ Sobre a evolução das políticas públicas induzidas pelos riscos, ver Pontier, Jean-Marie, «Le droit de la prévention des risques, droit en devenir des sociétés développées, d'aujourd'hui et de demain», in: Les plans de prévention des risques, Université Paul Cézanne- Aix Marseille III, 2007, p. 49 e ss. Michel Franc chama a atenção para o facto de o princípio da precaução, em França, se estender a outros sectores que correspondem, cada um deles, a um escândalo: a qualidade da fabricação de produtos (dioxinas, vacas loucas), a qualidade das construções (amianto), a qualidade dos cuidados prestados em estabelecimentos de saúde (sangue contaminado com o vírus da SIDA) («Traitement Juridique du risque et principe de précaution», in: Actualité Juridique Droit Administratif, n. $-8,3$ Mars, 2003, p. 361).

${ }^{15}$ Designados, respectivamente por SPS, da designação em língua inglesa Sanitary and Phitosanitary Measures e TBT ou Technical Barriers to Trade, ambos no anexo $1 \mathrm{~A}$ ao acordo que estabelece o Organização Mundial de Comércio. ${ }^{16}$ Por exemplo o caso Neulinger and Shurukv. Switzerland, de 8 de Janeiro de 2009.

${ }^{17}$ No artigo "Prudent Budgetary Policy. Political Economy of precautionary taxation" (CESifo - Münchener Gesellschaft zur Förderung der Wirtschaftswissenschaften - working paper, n.ํㅜㅁ73, de Abril de 2007), Frederick van der Ploeg funda um dever de sub-estimar as receitas para não correr riscos de desequilíbrio orçamental precisamente no princípio da precaução.

18 “La mise en œuvre du principe de précaution dans le cadre du référé suspension”, in: Actualité Juridique Droit Administratif, nํ43, 15 Décembre 2003, p.2297.
}

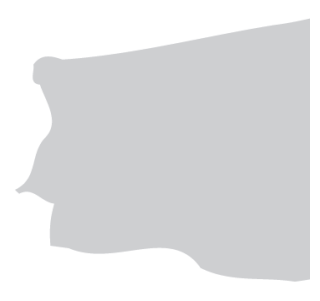


Doutrinalmente, os desenvolvimentos teoréticos sobre o princípio da precaução resultam da expansão da "riscologia" ${ }^{9}$.

Porém, continua a haver, na Europa e fora dela, quem pretenda diluir o princípio da precaução no princípio da prevenção, ou pior ainda, quem advogue a supressão de um princípio "vago com definições conflituantes"

Ora, não termos certezas em relação à força de um princípio, cujo âmbito de aplicação é tão vasto, e cujos efeitos podem ser tão drásticos, é assustador, sobretudo em matéria ambiental e na Europa, onde o dever, imposto pela União Europeia, de prevenção de riscos, por parte dos Estados, abrange não só os riscos tecnológicos mas também já os riscos naturais ${ }^{21}$.

\section{Riscos naturais e riscos antrópicos}

A prevenção de acidentes, tanto de origem natural como antrópica, é uma preocupação crescente da União Europeia (manifestada em Resoluções do Parlamento Europeu ${ }^{22}$, Conclusões do Conselho Europeu ${ }^{23}$, Comunicações da Comissão Europeia ${ }^{24}$ ) que culminou na introdução de um novo artigo ${ }^{25}$ no Tratado sobre o Funcionamento da União referente à prevenção das catástrofes ${ }^{26}$.

$\overline{{ }_{19} E \text { Georges Jousse }}$ que usa o termo «riscologia» para referir o conjunto das ciências que estudam o risco (Traité de riscologie - La science du risque, Imestra Éditions, 2009). Ortwin Renn classifica as várias perspectivas do risco em sete abordagens diferentes: contabilística, toxico-epidemiológica, probabilística, económica, psicológica, sociológica e cultural (“Concepts of Risk: a Classification”, in: Social Theories of Risk, Sheldon Krimsky e Dominic Golding (Ed) Praeger, London, 1992, p. 57).

${ }^{20}$ Nancy J. Myers, e Peter Montague, in: Precautionary tools for reshaping environmental policy, the MIT press, Cambridge, Massachusetts, 2006, p. 120-123.

${ }^{21}$ É o caso das inundações, reguladas pela Directiva 2007/60, de 23 de Outubro de 2007, cujo prazo de transposição para o ordenamento jurídico português terminou em 26 de Novembro de 2009.

${ }_{22}$ Resolução de 19 de Junho de 2008 sobre o aprofundamento, pela União Europeia, da capacidade de resposta aos desastres.

${ }^{23}$ Conclusões de 16 de Junho de 2008.

${ }^{24}$ Comunicação da Comissão ao Parlamento Europeu, ao Comité Económico e Social e ao Comité das Regiões sobre uma Aproximação Comunitária à Prevenção de Catástrofes de Origem Natural e Humana (COM (2009) 82 final, Bruxelas, 23.2.2009) que identifica como elementos chave a criação de um inventário de informação sobre catástrofes, a difusão de melhores práticas, o desenvolvimento de linhas orientadoras sobre riscos e mapeamento de riscos, o apoio a actividades de investigação, a ligação entre os actores ao longo do ciclo de gestão de catástrofes, etc.. 25 O artigo 196. do Tratado sobre o Funcionamento da União, relativo à protecção civil, integra-se no título XXIII da Parte III, sobre as políticas e acções internas da União, onde surge a par do mercado interno, da livre circulação de mercadorias, pessoas, serviços e capitais, da agricultura e pescas, da saúde pública, da defesa dos consumidores, das redes transeuropeias, do ambiente, da energia, etc.

O 1. do artigo 1960 define o âmbito de actuação da União Europeia em matéria de protecção civil: "1. A União incentiva a cooperação entre os Estados-Membros a fim de reforçar a eficácia dos sistemas de prevenção das catástrofes naturais ou de origem humana e de protecção contra as mesmas. A acção da União tem por objectivos:

a) Apoiar e completar a acção dos Estados-Membros ao nível nacional, regional e local em matéria de prevenção de riscos, de preparação dos intervenientes na protecção civil nos Estados-Membros e de intervenção em caso de catástrofe natural ou de origem humana na União;

b) Promover uma cooperação operacional rápida e eficaz na União entre os serviços nacionais de protecção civil; c) Favorecer a coerência das acções empreendidas ao nível internacional em matéria de protecção civil.

2. O Parlamento Europeu e o Conselho, deliberando de acordo com o processo legislativo ordinário, estabelecem as medidas necessárias destinadas a contribuir para a realização dos objectivos a que se refere o n.ำ 1 , com exclusão de qualquer harmonização das disposições legislativas e regulamentares dos Estados-Membros."

A protecção civil é, portanto, um domínio em que "A União dispõe de competência para desenvolver acções destinadas a apoiar, coordenar ou completar a acção dos Estados-Membros”. (artigo 6ㅇ do mesmo Tratado).

${ }^{26}$ Marie-Béatrix Crescenzo-d'Auriac procura definir o limiar a partir do qual uma ocorrência assume dimensões catastróficas (Les Risques Catastrophiques, Évènements Naturels Politiques et Technologiques, L’Argus, Paris, 1988, p.13 e ss.). 
Em regra, considera-se que os riscos naturais são riscos excepcionais, concentrados e heterogéneos e, por isso, mais dificilmente seguráveis"27, enquanto os riscos ditos "tecnológicos" são estatisticamente mais frequentes, mais disseminados no tempo e no espaço e relativamente homogéneos, logo, mais seguráveis.

Porém, a distinção entre riscos de origem natural e riscos de origem humana é cada vez mais subtil ${ }^{28}$. Existem diversas formas pelas quais causas naturais (físicas, meteorológicas, geológicas ou biológicas) podem potenciar riscos antrópicos e vice-versa, dando origem a acidentes mistos. Sendo os riscos climáticos ${ }^{29} 0$ exemplo máximo dessa indistinção, vamos dar três exemplos baseados em fenómenos desta natureza. Para Abelkhaleq Berramdane ${ }^{30}$, hipóteses destas poderão ser consideradas como catástrofes naturais ou como acidentes tecnológicos, consoante privilegiemos a causa primária ou a causa imediata.

a) Causas naturais extraordinárias: Um fenómeno natural nada habitual, que cria riscos tecnológicos. Por exemplo, a passagem de um furacão de escala 5 , com ventos superiores a $249 \mathrm{~km} / \mathrm{h}$, que está na origem do risco de explosão de uma fábrica de indústria química no Barreiro ${ }^{31}$.

b) Causas naturais invulgares: Um fenómeno natural ordinário, mas com uma intensidade surpreendente e que, por isso, potencia o risco tecnológico. 0 exemplo são chuvas diluvianas em Santarém que põem uma barragem, como a de Castelo de Bode, em risco de ruptura, por falta de capacidade do descarregador de cheias.

c) Causas naturais ordinárias. Um fenómeno natural habitual, com uma intensidade dentro dos valores normais, mas cujos efeitos danosos são profundamente agravados por factores humanos ${ }^{32}$ intensificados ao longo do tempo. A melhor ilustração é o risco de inundação e aluimentos na ilha da Madeira, na sequência da remoção do coberto vegetal e da impermeabilização progressiva do solo, pela urbanização excessiva das encostas da ilha33.

\footnotetext{
${ }_{27}$ Kerry H. Whiteside, a propósito das responsabilidades ingeríveis das alterações climáticas, afirma: "Onde as seguradores não se atrevem a ir, os governos entram em cena" (Precaucionary Politics. Principle and Practice in Confronting Environmental Risk, Massachusetts Institute of Technology", 2006, p. 32)

${ }^{28}$ Sobre a relativização da distinção entre riscos naturais e antrópicos, ver Jean-Marie Pontier, «Le droit de la prévention des risques, droit en devenir des sociétés développées, d'aujourd'hui et de demain», in Les plans de prévention des risques, Université Paul Cézanne- Aix Marseille III, 2007, p. 36 e ss. Pierre Martin reafirma a dificuldade de distinguir os riscos com e sem interferência humana, mas esforça-se por provar que existem acções e meios racionais para prevenir os efeitos de fenómenos como sismos, inundações, deslizamento de terras, vulcões, etc. (Ces Risques que l'on Dit Naturels, Eyrolles, Paris, 2006, p. 367 a 405).

${ }^{29}$ As alterações climáticas têm ocasionado impactes dificilmente previsíveis. Um exemplo citado por Joren van der Sluijs e Wim Turkenburg ("Climate Change and the precautionary principle", in: Implementing the Precautionary Principle. Perspectives and Prospects, Edward Elgar, Cheltenham, 2008 p. 249) foi o colapso de um dique na Holanda, num período de seca extrema, levando à inundação da aldeia de Wilnis, perto de Amesterdão. Estudos posteriores revelaram que o imprevisível colapso se deveu à secura extrema da turfa que se encontra na terra com que são construídos muitos dos diques na Holanda. Milhares de quilómetros de diques feitos de terra contendo turfa estão nas mesmas condições...

Sobre as situações climáticas perigosas ao longo da história ver Emmanuel le Roy Ladourie, «L'historien face à l'histoire climatique et à l'attitude des autorités en cas de conjoncture «climatico-perilleuse», in: Les pouvoirs publics face aux risques naturels dans l'histoire. Publications de la MSH-Alpes, 2005, p.13 a 29.

${ }_{30}$ "L'Obligation de prévention des catastrophes et risques naturels», in: Revue du Droit Public et de la Science Politique en France et a l'Étranger, n.ㅇ, 1997, p. 1717.

${ }^{31}$ Os especialistas das empresas resseguradoras especializadas em riscos climáticos admitem a probabilidade de, em virtude do aquecimento global, dentro de duas ou três décadas Lisboa vir a ser afectada por furacões (http:// www.climate-insurance.org).

32 "Os factores humanos de agravamento ou de despoletamento de catástrofes naturais são frequentemente difusos, contínuos e difíceis de delimitar e impossíveis de recensear na sua totalidade" (Philippe Ségur, «La catastrophe et le risque naturels : essai de définition juridique» in: Revue du Droit Public et de la Science Politique en France et a l'Étranger. - 0035-2578. - N. 6 (1997), p. 1699). O autor dá o exemplo do êxodo rural, da desflorestação, da construção de túneis, estradas, canalizações, diques, barragens, etc..

33 Riscos que se vieram a concretizar no início de Fevereiro de 2010.
} 
A dificuldade de distinção entre riscos naturais e antrópicos foi ultrapassada, no caso da Lei de Bases da Protecção Civil, (Lei n. 0 27/2006 de 3 de Julho), acabando simplesmente com a distinção nas definições legais de acidente grave e de catástrofe. Esta constitui uma alteração substancial em relação às definições constantes da lei anterior, a Lei no $113 / 91$, de 29 de Agosto. Onde antes se lia: "catástrofe é um acontecimento súbito quase sempre imprevisível, de origem natural ou tecnológica, susceptível de provocar vítimas e danos materiais avultados, afectando gravemente a segurança das pessoas, as condições de vida das populações e o tecido sócio-económico do país" (artigo $2^{2}{ }^{\circ}$, n. ${ }^{-2}$ ), pode ler-se, desde 2006: "catástrofe é o acidente grave ou a série de acidentes graves susceptíveis de provocarem elevados prejuízos materiais e, eventualmente, vítimas, afectando intensamente as condições de vida e o tecido sócio-económico em áreas ou na totalidade do território nacional” (artigo 3ํㅡㄴ n.․ㅡㄹ).

Na mesma linha, também nós não diferenciaremos entre precaução de riscos de origem natural e antrópica, primeiro, porque, como já vimos, a distinção tende a diluir-se, e segundo, porque em ambos os casos existe o dever de precaução em relação a riscos evitáveis.

Por outro lado, a relativa previsibilidade científica, mesmo de fenómenos naturais incontroláveis, levou a que o legislador tenha abandonado também, na definição de "catástrofe", da Lei de Bases da Protecção Civil, a referência à imprevisibilidade. Daí defendermos a ideia de que o direito dos cidadãos a serem protegidos, contra riscos previsíveis, excessivos e desnecessários, decorre do direito à liberdade e segurança consagrado internacionalmente na Declaração Universal dos Direitos do Homem (artigo $5^{\circ}$ ), na Convenção Europeia para a protecção dos Direitos do Homem e das Liberdades Fundamentais (artigo $5^{\circ}$ ) e na Carta dos Direitos Fundamentais da União Europeia (artigo 6ำ). No caso da Convenção Europeia, abrir-se-ia uma nova via interpretativa para aplicação da Convenção aos casos, cada vez mais frequentes, que envolvam questões de protecção ambiental.

\section{0 papel do princípio da precaução no Direito}

Um dos factores que contribuiu, de forma determinante, para as dúvidas e receios que actualmente envolvem o princípio da precaução, foi a rapidez da sua disseminação no discurso político, jornalístico, e até na linguagem comum. Tal como já acontecera com o princípio do poluidor pagador, cuja banalização conduziu a uma compressão do seu conteúdo, até ficar reduzido a uma mera dimensão sancionatória do Direito Ambiental ${ }^{34}$, também a vulgarização da ideia de precaução, como bordão de linguagem, contribuiu definitivamente para descredibilizar a precaução, enquanto princípio jurídico ${ }^{35}$.

O nosso propósito com o presente estudo é, portanto, desmistificar o princípio da precaução ${ }^{36}$, defendendo que ele não é, (ao contrário do que diz uma parte da doutrina ${ }^{37}$ ), um

\footnotetext{
${ }^{34}$ Alexandra Aragão, O Princípio do Poluidor Pagador, Pedra Angular da Política Comunitária do Ambiente, Studia luridica, $\mathrm{n} \mathbf{0}_{23}$, Coimbra Editora, 1997 especialmente artigo 131 e ss.

35 Do outro lado do Atlântico, a doutrina norte americana, mantém-se relutante em aceitar um princípio que considera tipicamente europeu. Por isso, Timothy O’Riordan e James Cameron, dizem que o princípio da precaução é um conceito culturalmente marcado (Interpreting the Precautionary Principle, Earthscan, 1994, p. 12). Entre os mais cépticos destaca-se Cass Sunstein que, em Worst Case Scenarios (Harvard University Press, Cambridge, 2007, p. 125-126) afirma: “O problema real com o princípio da precaução, tal como é entendido, é que não oferece qualquer orientação - não que esteja errado mas proíbe todas as acções possíveis, incluindo a regulação. Se for levado a sério é paralizante, proibindo os próprios passos que ele simultaneamente exige.”. Para ilustrar o seu ponto de vista, avança três tipos estilizados de problemas, dando origem a três tipos diferentes de riscos: "O primeiro problema cria uma possibilidade de 999,999 num milhão de que ninguém morra, e uma possibilidade, de um num milhão, de que morram 200 milhões de pessoas. 0 segundo problema cria uma possibilidade de 50 por cento, de que ninguém morra, e uma possibilidade de 50 por cento de que morram 400 pessoas. 0 terceiro problema cria uma percentagem de 100 por cento de que 200 pessoas morram. (...) Se os resultados e as probabilidades forem simplesmente multiplicados, os três problemas são equivalentes: a perda expectável é de 200 vidas". Com este exemplo estereotipado, o autor pretende demonstrar que as grandes catástrofes "não merecem, nem deveriam
} 


\section{$\operatorname{RerCEDöUA~}$

princípio de medo $^{38}$ ou de irracionalidade ${ }^{39}$ mas é, pelo contrário, um princípio racional e cientificamente fundado de "responsabilidade pelo futuro" ${ }^{\circ}$. Na linguagem, expressiva de Lester Brown, diríamos que como o "Plano A" não resultou, precisamos agora de um "Plano B" ${ }^{11}$. O princípio da precaução é o nosso “Plano B”.

receber, menos atenção do que os danos mais prováveis, com um valor esperado equivalente". Na nossa opinião, o erro de raciocínio reside no facto de não fazer sentido multiplicar as probabilidades estatísticas pelo número de mortes para concluir que os problemas são equivalentes. Na terceira hipótese morrem 200 pessoas mas na segunda, se se concretizar, morrem 400 e na primeira, por muito remota que seja a probabilidade, se vier a ocorrer, morrerão 200 milhões de pessoas... Os problemas são diferentes consoante a fonte do dano, a controlabilidade do dano, a previsibilidade do dano, etc. e não podemos pretender torná-los equivalentes pelo simples jogo dos números. ${ }^{36}$ No capítulo "Respondendo às críticas", Nancy J. Myers, e Peter Montague identificam e rebatem rapidamente as principais críticas apontadas ao princípio: um princípio vago com definições conflituantes; como se aplica a tudo deveríamos acabar com toda a tecnologia por causa dele; exige o risco zero, que é um objectivo impossível de alcançar; é desnecessário, porque temos a análise de riscos, é arriscado por impedir a utilização de tecnologias mais seguras; aplicá-lo é demasiado caro; é contra a ciência e é um disfarce para medidas proteccionistas comerciais ("Answering the Critics", in: Precautionary tools for reshaping environmental policy, the MIT press, Cambridge, Massachusetts, 2006, p. 120-123). ${ }_{37}$ Em 2002, Manuel Gros e David Deharbe protagonizaram na Revue du Droit Public et de la Science Politique um exercício de estilo interessante em torno do princípio da precaução (“La Controverse du Principe de Précaution", in: Revue du Droit Public et de la Science Politique en France et à l'Étranger, Mai-Juin 2002, nํ3, p. 821-845).

Manuel Gros coloca-se do lado da acusação e desenvolve uma peça em que o réu é precisamente o princípio da precaução, acusado de ser um conceito fluido e sem consistência, moralmente indiscutível mas juridicamente sem rigor, um princípio que não é direito positivo, em suma, um mau utensílio jurisprudencial. Conclui afirmando que se trata de um não-conceito. (p. 821-830).

Em seguida, David Deharbe desempenha o papel de advogado de defesa e frisa a plasticidade do princípio, ao mesmo tempo que desenvolve a ideia da utilidade política do soft law e expõe o processo de jurisdicização ou "cristalização" do princípio da precaução. Realça a dimensão subversiva do princípio, tanto para a ordem jurídica como para a doutrina jurídica, constatando que uma das suas virtudes intrínsecas é ser capaz de recolocar a eterna questão das condições de produção do Direito. (p. 830-845).

${ }^{38}$ Foi este entendimento que levou Cass Sunstein a escrever Laws of Fear - Beyond the Precautionary Principle. Cambridge University Press, Cambridge 200 e Risk and Reason. Safety, Law and the Environment, University of Chicago Law School, Cambridge University Press, 2002.

${ }^{39} \mathrm{Em}$ Portugal, Vasco Pereira da Silva que critica certos entendimentos mais extremistas do princípio, é de opinião de que "não vale a pena introduzir, pela via da precaução, a irracionalidade no domínio ius-ambiental" "«Mais vale prevenir do que remediar», prevenção e precaução no Direito do Ambiente", in: Direito Ambiental Contemporâneo, Prevenção e Precaução, Juruá Editora, Curitiba, 2009, p.16) Em síntese, a posição do autor é esta: "mais do que proceder à autonomização de uma "incerta" precaução, julgo preferível adoptar um conteúdo amplo para o princípio da prevenção, de modo a incluir nele a consideração tanto de perigos naturais como de riscos humanos, tanto a antecipação de lesões ambientais de carácter actual como de futuro, sempre de acordo com critérios de razoabilidade e bom senso" (idem, p.18).

$4^{40}$ Retomamos aqui a proposta de Hans Jonas (Le principe de responsabilité. Une éthique pour la civilisation technologique, Ed. Champs, Flammarion, Paris, 1999, p.63).

Numa construção mais recente e muito interessante, Catherine Thibierge distingue os "três tempos da responsabilidade" e as três "naturezas da responsabilidade jurídica"

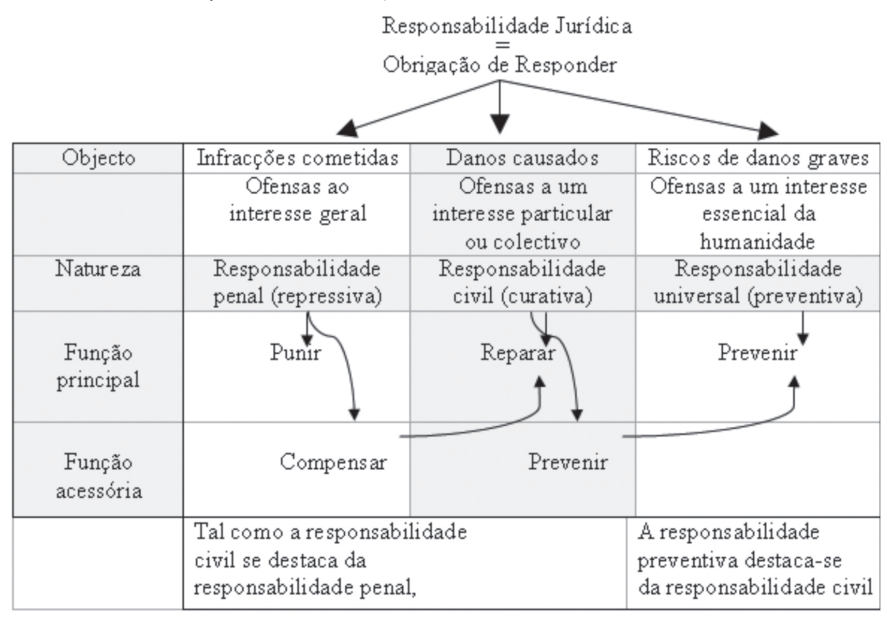

RevCEDOUA 2.2008 
Por outro lado, pensamos também que o princípio da precaução não é um motivo de estagnação ${ }^{42}$ ou bloqueio do desenvolvimento científico ${ }^{43}$ mas, pelo contrário, uma fonte de progresso científico44.

Entendemos ainda que o princípio da precaução não cria insegurança jurídica na gestão do risco. Antes pelo contrário, atenua-a $a^{45}$.

Por fim, consideramo-lo como um princípio de justiça em sentido clássico, na medida em que o princípio da precaução protege sobretudo a parte mais frágil, aqueles que não têm condições de se proteger a si próprios, e responsabiliza quem tem o poder e o dever de controlar os riscos. Num tempo e numa sociedade de riscos, o princípio da precaução contribui determinantemente para realizar a justiça tanto numa perspectiva sincrónica como diacrónica ou, por outras palavras, justiça intrageracional e intergeracional.

É nesta tentativa, de clarificar as condições de recurso ao princípio da precaução - um princípio que veio sem "manual de instruções" - que vamos primeiro começar por analisar os seus pressupostos de aplicação, para examinar, em seguida, o processo de aplicação do princípio.

\section{Pressupostos de aplicação do princípio da precaução}

O princípio da precaução tem-se afirmado por contraposição ao princípio da prevenção que, tanto doutrinal como legalmente, o antecedeu. Na União Europeia, por exemplo, o princípio da prevenção surgiu com força constitucional com o acto Único Europeu, que em 1985 o introduziu no Tratado da Comunidade Económica Europeia, ao lado do Princípio do Poluidor Pagador. Já o princípio da precaução só surgiu em 1992, com o Tratado de Maastricht, da União Europeia, que o colocou antes do princípio da prevenção na lista de princípios constitucionais europeus.

\begin{tabular}{|c|c|c|}
\hline \multicolumn{3}{|c|}{ OS TRES TEMPOS DA RESPONSABILIDADE } \\
\hline Responsabilidade-sanção & Responsabilidade-indemnização & Responsabilidade-antecipação \\
\hline Fundada na culpa & Fundada no risco & Fundada na ameaça de riscos sérios \\
\hline $\begin{array}{l}\text { Centradas no autor, } \\
\text { no comportamento }\end{array}$ & $\begin{array}{l}\text { Centrada na vitima, } \\
\text { no dano }\end{array}$ & $\begin{array}{l}\text { Centrada nas gerações actuais e futuras, } \\
\text { nos seres vivos }\end{array}$ \\
\hline \multicolumn{3}{|l|}{ Séc XIX } \\
\hline & Séc XX & \\
\hline & & Séc. XXI \\
\hline
\end{tabular}

«Avenir de la Responsabilité, Responsabilité de l'Avenir», Le Recueil Dalloz, 4 Mars 2004, nํ9, 7150, p. 582.

${ }_{41}$ Plan B 2.0, Rescuing a Planet Under stress and a Civilization in Trouble, Earth Policy Institute, W.W. Norton \& Company, New York, 2006, p. 17.

${ }^{42}$ Nas palavras de Michel Franc: “Contrariamente ao que se pensa, é mais um princípio de acção do que de inacção. Retomando uma fórmula já usada por outros autores, o princípio da precaução não consiste em erigir como máxima: «na dúvida, abstém-te» mas antes «na dúvida, põe em prática tudo o que te permita agir melhor» («Traitement Juridique du risque et principe de précaution», in: Actualité Juridique Droit Administratif, n.요, 3 Mars, 2003, p.362). ${ }_{43}$ Carla Amado Gomes defende a inoperatividade do princípio da prevenção, numa versão "maximalista" (todas as actuações que, com um grau de possibilidade mínimo, pudessem lesar o ambiente, devem ser evitadas, salvo havendo certeza quase absoluta sobre a sua inocuidade). Assim entendido, o princípio levaria a uma atitude "completamente irrealista, dadas as características da sociedade de risco". Em alternativa, propõe um entendimento, que reduz o princípio da precaução à versão qualificada do princípio da prevenção (A Prevenção à Prova no Direito do Ambiente. Em Especial, os Actos Autorizativos Ambientais Coimbra Editora, 2000, p. 34 e ss).

Mais recente e desenvolvidamente a ideia é retomada em "Risco e Modificação do Acto Autorizativo Concretizador de Deveres de Protecção do Ambiente" (Coimbra Editora, 2007), onde pode ler-se: "Por um lado, porque a precaução é uma noção que comporta riscos graves e atentatórios de valores constitucionais fundamentais. Por outro lado, porque a precaução é um conceito inútil em face das potencialidades e da lógica da prevenção" (p.419).

44 Também Joel Tickner e David Kriebel, reconhecem que o princípio da precaução costuma ser apresentado como sendo contrário à visão científica e inconsistente com decisões baseadas em dados científicos ("The role of Science and Precaution in environmental and publick helath policy", in: Implementing the Precautionary Principle. Perspectives and Prospects, Edward Elgar, Cheltenham, 2008, p.42). 
Embora os princípios da prevenção e da precaução sejam ambos manifestações modernas de uma ideia antiga - de defesa da prudência ambiental e da sustentabilidade, presente, desde sempre, nas grandes culturas e civilizações antigas ${ }^{46}$-, eles distinguem-se, tanto pelas condições de aplicação, como pela natureza das medidas evitatórias que promovem. Entendemos, por isso, que não faz sentido defender o alargamento do princípio de prevenção, a ponto de consumir o princípio da precaução.

Das definições do princípio da precaução, legalmente consagradas no plano interno e no plano internacional, resulta que as condições básicas de recurso ao princípio da precaução são relativamente consensuais.

No plano interno, o princípio surge expressamente definido em três leis principais: na Lei da Água, na Lei de Bases de Protecção Civil e na Lei da Conservação da Natureza e da Biodiversidade:

- Lei da Água (Lei n.ํ5 58/2005, de 29 de Dezembro), artigo 3ํㅜ, n.ํำ e): “Princípio da precaução, nos termos do qual as medidas destinadas a evitar o impacte negativo de uma acção sobre o ambiente devem ser adoptadas, mesmo na ausência de certeza científica da existência de uma relação causa-efeito entre eles".

- Lei de Bases de Protecção Civil (Lei n. .0 27/2006 de 3 de Julho), artigo $5^{\circ}$ c): “O princípio da precaução, de acordo com o qual devem ser adoptadas as medidas de diminuição do risco de acidente grave ou catástrofe inerente a cada actividade, associando a presunção de imputação de eventuais danos à mera violação daquele dever de cuidado".

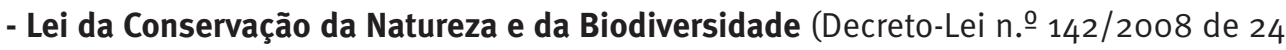
de Julho), artigo $4^{-}$e): "Princípio da precaução, nos termos do qual as medidas destinadas a evitar o impacte negativo de uma acção sobre a conservação da natureza e a biodiversidade devem ser adoptadas mesmo na ausência de certeza científica da existência de uma relação causa-efeito entre eles“.

Também no plano externo olhando para os instrumentos de Direito Internacional em que o princípio da precaução é consagrado, verificamos que nem sempre ele é definido. Não o é, por exemplo, no Tratado da União Europeia. Vejamos alguns instrumentos de Direito Internacional que, de forma mais ou menos clara, definem o princípio:

- Declaração do Rio sobre Ambiente e Desenvolvimento, aprovada durante a Conferência das Nações Unidas sobre Ambiente e Desenvolvimento, em 1992, no Princípio 15: "Para que o ambiente seja protegido, serão aplicadas pelos Estados, de acordo com as suas capacidades, medidas preventivas. Onde existam ameaças de riscos sérios ou irreversíveis não será utilizada a falta de certeza científica total como razão para o adiamento de medidas eficazes em termos de custo para evitar a degradação ambiental”.

\footnotetext{
${ }^{45}$ Acompanhamos, neste ponto, Nicolas de Sadeleer, quando afirma: “num direito pós-moderno, onde a estrutura fortemente hierarquizada das normas foi substituída por uma interacção delicada entre o direito, a ética e a política, este princípio é chamado a preencher uma função crucial: guiar o juiz e a Administração quando pesam os interesses em causa. Longe de exacerbar a insegurança jurídica, o princípio da precaução deve constituir um elemento estável sobre o qual as regulamentações movediças e caóticas podem arrimar-se” ("Les Avatars du Principe de Précaution en Droit Public. Effet de Mode au Révolution Silencieuse?» in: Revue Française de Droit Administratif, 2001, Mai-Juin, p.562).

${ }^{46}$ O Juiz Christopher Gregory Weeramantry (juiz natural do Sri Lanka, membro do Tribunal Internacional de Justiça e Vice-Presidente entre 1997 e 2000), na sua célebre declaração de voto anexa à decisão do Tribunal Internacional de Justiça no caso Gabcíkovo Nagymaros (Acórdão proferido em 1997, no processo instaurado em 1994 pela Hungria contra a Eslováquia, a propósito da construção de um empreendimento hidroeléctrico no rio Danúbio), dá inúmeros exemplos provenientes da Tanzânia, do Irão, da China, do México e, claro, do antigo Ceilão, actual Sri Lanka.
} 
- Convenção das Nações Unidas sobre a Diversidade Biológica, de 1992, (aprovada pelo Decreto $n .-21 / 93$, de 21 de Junho) no parágrafo nono do preâmbulo, frisando que "Quando exista uma ameaça ou redução significativa ou perda de diversidade biológica, a falta de certeza científica não deveria ser razão para adiar medidas para evitar ou minimizar tal ameaça".

- Convenção Quadro das Nações Unidas sobre Alterações Climáticas, de 1992, (aprovada

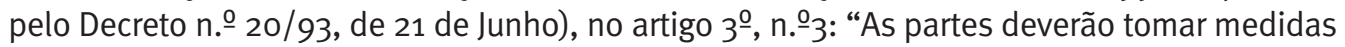
precaucionais para antecipar, prevenir ou minimizar as causas das alterações climáticas e mitigar os seus efeitos adversos. Quando haja ameaças de danos sérios ou irreversíveis, a falta de certeza científica não deveria ser usada como uma razão para adiar tais medidas, tendo em consideração que as políticas e medidas para lidar com as alterações climáticas deveriam ser razoáveis em termos de custos, de forma a garantir benefícios globais ao custo mais baixo possível".

- Convenção de Helsínquia sobre a Protecção e a Utilização dos Cursos de Água Transfronteiriços e dos Lagos Internacionais, concluída a 17 de Março de 1992, (aprovada pelo Decreto n. ${ }^{\circ} 22 / 94$, de 26 de Julho), no artigo $2^{-0}, n .{ }^{-}-5$, a): “O princípio da precaução segundo o qual elas [as partes] não diferem a elaboração de medidas destinadas a evitar que o lançamento de substâncias perigosas que possa ter um impacte transfronteiriço quando a pesquisa transfronteiriça não demonstrou plenamente o elo de causalidade entre essas substâncias, por um lado, e um eventual impacte transfronteiriço, por outro".

- Convenção para a Protecção do Meio Marinho do Atlântico Nordeste ${ }^{47}$, de 1992, (aprovada pelo Decreto n. ${ }^{\circ}$ 59/97, de 31 de Outubro), no artigo 2ํㅡ, n.․ㅡㄹ a): "O princípio de precaução segundo o qual medidas de prevenção devem ser tomadas quando existem motivos razoáveis de preocupação quanto a substâncias ou energia introduzidas, directa ou indirectamente, no meio marinho que possam acarretar riscos para a saúde do homem, ser nocivas para os recursos biológicos e para os ecossistemas marinhos, ser prejudiciais para os valores de recreio ou constituir obstáculo a outras utilizações legítimas do mar, mesmo não havendo provas concludentes de uma relação de causalidade entre esses motivos [no original, inputs] e os efeitos".

- Convenção de Helsínquia sobre a protecção do ambiente marinho do Mar Báltico, de

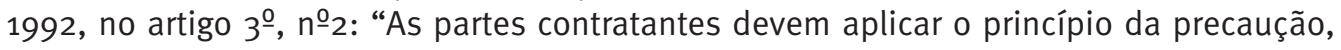
isto é tomar medidas preventivas quando haja razões para admitir que as substâncias ou energia introduzidas, directa ou indirectamente, no ambiente marinho possam criar riscos para a saúde humana, danificar os recursos vivos e os ecossistemas marinhos, danificar os encantos ou interferir com outros usos legítimos do mar mesmo quando não há evidência conclusiva de uma relação causal entre as entradas e os alegados efeitos".

- Protocolo de 1994 à Convenção de 1979 sobre poluição atmosférica a longa distância com vista à redução das emissões de enxofre (ainda não ratificado por Portugal), no parágrafo quatro do preâmbulo: Convencidos de que quando houver ameaças de danos sérios ou irreversíveis, a falta de certeza científica absoluta não deveria se usada como uma razão para adiar tais medidas tendo em consideração que as medidas precaucionais para lidar com as emissões de poluentes atmosféricos devem ser razoáveis em termos de custos".

- Protocolo de Cartagena sobre Biossegurança, de 2000, (aprovado pelo Decreto n.으 7/2004, de 17 de Abril), no artigo 10ํ, n.ㅇ: "A falta de certezas científicas devido à insufici-

$\overline{47}$ Também designada por Convenção OSPAR, resultou da junção e actualização das disposições da Convenção de Oslo, de 1972 sobre deposição de resíduos no mar, e da Convenção de Paris de 1974, sobre fontes de poluição de origem telúrica. 
ência da informação e conhecimento científico relevantes relativos à extensão dos potenciais efeitos adversos, sobre a conservação e uso sustentável da diversidade biológica, de um organismo vivo modificado na Parte importadora, tendo em consideração os riscos para a saúde humana, não deve ser razão para a Parte não tomar uma decisão adequada relativamente à importação do organismo vivo modificado em causa, como referido no parágrafo 3 , supra, com vista a evitar ou minimizar os potenciais efeitos adversos" e no artigo $11^{\circ}$, n.. ㅇ: "A falta de certeza científica devido à insuficiência da informação e conhecimento científico relevantes relativos à extensão dos potenciais efeitos adversos sobre a conservação e uso sustentável da diversidade biológica, de um organismo vivo modificado na Parte importadora, tendo em consideração os riscos para a saúde humana, não deve ser razão para a Parte não tomar uma decisão adequada relativamente à importação do organismo vivo modificado destinado ao uso directo como alimento para pessoas ou ração para animais ou para processamento, com vista a evitar ou minimizar os potenciais efeitos adversos."

- Convenção de Estocolmo sobre Poluentes Orgânicos Persistentes, de 2001, (aprovada pelo Decreto $n-0$ 15/2004, de 3 de Junho) no artigo 8으, n.ㅇำ: “O Comité recomendará, baseado no perfil de riscos referido no parágrafo 6 e na avaliação da gestão de risco referida no parágrafo 7 (a) ou parágrafo 8 , se as substâncias químicas devem ser consideradas pela Conferência das Partes para listagem nos Anexos A, B e/ou C. A Conferência das Partes, tendo em consideração as recomendações do Comité que incluam alguma incerteza científica, decidirá, precaucionalmente, se deve listar as substâncias químicas e suas medidas de controlo específicas nos Anexos A, B e/ou C".

Simplificadamente, o que resulta da análise de todas as consagrações do princípio é que, em matéria ambiental, o princípio da precaução só intervém em situações de riscos ambientais e de incertezas científicas. Nisso se distingue, antes de mais, do princípio da prevenção. Por outras palavras, a precaução destina-se a limitar riscos ainda hipotéticos ou potenciais, enquanto a prevenção visa controlar os riscos comprovados $4^{48}$. Por isso, o princípio da precaução é proactivo, enquanto que o princípio da prevenção é reactivo 49 .

Por outro lado, as medidas precaucionais não são "um fim em si mesmas" ${ }^{\circ}$. E também em razão Gilles Martin, quando defende que, enquanto as acções fundadas no princípio da prevenção têm como finalidade imediata evitar a ocorrência de um dano certo, as acções justificadas pelo princípio da precaução têm um duplo objectivo: «por um lado, evitar imediatamente o "laissez faire" em situações de incerteza legítima; por outro lado, e sobretudo, produzir o conhecimento sobre o risco em causa, seja para dar origem a uma acção preventiva - se a hipótese do risco se verificar - seja para "liberar" a actividade afastando a hipótese de risco» ${ }^{51}$.

Ora, a passagem da "regulação preventiva" para a "regulação precaucional" ${ }^{2}$ dos riscos representa uma mudança de paradigma e exige uma definição muito clara dos pressupostos de intervenção do Estado e dos actores sociais (empresas, organizações não governamentais, cientistas, público em geral).

Em suma, na gestão tradicional do risco exigiam-se provas científicas concludentes, antes de avançar para a regulação de um produto ou actividade envolvendo riscos. 0 princípio da

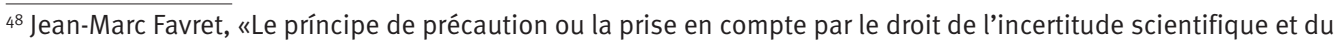
risque virtuel», in: Dalloz, 6 Décembre, 2001, p. 3462.

49 Nancy J. Myers, Carolyn Raffensperger (eds.), Precautionary tools for reshaping environmental policy, the MIT press, Cambridge, Massachusetts, 2006, p. 35.

${ }^{50}$ Cécile Castaing, “La mise en oeuvre du principe de précaution dans le cadre du référé suspension”, in: Actualité Juridique Droit Administratif, nº-43, 15 Décembre 2003, p. 2291.

${ }^{51}$ Gilles J. Martin, “Principe de Précaution, Prévention des Risques et Responsabilité”, in: Actualité Juridique Droit Administratif, n. $\stackrel{0}{40}$, 28 Novembre 2005 , p.2223.

${ }^{52}$ As expressões são de Judith Jones e Simon Bronitt, "The Burden and Standard of Proof in Environmental Regulation: the Precautionary Principle in an Australian Administrative Context”, in: Implementing the Precautionary Principle. Perspectives and Prospects, Edward Elgar, Cheltenham, 2008 p. 145.
} 
precaução, enquanto nova forma de gestão da incerteza, representa uma evolução relativamente à gestão preventiva, em que os actores políticos e os operadores económicos podiam usar e abusar ${ }^{53}$ da divergência persistente entre os cientistas, como uma desculpa para não agi ${ }^{54}$, dando origem àquilo que se designa por "parálise pela análise" 55 . Pelo contrário, a gestão precaucional implica a regulação urgente de riscos hipotéticos, ainda não comprovados.

Sabendo que os pressupostos fundamentais de aplicação do princípio da precaução são a existência de riscos ambientais e a incerteza científica quanto aos riscos, vamos analisá-los sucessivamente.

\subsection{Primeiro pressuposto: os novos riscos}

Já vimos que na gestão antecipatória dos "novos riscos"56 não podemos "dar-nos ao luxo de esperar e verificar que estamos errados" 57 . Os riscos são importantes de mais e as consequências graves de mais para ficarmos à espera das provas irrefutáveis e do consenso científico geral, em torno delas.

Segundo Joren van der Sluijs e Wim Turkenburg, a partir de agora, devemos "pensar o impensável” imaginando e construindo cenários de ocorrências ambientais indesejáveis futuras, mesmo pouco prováveis ${ }^{58}$.

\footnotetext{
${ }_{53}$ René von Schomberg, "The Precautionary Principle and its Normative Challenges, in: Implementing the Precautionary Principle. Perspectives and Prospects, Edward Elgar, Cheltenham, 2008, p.23.

${ }_{54}$ Sobre o dever de decidir, ver o estudo de Sérvulo Correia sobre "O Incumprimento do Dever de Decidir", in: Estudos Jurídicos e Económicos em Homenagem ao Prof. Doutor António de Sousa Franco, vol II, Coimbra Editora, 2006, p. $217-254$.

${ }^{55}$ Da expressão em língua inglesa, paralisis through analisis. Micharel More analisa o adiamento ("delay”), por razões ideológicas ou políticas, como ferramenta política nos processos de decisão. 0 adiamento ocorre nos processos que envolvam uma "alteração da ordem instituída" mas em que se receie o resultado dessa alteração ou em que haja uma oposição conceptual dos decisores, à alteração. O método mais comum de adiamento é o excesso de consulta pública (“Political Practice: Uncertainty, Ethics and Outcomes”, in: Uncertainty and Risk. Multidisciplinary Perspectives, Earthascan, London, 2008, p. 179). Por isso, o tempo para resolver as incertezas é ou deve ser limitado por lei. Judith S. Jones, (“Certainty as Illusion: The Nature and Purpose of Uncertainty in the Law", in: Uncertainty and Risk. Multidisciplinary Perspectives, Earthascan, London, 2008, p. 277).

${ }^{56} \mathrm{~A}$ expressão é de Kerry H. Whiteside em Precaucionary Politics. Principle and Practice in Confronting Environmental Risk, Massachusetts Institute of Technology”, 2006. p. 30.

${ }^{57}$ A afirmação é da Comissão Europeia no Quinto Programa de Acção em Matéria de Ambiente e Desenvolvimento Sustentável, em vigor no período 1993-2000, aprovado por uma Resolução do Conselho e dos representantes dos Governos dos Estados-membros, reunidos no Conselho, em 1 de Fevereiro de 1993.

58 "Climate Change and the precautionary principle", in: Implementing the Precautionary Principle. Perspectives and Prospects, Edward Elgar, Cheltenham, 2008 p. 262.

${ }_{59}$ Stephen Dovers identifica as "características dos problemas políticos que tornam difícil a escolha das políticas de resposta:

- escalas espaciais e temporais alargadas, aprofundadas e altamente variáveis;

- possibilidade de existência de limites ecológicos absolutos às actividades humanas;

- complexidade dos problemas e conexões entre problemas;

- risco difuso e incerto, frequentemente não susceptível de análise probabilística;

- efeitos irreversíveis;

- impactes cumulativos e não descontínuos;

- novas dimensões morais (por exemplo, outras espécies, gerações futuras);

- causas sistémicas, embutidas em padrões de produção, consumo, ocupação do território e governança;

- valores ambientais importantes não transaccionados em mercados formais, e portanto sem um valor monetário atribuído;

- dificuldade em separar custos e benefícios públicos e privados;

- falta de aplicação ampla de instrumentos de política e falta de abordagens de gestão;

- falta de definição de políticas, direitos de gestão e de propriedade, de papéis e de responsabilidades;

- necessidade de conhecimentos integrados/interdisciplinares;

- solicitações intensas de participação da comunidade na formulação e na gestão das políticas; e

- novidade absoluta na sequência dos problemas de política".

("Precautionary policy assessment for sustainability", in: Implementing the Precautionary Principle. Perspectives and Prospects, Edward Elgar, Cheltenham, 2008, p.90.)
} 
O princípio da precaução destina-se, sobretudo, a regular os chamados "novos riscos" 59 ambientais que se caracterizam por ser riscos globais, retardados e irreversíveis.

Por serem globais e irreversíveis mas, na maior parte dos casos, riscos futuros, que afectarão gerações que ainda não nasceram, é que o princípio da precaução é um princípio de justiça na sua acepção mais clássica ${ }^{60}$. Já na Declaração de Direitos do Homem e do Cidadão, de 1789 , se proclamava que "a liberdade consiste em poder fazer tudo o que não prejudique o próximo" ${ }^{61}$. Neste caso, o próximo são as gerações futuras.

\subsubsection{Riscos globais}

Os riscos globais são riscos em larga escala, com magnitudes sem precedentes, abrangendo vastas regiões do Planeta.

As acções conjugadas da evolução científica e tecnológica e da intensificação da produção industrial e agrícola, com a aceleração do consumo e a a globalização do mercado dos produtos e serviços, conduzem a uma massificação dos riscos, que se tornam riscos planetários. Por isso, a necessidade de convocar a aplicação do princípio da precaução é também mais frequente agora $^{62}$. Mas isso não significa que, nos séculos passados, não tenha havido produtos ou tecnologias que justificassem o recurso a este princípio, se ele já tivesse sido conjecturado nessa altura. Se existem exemplos de avanços científicos e tecnológicos em que os riscos não se concretizaram, e dos quais estamos actualmente a usufruir as vantagens (como os antibióticos, as vacinas, a energia eléctrica ou os transportes aéreos), há também catástrofes passadas, dentro e fora do âmbito ambiental, cujas consequências ainda hoje estamos a gerir: os casos do sindroma de envenenamento por mercúrio na Baía de Minamata desde a década de 50, da contaminação radioactiva de Chernobil em 1986, dos lotes de sangue contaminado com Sida administrado a doentes em França, no início da década de 90, da encefalopatia espongiforme bovina no Reino Unido no mesmo período, das marés negras do Erika, em França, em 1999 e do Prestige, em Espanha, em 2002, são apenas alguns exemplos.

\subsubsection{Riscos retardados}

Riscos retardados são aqueles que se desenvolvem lentamente, ao longo de décadas ou séculos, que levam gerações a materializar-se, mas que assumem, a certa altura, dimensões catastróficas em virtude da extensão e da irreversibilidade. Este padrão de crescimento toma a designação de "crescimento exponencial". É um padrão que muitos fenómenos (naturais e sociais) apresentam e que, por isso, torna urgente a adopção de medidas precaucionais. Malthus foi o primeiro a escrever sobre este padrão de crescimento em relação às populações, com a publicação, em 1798, da obra An essay on the principles of population as it affects the future improvement of society ${ }^{63}$. Mais recentemente, e no âmbito ambiental, o impressionante efeito do crescimento exponencial foi notavelmente ilustrado por uma charada citada por Donella e Denis Meadows e Jorgen Rangers: «suponhamos que se tem um lago em que cresce um nenúfar. 0 nenúfar duplica de tamanho todos os dias. Se deixasse a planta crescer livremente, ela cobriria completamente o lago em trinta dias, provocando a morte de

\footnotetext{
${ }^{60}$ Recordando a trilogia de Ulpianus ("Iuris praecepta sunt haec: honeste vivere, alterum non laedere, suum cuique tribuere”. [Ulpiano, Digesta 1.1.10.1; Institutiones 1.1.3]) o princípio da precaução visa dar cumprimento ao "alterum non laedere" (sendo que o alterum corresponde agora a um outro mais alargado, que abrange também as gerações futuras).

61 - Art. 4.ํㅡ A liberdade consiste em poder fazer tudo o que não prejudique o próximo: assim, o exercício dos direitos naturais de cada homem não tem por limites senão aqueles que asseguram aos outros membros da sociedade 0 gozo dos mesmos direitos. Estes limites apenas podem ser determinados pela lei.

${ }^{62}$ Por exemplo: só recentemente, com a intensificação do tráfego aéreo, se tornou evidente o risco das erupções vulcânicas para a navegação aérea.

${ }^{63}$ Disponível online em versão integral, através da Library of Economics and Liberty da Fundação Liberty Fund, instituída em 1960, na América, por Pierre Goodrich (http://www.econlib.org/library/Malthus/malPlong.html).
} 
todas as outras formas de vida aquática. Durante muito tempo o nenúfar parece pequeno, por isso você resolve não se preocupar com ele enquanto não ocupar metade do lago. Em que dia acontecerá isso?» A resposta é, à primeira vista, surpreendente: «No vigésimo nono dia. Fica-lhe só um dia para salvar o lago ${ }^{64}$. Esta é a razão da premência de uma actuação precaucional: evitar enfrentar a magnitude do problema no penúltimo dia...

Desde a desertificação à eutrofização dos rios, desde a extinção de espécies à produção de resíduos, exemplos não faltam, pois, na Natureza, o crescimento exponencial verifica-se aos mais diversos níveis.

\subsubsection{Riscos irreversiveis}

Riscos irreversiveis são aqueles que, se se concretizarem, terão consequências permanentes ou, pelo menos, tão duradouras que podemos considerá-las irreversíveis à escala humana .

A novidade, e relativa complexidade, da ideia de riscos irreversíveis justifica que the dediquemos mais algum tempo da nossa atenção.

A irreversibilidade é um aspecto fulcral da caracterização dos riscos, que comporta, para as gerações futuras, perda de oportunidades de realização. A defesa de certas irreversibilidades justifica-se, portanto, pelo interesse na "manutenção das escolhas potenciais para o presente e para o futuro" 65 .

Mas a irreversibilidade significa apenas "a impossibilidade de retornar ao passado", por isso, "uma irreversibilidade não é, em si mesma, nem boa nem má; ela é neutra”66.

As irreversibilidades positivas já existem em leis aprovadas para preservar valores arqueológicos, artísticos, culturais ou paisagísticos, considerados património municipal, nacional ou até da humanidade. Agora trata-se de reconhecer que a importância de certos valores genéticos, biológicos ou ecológicos também justifica a proibição da sua destruição e o estabelecimento de uma irreversibilidade ambiental positiva.

$\mathrm{Na}$ análise das irreversibilidades, Alexandre Kiss ${ }^{67}$ fala em irreversibilidades negativas e irreversibilidades positivas. As irreversibilidades negativas seriam "evoluções destrutivas irreversíveis", ou seja, riscos que, se se concretizarem, se transformam em danos definitivos. 0 exemplo paradigmático é a extracção de recursos não renováveis até à exaustão ou a exploração de recursos renováveis para lá da capacidade de renovação. Mas nem todas as irreversibilidades estão ligadas à conservação da natureza. Outro exemplo é a lei sobre armazenagem de resíduos radioactivos em França, que obriga a que eles devem ser guardados de forma a poderem ser recuperados, um dia, quando o progresso dos conhecimentos científicos já permita neutralizá-los ${ }^{68}$.

No entanto, a irreversibilidade, como alerta Cass Sunstein, deve ser correctamente entendida: "não há uma linha a separar claramente a reversibilidade da irreversibilidade. Há um continuum e não uma dicotomia. A questão não é saber se um efeito pode ser revertido, mas a que custo" ${ }^{69}$.

Se por um lado podemos aceitar a ideia de Sunstein, concordando que a irreversibilidade até pode ser um conceito gradual, por outro lado não podemos deixar de admitir que há um

\footnotetext{
${ }^{64}$ Além dos limites. Da catástrofe total ao futuro sustentável, Difusão Cultural, Lisboa, 1993. p. 18 e 19.

${ }_{65}$ Martine Rèmond-Gouilloud, «L'Irreversibilité: de l'Optimisme Dans l'Environnement», in: Révue Juridique de l'Environnement, numéro spécial, 1998, p. 17.

${ }^{66} / \mathrm{dem}$, p. 9.

${ }^{67}$ Alexandre Kiss, “L'Irreversibilité et le Droit des Generations Futures”, in: Révue Juridique de l'Environnement, numéro spécial, 1998, p. 52.

${ }^{68}$ Michel Prieur explora desenvolvidamente as vantagens e os inconvenientes da deposição definitiva de resíduos radioactivos («L'irreversibilité et la Gestion des Déchets Radioactifs dans la Loi du 30 Décembre 1991», in: L'irreversibilité, Revue Juridique de l'Environnement, no spécial, 1998, p. 125).

${ }^{69}$ Worst Case Scenarios, Harvard University Press, Cambridge, 2007, p. 183. Exemplificando os graus de dificuldade de reversão com a decisão de casar ou não casar, Sunstein nota que um casamento pode ser revertido, mas o divórcio raramente é fácil” (op. cit., p. 176).
} 
limiar, a partir do qual a irreversibilidade se torna incontestável. Citando Martine RèmondGouilloud, podemos admitir que há "irreversibilidades certas e incertas" ${ }^{\circ}$. Por isso, o princípio da precaução prescreve que há certos limiares que não podem ser ultrapassados para que não se materializem as irreversibilidades ambientais negativas certas. 0 contrário de irreversibilidade não é, portanto, a reversibilidade, mas a durabilidade dos recursos bióticos e abióticos, o respeito dos processos e dos ecossistemas, numa palavra, a sustentabilidade. Por alguma razão, durabilidade e sustentabilidade são sinónimos em língua francesa.

Mas a irreversibilidade, que consta da definição constitucional e legal ${ }^{71} \mathrm{em}$ França, e também do Protocolo de 1994 à Convenção de 1979 sobre poluição atmosférica a longa distância com vista à redução das emissões de enxofre, é um elemento omisso no Direito português.

Recordemos o artigo $5^{\circ}$ da Charte de l'Environnement: "Quando a realização de um dano, se bem que incerto, no estado actual dos conhecimentos científicos, possa afectar de maneira grave e irreversível o ambiente, as autoridades públicas velam, por aplicação do princípio da precaução, e no seu domínio de atribuições, pela aplicação de procedimentos de avaliação dos riscos e pela adopção de medidas provisórias e proporcionadas a fim de evitar a realização do dano"72. Em França, só o dano que além de incerto, é também grave e irreversível, é que suscita a aplicação do princípio da precaução. Ou seja: enquanto no Direito francês, a irreversibilidade é um elemento que acresce à gravidade, no Direito português - onde não encontramos referências autónomas à irreversibilidade - ela é apenas um critério, entre outros, de gravidade. Em Portugal nada parece indicar que haja um estatuto jurídico mais forte da irreversibilidade, enquanto pressuposto de aplicação do princípio da precaução. Na prática, a diferença está em que, em Portugal, um dano ambiental pode não ser irreversível e convocar, mesmo assim, o princípio da precaução, desde que seja grave em função da magnitude, extensão, complexidade, etc..

Mas isso não significa que a irreversibilidade não seja relevante e não deva ser tida em consideração no ordenamento jurídico português. Significa apenas que ela não é um elemento autónomo na qualificação do risco. Indo ainda mais longe, com base nas consagrações legais do princípio no nosso ordenamento jurídico, verificamos que parece prescindir-se da irreversibilidade e mesmo da gravidade do dano, bastando a incerteza científica para convocar a aplicação do princípio. Esta interpretação é válida pelo menos em matérias ambientais, nomeadamente na conservação da natureza e biodiversidade (Decreto-lei n. ${ }^{\circ}$ 142/2008, de 24 de Julho) e na protecção de águas (Lei n. $.58 / 2005$, de 29 de Dezembro), mas logicamente também em matéria de gestão de resíduos, controlo da poluição atmosférica, prevenção de ruído, mitigação das alterações climáticas, etc., mas já não quanto à protecção civil).

\footnotetext{
${ }^{70}$ «L'Irreversibilité: de l’Optimisme Dans l'Environnement», in: Révue Juridique de l'Environnement, numéro spécial, 1998, p. 12. Também Agnès Michelot considera que “o princípio da precaução traduz a tomada em consideração da irreversibilidade incerta” (“Utilization durable et irreversibilité(s). Du «jeu» de la temporalité aux enjeux de la durabilité», in: Révue Juridique de l'Environnement, numéro spécial, 1998, p.36).

${ }^{71}$ Artigo 110, II, $1^{\circ}$ do Código do Ambiente: «o princípio da precaução, segundo o qual, a falta de certezas, considerando os conhecimentos científicos e técnicos do momento, não devem retardar a adopção de medidas efectivas e proporcionadas visando prevenir o risco de danos graves e irreversíveis ao ambiente a um custo economicamente aceitável".

${ }^{72}$ A doutrina francesa nota que o princípio da precaução foi o único que se manteve na Charte de l'Environnement enquanto princípio. Diferentemente, os princípios da prevenção e do poluidor pagador ganharam uma formulação mais densa, e transformaram-se em normas constantes, respectivamente, do Artigo 3 (todos devem, nas condições definidas na lei, prevenir as ofensas ao ambiente que sejam susceptíveis de causar ou, subsidiariamente, limitar as suas consequências") e do Artigo $4^{0}$ (Todos devem contribuir para a reparação dos danos que causam ao ambiente, nas condições definidas na lei"). No entanto, Olivier Godard, (em "The Precautionary Principle and Catastrophism on tenterhooks: lessons from a constitutional reform in France”, in: Implementing the Precautionary Principle. Perspectives and Prospects, Edward Elgar, Cheltenham, 2008, p. 78) defende que 0 artigo $5^{\circ}$ da Carta do Ambiente, em França é o único que tem efeito directo, podendo ser invocado em Tribunal sem necessidade de leis e regulamentos adicionais que o tornem aplicável. Em 2003 a Revue Juridique de l'Environnement dedicou um número especial ao ambiente na Constuição: La Charte Constitutionnelle en Débat.
}

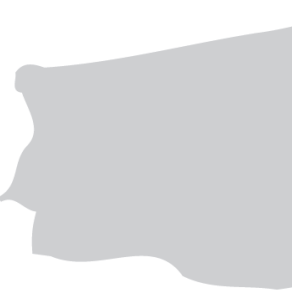


Mas esta interpretação maximalista do princípio da precaução é muito criticável por facilitar excessivamente o recurso a um instrumento, cuja utilização permite a adopção de medidas bastante gravosas de restrição da iniciativa económica, em situações de incerteza científica, devendo, por isso, ser excepcional.

A solução passa por fazer uma interpretação correctiva das condições de recurso ao princípio da precaução, à luz das definições consagradas fora do país, adoptando os requisitos uniformemente exigidos no direito internacional, os quais se reconduzem à exigência alternativa de, pelo menos, uma das características do dano potencial: gravidade ou irreversibilidade. Assim, para aplicação do princípio da precaução, basta que o risco seja grave, mesmo que não seja irreversível; ou que seja irreversível, mesmo que não seja muito grave. Nunca apenas um dano incerto.

\subsection{Exemplos}

Os exemplos de riscos globais, irreversíveis e retardados ${ }^{73}$, infelizmente, não são poucos ${ }^{74}$, e o seu reconhecimento como problemas ambientais graves faz com que beneficiem de regulação à escala internacional.

1. OS CFC 75

O clorofluorcarbono - CFC - (gás usado comercialmente desde a década de 50, como solvente orgânico, como refrigerante e como propulsor, em extintores de incêndios e aerossóis), é um exemplo perfeito de um risco global. O buraco da camada do ozono (confirmado cientificamente na década de 80 , embora se especulasse sobre a sua existência desde a década de 70), localizado sobre o hemisfério Sul, resultou da emissão de grandes quantidades deste gás - CFC - , sobretudo no hemisfério Norte. É um risco planetário. Por outro lado, após a sua emissão para a atmosfera, as partículas de CFC não só não desaparecem como perduram ao longo de décadas ${ }^{76}$, durante as quais o efeito de fotólise produz reacções em cadeia, destruidoras do ozono atmosférico. Também por isso pode ser considerado um risco retardado.

\section{Os POP77}

Riscos globais e retardados são também os efeitos dos poluentes orgânicos persistentes - $\mathrm{POP}^{78}$ - que existem no ambiente, em concentrações da ordem dos microgramas ou nanogramas, que são desreguladores endócrinos, e actuam por bio-acumulação, no orga-

\footnotetext{
73 Rosie Cooney também avança alguns exemplos, distinguindo entre a aplicação do princípio em "cenários verdes" - associados à conservação da natureza e à protecção da biodiversidade - e em "cenários castanhos" - ligados às políticas de prevenção da poluição em meio industrial ou urbano - ("A Long and Winding road? Precaution from Principle to Practice in Biodiversity Conservation", in: Implementing the Precautionary Principle. Perspectives and Prospects, Edward Elgar, Cheltenham, 2008 p. 229).

74 Para uma discussão detalhada de catorze exemplos de temas que, pelas suas características, convocam o princípio da precaução, ver a obra editada pela Agência Europeia do Ambiente Late Lessons from Early Warnings: the Precautionary Principle 1896-2000, Copenhagen, 2001, p. 17 a 192.

75 Regulados pela convenção de Viena para a Protecção da Camada de Ozono, de 1985 (aprovada pelo Decreto do Governo n.ำ 5/88, de 9 de Abril), e pelo Protocolo de Montreal sobre as Substâncias que Empobrecem a Camada de Ozono de 1987 (aprovado pelo Decreto n.. 20/88, de 30 de Agosto. A alteração ao Protocolo, de Dezembro de 1999, foi aprovada pelo Decreto $\mathrm{n} . \stackrel{0}{9}$ /2006 de 23 de Janeiro).

${ }^{76} \mathrm{O}$ tempo de vida dos CFC na atmosfera varia entre 40 a 80 anos para o CFC-11, e os 75 a 150 anos para o CFC-12.

77 Regulados pela Convenção de Estocolmo sobre Poluentes Orgânicos Persistentes, de 2001, aprovada pelo Decreto n- $15 / 2004$ de 3 de Junho.

${ }^{78}$ Alguns são usados na agricultura como biocidas (é o caso do DDT, da aldrina, da endrina, da dieldrina, do clordano, do heptacloro, do hexaclorobenzeno, etc.), outros são usados em diversas aplicações industriais (como PCB usado em condensadores, transformadores, e líquidos refrigeradores) e outros são emitidos em processos de produção industrial (dioxinas, furanos).
} 
nismo dos seres vivos, sendo transmitidos, com graus de concentração crescente, ao longo da cadeia alimentar.

\section{OS GEE'9}

Também o fenómeno dos gases com efeito de estufa - GEE - é um exemplo de um risco global e irreversível à escala humana. A interferência humana no clima é estudada cientificamente desde a década de 60 , mas apenas na década de 90 se conseguiu reunir um consenso científico, quanto às alterações climáticas e à influência dos GEE no aquecimento global.

\section{Os OGM ${ }^{80}$}

Os organismos geneticamente modificados - OGM - representam um exemplo de escola de riscos retardados, irreversíveis e potencialmente globais. A libertação no ambiente de OGMs, pela utilização agrícola de variedades vegetais geneticamente modificadas, comporta riscos de poluição genética, contaminação de espécies agrícolas convencionais pelos genes modificados. A contaminação, que pode ocorrer por processos naturais como polinização ou ventos fortes, pode afectar geneticamente as espécies, pondo em perigo os equilíbrios ecológicos e a diversidade biológica.

\section{As radiações ionizantes ${ }^{81}$}

Outro exemplo flagrante são os riscos nucleares, riscos que, além da dimensão potencialmente global, envolvem uma escala temporal de tal modo longa, que permite qualificá-los como riscos irreversíveis. A explosão e fusão do reactor nuclear de Chernobil, a maior catástrofe tecnológica da história da humanidade, provocou a libertação de césio, xénon, iodo e outros materiais radioactivos em quantidades maciças ${ }^{82}$, afectando milhões de pessoas numa área territorial alargada ${ }^{83} \mathrm{e}$ dando origem à criação de uma "reserva radioactiva" com $30 \mathrm{~km}^{2} \mathrm{em}$ torno do reactor, onde é previsível que os níveis de radioactividade se mantenham elevados durante milhares de anos.

\section{As extinções de recursos bióticos ${ }^{84}$.}

Um exemplo de riscos mais retardados e menos visíveis, mas com efeitos também potencialmente catastróficos, são a extinção de espécies da fauna, nomeadamente da fauna piscícola em virtude da sobrepesca ${ }^{85}$ e a extinção de espécies piscícolas ${ }^{86}$ Outro exemplo, mas

\footnotetext{
79 Regulados pela Convenção-Quadro das Nações Unidas sobre Alterações Climáticas, de $1992^{79} \mathrm{e}$ o Protocolo de Quioto de 1997, aprovada pelo Decreto $\mathrm{n}^{-}{ }^{7}$ //2002 de 25 de Março.

${ }^{80}$ Regulados pela Convenção das Nações Unidas sobre a Diversidade Biológica, de 1992 (aprovada pelo Decreto n. $.921 / 93$, de 21 de Junho) e pelo Protocolo de Cartagena sobre Biossegurança, de 2000 (aprovado pelo Decreto ก. $.9 / 2004$, de 17 de Abril).

${ }^{81}$ Reguladas pela Convenção de Londres para a Prevenção da Poluição Marinha Causada por Operações de Imersão de Detritos e Outros Produtos, de 1972 (aprovada pelo Decreto n.․ㅜ 33/88 de 15 de Setembro), pela Convenção de Viena sobre Notificação Rápida em caso de Acidente Nuclear, de 1986 (aprovada pela Resolução da Assembleia da República nํㅜ 22/92 de 2 de Abril), pela Convenção de Viena sobre Assistência em Caso de Acidente Nuclear ou Emergência Radiológica, de 1986 (Aprovada pela Resolução da Assembleia da República n.. 72/2003, de 12 de Setembro), e pela Convenção Conjunta de Viena sobre a Segurança da Gestão do Combustível Usado e a Segurança da Gestão dos Resíduos Radioactivos, de 1997, (aprovada pelo Decreto no 12/2009 de 21 de Abril).

${ }^{82}$ Estima-se que a magnitude tenha sido equivalente a 400 bombas de Hiroshima.

${ }^{8} 160000 \mathrm{~km} 2$ foram oficialmente declarados como tendo sido afectados por esta catástrofe.

${ }^{84}$ Reguladas pela Convenção de Ramsar sobre Zonas Húmidas de importância internacional, de 1971 (aprovada pelo Decreto n.ำ101/80, de 9 de Outubro), pela Convenção de Washington sobre o Comércio Internacional de Espécies da Fauna e da Flora Selvagem Ameaçadas de Extinção, de 1973 (aprovada pelo Decreto n.ํ50/80, de 23 de Julho) e pela Convenção de Berna sobre a Vida Selvagem e os Habitats Naturais na Europa, de 1979 (aprovada pelo Decreto 95/81, de 23 de Julho).

${ }^{85}$ Pesca excessiva, além do que é sustentável em termos de reposição do equilíbrio populacional da espécie.

${ }^{86}$ Michel Landis, em "Fate, Responsability and "Natural” Disaster Relief: Narrating the American Welfare State", (in:
} 
agora de extinção de espécies da flora e de habitats é a desflorestação, com a consequente perda de biodiversidade, erosão, secagem dos aquíferos, desertificação, desaparição dos recifes de coral, etc. Veja-se a impressionante descrição dos efeitos em cadeia da desflorestação no arquipélago das Filipinas, no caso Oposa vs. Factoran que em 1993 foi julgado no Supremo Tribunal, em Manila ${ }^{87}$.

\section{As alterações do regime hidrológico ${ }^{88}$}

0 caso da desaparição incontrolável e iminente do mar Aral, entre o Cazaquistão e o Uzbequistão ${ }^{89}$ é o modelo, por excelência, de um risco retardado. A catastrófica transformação do mar Aral num deserto salgado é perfeitamente conhecida desde há décadas e a sua evolução pode ser apreciada, por comparação das imagens obtidas a partir do espaço, desde as primeiras missões lunares, com as actuais imagens de satélite, onde é bem perceptível o pouco que resta dele.

Fenómenos similares ocorrem noutras partes do mundo, sendo alguns dos exemplos mais significativos a redução da superfície do lago Chad (fazendo fronteira entre a Nigéria, o Chade e os Camarões) ou a desaparição dos glaciares na Patagónia.

Perante exemplos tão expressivos, questionamo-nos sobre se não haverá casos menos extremos mas que convoquem igualmente o princípio da precaução. Quão importante deve ser o risc $0^{90}$ para que se justifique convocar o princípio da precaução?

\subsection{A gravidade relevante}

Doutrinalmente, são avançados vários critérios de gravidade dos riscos. Nancy J. Myers e Carolyn Raffensperger ${ }^{91}$ apontam os seguintes: risco de danos não reversíveis (uma perda irreparável de biodiversidade ou funções do ecossistema), risco de dano alargado (impactes que se estendem para lá das fronteiras agrícolas, biológicas ou políticas), risco de danos cumulativos (acumulação ou exacerbação de riscos ambientais já existentes), risco de danos involuntários (sem consulta, notificação ou escolha por parte das vítimas); risco de danos injustamente distribuídos (quem suporta os riscos não é quem beneficia das vantagens); e risco potenciador (susceptível de provocar danos em cadeia).

Law and Society Review, vol 33, n. $\underline{0}_{2}$ 1999, p. 263), compara o pedido de ajuda dos pescadores ao governo pelas dificuldades crescentes da faina em virtude da escassez de peixe, ao criminoso, que mata os pais, e depois pede clemência ao juiz porque é órfão.

${ }^{87}$ Caso celebrizado por Alexandre Kiss em vários dos seus escritos e que se encontra disponível na íntegra em http://www.lawphil.net.

${ }^{88}$ Regulado pela Convenção de Montego Bay sobre Direito do Mar, de 1982 (aprovada pela Resolução da Assembleia da República n.ำ 60-B/97, de 14 de Outubro) e pela Convenção de Helsínquia sobre a Protecção e a Utilização dos Cursos de Água Transfronteiriços e dos Lagos Internacionais, de 1992 (aprovada pelo Decreto n. ${ }^{\circ}$ 22/94, de 26 de Julho).

89 Para combater o fenómeno foi criado, em 1993, um Fundo Internacional para Salvar o Mar Aral (The International Fund for Saving the Aral Sea (IFAS), integrando representantes do Cazaquistão, Tadjiquistão, Turquemenistão e Quirguistão.

${ }^{90}$ A Comissão Europeia, na sua decisão de 2000, identifica e descreve alguns momentos autónomos do processo de avaliação do risco:

1. Identificação do perigo. O perigo é aqui corporizado nos agentes biológicos, químicos ou físicos potencialmente responsáveis pelo dano;

2. Caracterização do perigo. Determinação quantitativa e qualitativa da natureza e gravidade dos efeitos de um produto ou actividade.

3. Avaliação da exposição. Esta avaliação equivale à vulnerabilidade dos receptores. As cartas de riscos de inundação, onde se identificam os valores susceptíveis de serem afectados pelas inundações, são instrumentos de avaliação da exposição

4. Caracterização do risco (espécie de declaração conclusiva sobre a importância do risco), que resulta da consideração e devida ponderação da probabilidade, com a natureza e a dimensão dos efeitos e com a vulnerabilidade.

${ }_{91}$ Precautionary tools for reshaping environmental policy, the MIT press, Cambridge, Massachusetts, p. 39 e 40. 
Legalmente, é no regime jurídico da avaliação de impacte ambiental de projectos que encontramos critérios densificadores do conceito de riscos importantes.

Estes critérios foram consagrados no anexo III da Directiva 85/337, de 27 de Julho92, e destinam-se a auxiliar o legislador nacional na definição de limiares e condições de sujeição a avaliação de impacte ambiental, aplicáveis às categorias de projectos constantes da lista anexa II, mas também como auxiliares da administração, na selecção de outros projectos (diferentes dos constantes da lei) a sujeitar à avaliação de impactes. Por esta razão os mesmos critérios foram transcritos para o nosso ordenamento jurídico aquando da transposição da Directiva pelo Decreto-lei n. $069 / 2000$, de 3 de Maio (alterado e republicado pelo Decreto-lei n. $.197 / 2005$ de 8 de Novembro) e incluídos como anexo V93.

Embora os critérios se apliquem originalmente apenas aos riscos antrópicos decorrentes de projectos (entendidos como "obras de construção ou de outras intervenções no meio natural ou na paisagem, incluindo as intervenções destinadas à exploração de recursos naturais"94), não nos parece excessivo defender a sua aplicação analógica aos riscos naturais ou semi-naturais.

Vamos, por isso, proceder à análise dos referidos critérios de selecção, tendo em mente os diferentes tipos de riscos, naturais, antrópicos e mistos. Da leitura do anexo $\mathrm{V}$, em que estão consagrados, resulta que os critérios legais de gravidade se encontram organizados em três categorias: critérios que resultam das características dos projectos, critérios ligados à localização e critérios relativos aos impactes ambientais dos projectos.

\subsubsection{Características dos projectos}

As características dos projectos são o primeiro elemento a ter em consideração na submissão ou não de um projecto a AIA. Assim, relativamente à caracterização do projecto (ou do fenómeno natural), tomam-se em consideração a dimensão, a natureza e a localização.

A natureza do projecto ou fenómeno natural ajuda a compreender a intensidade de utilização de recursos naturais, os impactes resultantes da produção de resíduos, poluição e incómodos, o risco de acidentes, e os efeitos cumulativos relativamente a outros projectos ou fenómenos naturais.

Ou seja, um projecto grande, que usa muitos recursos naturais, que produz muitos resíduos, que gera muita poluição, que utiliza substâncias e tecnologias perigosas, e que se situa junto a instalações semelhantes, será sempre um projecto muito incómodo, em termos de impactes ambientais, independentemente da sua localização. Se algum dos impactes forem incertos, podemos convocar a aplicação do princípio da precaução.

Pelo contrário, em relação a um projecto de pequena dimensão, que usa poucos recursos naturais, que produz poucos resíduos, gera pouca poluição, não utiliza substâncias ou tecnologias que possam considerar-se perigosas, que está isolado de outras instalações, e, sobretudo, que não se localiza numa zona sensível, dificilmente justificará a invocação do princípio da precaução, mesmo que subsistam incertezas.

\subsubsection{Localização dos projectos}

A localização em zonas ecológica ou humanamente sensíveis é um dos mais importantes critérios de submissão a avaliação de impacte ambiental e uma das formas mais eficazes de prevenir a ocorrência de impactes indesejáveis.

\footnotetext{
$\overline{9_{2}}$ Alterada pela Directiva 97/11/CE, de 3 de Março, e pela Directiva 2003/35/CE, de 26 de Maio.

${ }_{93}$ Que incluímos no final ao presente trabalho como anexo.

${ }^{94}$ Artigo $2^{0}$ o) do Decreto-lei n. ${ }^{\circ}$ 69/2000.
} 
Quanto à localização em zonas ecologicamente sensíveis, releva sobretudo a afectação do solo, a riqueza, a qualidade e a capacidade de regeneração dos recursos naturais e a capacidade de absorção do ambiente natural. Considerando este critério, são consideradas, em abstracto, como sensíveis, as seguintes zonas naturais: zonas húmidas, zonas costeiras, zonas montanhosas e zonas florestais.

São ainda sensíveis as zonas já legalmente reconhecidas como importantes. É o caso das reservas e parques naturais, das zonas de protecção especial das aves selvagens, dos sítios da Rede Natura 2000, e de outras zonas classificadas ou protegidas por lei. Dentro dos sítios da Rede Natura 2000, alguns habitats são considerados como especialmente carecidos de protecção: são os habitats prioritários, ou seja, aqueles que estão ameaçados de extinção no território nacional ${ }^{95}$ e que, para estes efeitos, poderíamos considerar como zonas naturais ultra-sensiveis ${ }^{96}$.

Mas não podiam deixar de ser também relevantes as zonas "humanamente sensíveis", que são zonas de forte densidade demográfica e as paisagens importantes do ponto de vista histórico, cultural ou arqueológico.

Por fim, embora à primeira vista possa parecer surpreendente, também se consideram como sensíveis as "zonas nas quais as normas de qualidade ambiental fixadas pela legislação comunitária já foram ultrapassadas". Esta solução decorre de uma ideia de não criar "pontos negros de poluição" que fiquem para lá do ponto de não retorno. Não devem ser ultrapassados os limiares de poluição tolerável. O objectivo é evitar degradações definitivas, ou, numa palavra, irrerversibilidades. Por outro lado, outro efeito desejável desta inovadora norma, que consiste em tratar como zonas especialmente merecedoras de protecção, os locais fortemente poluídos, é promover a justiça espacial na distribuição dos riscos dos projectos e das actividades que venham a ser autorizadas. Seria normal pensar que, se já existe uma zona do território nacional onerada com actividades poluentes e incómodas, ela devesse ser escolhida para prosseguir novas actividades similares, "poupando", deste modo, zonas menos degradadas, e até simplificando a burocracia associada à aprovação e à avaliação de impacte ambiental do projecto. Mas esta solução, além de não ser boa do ponto de vista ambiental, não é equitativa na repartição dos encargos e dos riscos ambientais, pelo que deve ser evitada.

A localização de projectos, sobretudo se forem ambientalmente onerosos nos termos anteriormente descritos, em qualquer destas zonas sensíveis justifica, verificadas as restantes condições, o recurso ao princípio da precaução.

Relativamente a fenómenos naturais, o raciocínio é algo semelhante: as preocupações precaucionais são maiores nos casos em que os efeitos do fenómeno possam afectar especialmente zonas sensíveis.

\subsubsection{Impactes ambientais dos projectos}

A gravidade dos danos potenciais do projecto, actividade, ou fenómeno é maior ou menor consoante a extensão, a magnitude, a complexidade, a probabilidade, a duração, a frequência, a reversibilidade ou a natureza transfronteiriça do impacte.

\footnotetext{
${ }_{95}$ Artigo $3^{\underline{0}}$, n. $\underline{-0}_{1}$ e) da lei que cria a Rede Natura 2000 , o Decreto-lei $n .{ }^{\circ} 140 / 99$, de 24 de Abril, alterado e republicado pelo Decreto-lei n. 0 49/2005, de 24 de Fevereiro.

${ }^{96} \mathrm{~A}$ afectação de um habitat prioritário ou de uma espécie prioritária por uma acção plano ou projecto, só pode ser autorizada por motivos de protecção da saúde ou da segurança públicas, para obter consequências benéficas primordiais para o ambiente ou por outras razões imperativas de reconhecido interesse público, mediante parecer prévio da Comissão Europeia (artigo 10ํㅜ, n.ํำ da Lei da Rede Natura 2000).
} 
Vamos analisar os critérios relativos aos impactes ambientais dos projectos, um por um, a fim de vermos em que medida podem eles convocar a aplicação do princípio da precaução.

\subsubsection{Extensão}

A extensão, como decorre da própria lei, resulta da dimensão da área geográfica e da população afectada. A dimensão quantitativa dos impactes tem expressão objectiva no regime europeu de prevenção de acidentes industriais graves, onde encontramos elementos que nos auxiliam na densificação da gravidade relevante. Regulado pelo Decreto-Lei n. 0 254/2007 de 12 de Julho ${ }^{97}$, que transpõe o regime europeu de prevenção de acidentes industriais graves, considera que um acidente grave envolvendo substâncias perigosas é "um acontecimento, designadamente uma emissão, um incêndio ou uma explosão de graves proporções, resultante do desenvolvimento não controlado de processos durante o funcionamento de um estabelecimento abrangido pelo presente decreto-lei, que provoque um perigo grave, imediato ou retardado, para a saúde humana, no interior ou no exterior do estabelecimento, ou para o ambiente, que envolva uma ou mais substâncias perigosas" (artigo 2ํㅡㄹ a) $)^{98}$.

Mais concretamente, será grave, dando origem ao dever de notificação da Comissão Europeia, qualquer ocorrência que possa ter algum dos efeitos danosos descritos no anexo VII intitulado "critérios para o enquadramento de acidente grave envolvendo substâncias perigosas". Os prejuízos relevantes são pessoais, materiais, ambientais e transfronteiriços.

Atendendo aos danos pessoais, um acidente será grave sempre que provoque: um morto; seis feridos no interior do estabelecimento e hospitalizados, pelo menos, durante vinte e quatro horas; hospitalização, durante, pelo menos, vinte e quatro horas, de uma pessoa situada no exterior do estabelecimento; alojamentos localizados no exterior do estabelecimento danificados e inutilizáveis devido ao acidente; evacuação ou confinamento de pessoas durante mais de duas horas (multiplicando o $\mathrm{n} . \underline{0}$ de pessoas pelo $\mathrm{n} . .-$ de horas o valor deverá ser, pelo menos, igual a 500); interrupção dos serviços de água potável, electricidade, gás ou telefone durante mais de duas horas multiplicando o n.. de pessoas pelo $n . .-$ de horas 0 valor deverá ser, pelo menos, igual a 1000).

No que respeita aos danos materiais, consideram-se relevantes danos no estabelecimento, a partir de dois milhões de euros ou no exterior do estabelecimento a partir de meio milhão de euros.

Quanto aos danos ambientais, são graves os danos permanentes ou a longo prazo causados a 0,5 ha ou mais de um habitat terrestre importante do ponto de vista do ambiente ou de conservação da natureza, protegido por lei; 10 ha ou mais de um habitat terrestre mais amplo, incluindo terrenos agrícolas; danos significativos ou a longo prazo causados a habitats marinhos ou de água de superfície atingindo os seguintes valores: $10 \mathrm{~km}$ ou mais de um rio, canal ou ribeiro; 1 ha ou mais de um lago ou lagoa; 2 ha ou mais de um delta; 2 ha ou mais de uma zona costeira ou do mar; danos significativos causados a 1 ha ou mais de um aquífero ou a águas subterrâneas.

Por fim, são graves todos os danos transfronteiriços seja qual for a sua natureza ou dimensão.

Para evitar manipulações dolosas ou subterfúgios fraudulentos de limiares, definidos com tamanho rigor matemático, a lei construiu o conceito de "quase acidentes", que são ocorrências envolvendo as substâncias perigosas previstas no diploma que, embora não correspondam aos critérios quantitativos referidos, desencadeiam os mesmos efeitos dos acidentes, nomeadamente o dever de notificação à Comissão Europeia e a revisão dos relatórios de segurança (anexo VII, ponto II).

\footnotetext{
97 Que transpõe a Directiva 96/82, de 9 de Dezembro de 1996, alterada pelo Regulamento 1882/2003, de 29 de Setembro, e pela Directiva 2003/105 de 16 de Dezembro.

${ }_{98}^{8}$ Equivale ao artigo $3^{0}$ ก. ${ }^{\circ} 5$, da Directiva europeia.
} 


\subsubsection{Magnitude}

A magnitude, está relacionada com a intensidade do impacte (proveniente da instalação, da actividade ou do fenómeno natural) e, logicamente, com a profundidade da afectação dos valores protegidos. Não existem escalas científicas para medição da intensidade de todos os impactes mas, por exemplo, a magnitude dos impactes sonoros mede-se em decibéis, a magnitude da poluição atmosférica mede-se em nanogramas ou ppm (partes por milhão), a poluição por radioactividade mede-se em becquerels, etc. No caso de riscos associados a fenómenos naturais, existem escalas internacionalmente aceites (de Richter e Mercali para sismos, Fugita para tornados, Saffir-Simpson para furacões, etc.).

\subsubsection{Complexidade}

A complexidade do impacte depende, antes de mais, da existência de interacções prejudiciais, ou sinergias negativas, entre vários riscos. São situações em que um risco desencadeia outro, de natureza igual ou diferente, originando aquilo, a que habitualmente se chama "efeito dominó". O artigo 2ํㅡ, d) do Decreto-lei n. ${ }^{-}$254/2007, de 12 de Julho, define "efeito dominó" uma situação em que a localização e a proximidade de estabelecimentos abrangidos pelo presente decreto-lei são tais que podem aumentar a probabilidade e a possibilidade de acidentes graves envolvendo substâncias perigosas ou agravar as consequências de acidentes graves envolvendo substâncias perigosas ocorridos num desses estabelecimentos.

Em sentido mais amplo, a complexidade do impacte pode resultar também da ampliação dos riscos pela localização da fonte numa zona sensível, na acepção exposta supra, ou muito perto dela. Em casos destes, quando os efeitos típicos de um projecto, actividade, ou fenómeno afectam especialmente uma zona sensível, podemos afirmar que os impactes são agravados pela proximidade dos factores vulneráveis (humanos ou naturais) presentes nas zonas sensíveis.

É o que acontece se uma unidade industrial, onde se produzem ou armazenam substâncias químicas perigosas, estiver localizada em zona classificada para conservação da natureza, tal como uma zona húmida de importância internacional, onde se encontram espécies raras de aves selvagens migratórias, ou em zona urbana densamente povoada, onde residem milhares de pessoas.

\subsubsection{Probabilidade}

A probabilidade dos impactes pode ser avaliada quantitativa ou qualitativamente. A primeira exprime-se em números ${ }^{99}$, através de percentagens; a segunda através de critérios de razoabilidade, em função da capacidade de antevisão do “homem médio" ou do “bom pai de família”. A quantificação das probabilidades tem a vantagem de legitimar mais fortemente os órgãos decisores que devem tomar decisões juridicamente vinculativas em situações de incerteza, desresponsabilizando o decisor e delegando nos cientistas e nos peritos a responsabilidade principal do estabelecimento de nexos de causalidade.

Porém, as probabilidades não quantificadas, que se exprimem através da ideia de verosimilhança, entendida como probabilidade não quantificada de que, no futuro, possam vir a ocorrer danos ${ }^{100}$, corresponde melhor a critérios jurídicos, pelo que são preferíveis ${ }^{101}$.

\footnotetext{
${ }^{99}$ A propósito da quantificação das probabilidades, Timothy O'Riordan e James Cameron dizem que "os números dão uma aura de certeza" (Interpreting the Precautionary Principle, Earthscan, 1994, p. 62).

${ }_{100}$ Por outras palavras, Stephen Dovers ("Precautionary policy assessment for sustainability", in: Implementing the Precautionary Principle. Perspectives and Prospects, Edward Elgar, Cheltenham, 2008, p.100) diz que a precaução apela mais aos ónus legais do que aos científicos. Os ónus da prova científicos ( $95 \%$ ou $98 \%$ de certeza) são diferentes dos ónus da prova legais (ponderação de probabilidades para lá de quaisquer dúvidas razoáveis).

${ }^{101}$ A propósito da relutância judicial em atender a probabilidades matemáticas (sobretudo em processo penal) Judith S. Jones explica que uma coisa é a probabilidade dos factos e outra diferente é a provabilidade dos factos (“Certainty as Illusion: The Nature and Purpose of Uncertainty in the Law”, in: Uncertainty and Risk. Multidisciplinary Perspectives, Earthascan, London, 2008, p. 279).
} 
Assim, verosímil será um fenómeno que não seja absurdo ou irrazoável, à luz da ciência actual, mesmo que as probabilidades (quantificadas) sejam baixas.

Seguindo as palavras do juiz Boštjan M. Zupančič, do Tribunal Europeu dos Direitos do Homem, “(...) a mentalidade «civilizada», mais séria [é a] que encara a causalidade num quadro probabilístico" ${ }^{102}$. Na falta de certezas absolutas, o Direito tem que bastar-se com certezas probabilísticas, as quais não deixam de ser também certezas científicas.

A Directiva relativa à avaliação e gestão dos riscos de inundações ${ }^{103}$ é o exemplo paradigmático desta abordagem, mais probabilística do que determinística, na prevenção dos riscos. Apenas dois exemplos servem para demonstrar o probabilismo subjacente a toda a construção da Directiva Inundações:

- na avaliação preliminar do risco de inundação, os Estados devem elaborar "uma descrição das inundações ocorridas no passado que tenham tido impactos negativos importantes na saúde humana, no ambiente, no património cultural e nas actividades económicas, nos casos em que continue a existir uma probabilidade significativa de inundações semelhantes voltarem a ocorrer no futuro (...)" ${ }^{104}$

- nas cartas de zonas inundáveis que devem cobrir "as zonas geográficas susceptíveis de ser inundadas, de acordo com os seguintes cenários: a) fraca probabilidade de cheias ou cenários de fenómenos extremos; b) probabilidade média de cheias (periodicidade provável igual ou superior a 100 anos); c) probabilidade elevada de cheias, quando aplicável"105.

\subsubsection{Duração}

A importância da duração resulta de haver impactes temporários e impactes permanentes. Lógico seria que o dano durasse enquanto dura a fonte do impacte. Assim, os impactes temporários, gerariam danos temporários, e os impactes permanentes deveriam gerar danos permanentes. Mas nem sempre é assim.Na realidade, um impacte temporário, de grande intensidade e extensão, pode gerar danos permanentes. Por exemplo, a extinção de uma espécie endémica após uma mega-explosão, não seguida de incêndio nem de emissão de radiação, mas suficiente para matar todos os indivíduos da espécie, numa área considerável. Pelo contrário, os impactes permanentes podem gerar danos apenas temporários. Pensemos, por exemplo, no impacte visual de uma construção sobre uma determinada espécie de aves. Num primeiro tempo, a presença da construção afecta a espécie (efeito de "espantalho"), alterando e reduzindo a sua área de dispersão natural. Mas, após o período inicial de habituação e adaptação, as espécies retornam e retomam o padrão de dispersão anterior, como se o obstáculo não existisse, ou até utilizando-o como espaço complementar de habitat. Este fenómeno verifica-se com as cegonhas nos postes de electricidade.

\subsubsection{Frequência}

A frequência permite-nos responder à questão: quão amiúde pode ocorrer um determinado tipo de impacte num certo período de tempo? A frequência revela a repetição do impacte ao longo do tempo. Se, por um lado, a frequência é um critério de gravidade (quanto mais frequente, mais grave), por outro lado, ela permite aprender com a experiência, dissipando dúvidas e incertezas científicas.

Deste modo, a ocorrência, muito pouco frequente, de um determinado impacte, é um indicador de que podemos ter necessidade de recorrer ao princípio da precaução. Pelo contrário,

\footnotetext{
$\overline{{ }^{102} \text { Caso Baia Mare, }}$ proferido em 27 de Janeiro de 2009, no processo Tatar contra Roménia, a propósito da recusa do Tribunal quanto ao reconhecimento do nexo de causalidade entre o acidente ocorrido nas minas Aurul e os problemas de saúde sentidos pelos Srs. Vasile Gheorghe Tatar e Paul Tatar.

103 Directiva 2007/6o/CE, de 23 de Outubro de 2007.

104 Artigo $4^{\circ}$, n. ${ }^{\circ}$ 2. sublinhado nosso.

${ }^{105}$ Artigo 6으, n. $\stackrel{0}{3}$. Sublinhado nosso.
} 
um impacte com frequência elevada que já tenha ocorrido algumas vezes, torna-se altamente previsível nos seus contornos, pelo que o recurso ao princípio da precaução se considera desnecessário e ilegítimo.

\subsubsection{Reversibilidade}

A reversibilidade pode ser natural ou humana. Na realidade, alguns sistemas revelam uma capacidade de auto-regeneração espontânea e, após a cessação do impacte, os equilíbrios fisíco-químicos, biológicos e ecossistemáticos, fazem com que muitos sistemas ambientais, mesmo gravemente danificados, recuperem o equilíbrio natural inicial. Claro que, à escala humana, esse tempo pode ser longuíssimo, de milhares ou milhões de anos. Trata-se, neste caso, como já vimos, de uma irreversibilidade prática ${ }^{106}$.

Todavia, na maior parte dos casos, a reversibilidade será humanamente induzida. É a limpeza das costas após uma maré negra, é a reflorestação, é a reintrodução de espécies da fauna, é a descontaminação dos solos, é a realimentação das praias com areia dragada dos rios, etc. ${ }^{107}$. É assim que a duração dos impactes depende também de se dar início, ou não, a processos de restauração natural. Mas claro que há casos em que a requalificação ambiental, por processo de restauração natural, não é física ou biologicamente possível, e há outros em que não é economicamente exigível.

\subsubsection{Natureza transfronteiriça}

Por fim, a natureza transfronteiriça é a última característica do impacte, que resulta pura e simplesmente do reconhecimento da responsabilidade do Estado pelas actividades desenvolvidas no seu território. Independentemente da extensão, da magnitude, da complexidade, da probabilidade, da duração, da frequência ou da reversibilidade do impacte, 0 risco de afectar valores situados no território de outro Estado é um elemento de reforço da justificação do recurso ao princípio da precaução.

\subsubsection{Exemplo prático de aplicação dos critérios ao risco de inundação}

Ensaiando a aplicação dos critérios que acabámos de expor, a riscos de inundação pela cheia de um rio, verificamos que eles podem ser analisados em função da sua extensão (área geográfica e populações afectadas), magnitude (rapidez da subida e altura das águas), complexidade (uma cheia que inunda uma fábrica de produtos tóxicos e venenosos hidrossolúveis), probabilidade (plausibilidade da ocorrência), duração (tempo que as águas levam a recuar), frequência (mensal, anual, centenária), reversibilidade (se puder haver uma restauração in natura dos danos) ou natureza transfronteiriça (se pode afectar terrenos e populações dum país vizinho), ou localização (se afecta zonas sensíveis).

\subsection{Segundo pressuposto: incerteza científica}

O segundo dos pressupostos de recurso ao princípio da precaução é existência de uma incerteza científica, por isso, uma abordagem precaucional implica sempre conjecturas e “construção de cenários”"108.

${ }_{106}$ O caso da Fundição de Trail, julgado em 1937, num Tribunal Ad Hoc, marcou o início do reconhecimento desta responsabilidade dos Estados.

${ }^{107}$ Cunhal Sendim analisa com pormenor as dificuldades subjacentes à restauração natural (Responsabilidade Civil por danos ecológicos. Da reparação do dano através de restauração natural, Coimbra Editora, 1998, especialmente p. 153 e ss.).

${ }^{108}$ Joren van der Sluijs e Wim Turkenburg ("Climate Change and the precautionary principle", in: Implementing the Precautionary Principle. Perspectives and Prospects, Edward Elgar, Cheltenham, 2008 p. 277). A propósito da dificuldade de antecipar mudanças climáticas a partir da aplicação de modelos, os autores afirmam que "o passado deixou de ser uma chave fiável para o futuro" (idem, p. 262). 
Ironicamente podemos afirmar, com Gilles Martin, que a aplicação do princípio da precaução pressupõe a "prova da existência... de uma incerteza"109.

E a incerteza pode dizer respeito a três tipos de situações:

a) Aquelas em que há danos reais e confirmados, mas se desconhece a causa (dúvidas quanto ao o quê);

b) Outras, em que há uma causa hipotética para os danos reais, mas não é claro o nexo entre ambos (dúvidas quanto ao porquê);

c) e outras em que nem sequer há ainda um dano confirmado, havendo apenas suspeitas (dúvidas quanto ao se). Sobretudo neste último caso, a invocação do princípio da precaução só se justifica quando, apesar de não haver quaisquer danos comprovados (associados a um determinado produto, substância ou tecnologia), houver, mesmo assim, uma probabilidade mínima. A Comissão Europeia fala em "motivos razoáveis" mas nós preferimos falar numa verosimilhança. Verosimilhança poderia ser também a tradução, para português, da expressão inglesa "likelihood" que é "algo menos do que a probabilidade e mais do que uma remota possibilidade" ${ }^{110}$. Na ausência de danos, a verosimilhança é o limite mínimo da relevância da incerteza científica. A razão é simples: estando em causa riscos graves e irreversíveis, todas as hipóteses devem ser admitidas. No âmbito do raciocínio científico, estamos a falar do uso de simulações conceptuais ${ }^{111}$, quando é impossível desenvolver uma experiência científica para comprovar uma determinada teoria (também denominado raciocínio "what if" ${ }^{112}$ ou, numa tradução livre, raciocínio "e se"?).

Rosie Cooney distingue dois tipos de incerteza: a epistemológica, que resulta da inexistência, inadequação ou incompletude dos dados, e a ontológica, que deriva da natureza intrinsecamente complexa dos sistemas estudados, da sua escala, carácter aleatório e dinâmico, etc. ${ }^{113}$.

Mesmo a incerteza científica de tipo epistemológico, tanto se pode dever à total falta de provas científicas, como à existência de provas contraditórias.

Nas palavras de Steve Longford, "só há uma coisa pior do que não ter informação suficiente, e que é ter demasiada informação" ${ }^{14}$.

$\mathrm{Na}$ União Europeia, a controvérsia científica é intensificada quando, em virtude dos princípios da imparcialidade e do contraditório, é o próprio Conselho Europeu que promove o dever de dar especial destaque às opiniões minoritárias ${ }^{115}$.

Isto significa que, sob o impulso do princípio da precaução devemos prestar mais atenção aos "lançadores de alerta", figura muito debatida no Direito Francês, considerados por uns como os "profetas da desgraça”, ou tecno-cépticos ${ }^{116}$ que receiam sempre o "pior cenário

\footnotetext{
109 "Se não quisermos que o princípio da precaução seja invocado por tudo e por nada, em todas as petições - como acontece infelizmente na imprensa e nos discursos políticos - deve exigir-se aos requerentes que tragam perante o juiz os elementos de prova da existência... de uma incerteza” (Gilles J. Martin, "Principe de Précaution, Prévention des Risques et Responsabilité”, in: Actualité Juridique Droit Administratif, n. $\stackrel{0}{40}, 28$ Novembre 2005, p. 2223).

${ }^{110}$ Judith Jones and Simon Bronitt, "The Burden and Standard of Proof in Environmental Regulation: the Precautionary Principle in an Australian Administrative Context", in: Implementing the Precautionary Principle. Perspectives and Prospects, Edward Elgar, Cheltenham, 2008, p. 153.

${ }^{111}$ Susan Bell Trickett, e J. Gregory Trafton, “What if...”: The Use of Conceptual Simulations in Scientific Reasoning”, in: Cognitive Science Vol. 31, n. ${ }^{5}$, September-October 2007 , p. 843-875.

${ }^{112}$ Frederick Warter, “What if? Versus if it ain't broke, don't fix it”, in: Timothy O’Riordan e James Cameron, (ed.) Interpreting the Precautionary Principle, Earthscan, 1994, p. 102.

${ }_{113}$ "A Long and Winding road? Precaution from Principle to Practice in Biodiversity Conservation", in: Implementing the Precautionary Principle. Perspectives and Prospects, Edward Elgar, Cheltenham, 2008 p. 229.

${ }_{114}$ "Uncertainty in Decision-making: inteligence as solution”, in: Uncertainty and Risk. Multidisciplinary Perspectives, Earthascan, London, 2008, p. 219.

${ }^{115}$ Orientação que resulta do ponto 10 da Resolução do Conselho Europeu de Nice, em 9 de Dezembro de 2000.

${ }^{116}$ Indivíduos que, nas palavras de Silvio Funtowicz, padecem do “sindroma Challenger-Chernobyl” (Silvio O. Funtowicz e Jerome R. Ravetz, "Three types of Risk Assessment and the Emergence of Post-Normal Science", in: Social Theories of Risk, Sheldon Krimsky e Dominic Golding (Ed) Praeger, London, 1992, p. 267 e também“Scienza e decisioni di polity", in: Notizi di Politeia, anno XIX, n.ํㅜㄱ, 2003, p.29 a 30).
}

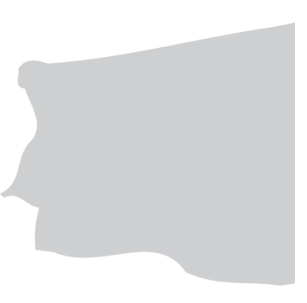


possível" ${ }^{117}$ mas a cujas opiniões, desde que minimamente verosímeis e motivadas por razões altruístas (e não de concorrência comercial, de visibilidade mediática, de vingança, ou outras) não podemos simplesmente fechar os olhos.

Ora, se a incerteza científica tanto pode residir na causa, como no efeito, como no nexo, interessa agora saber por que é que, num tempo em que a ciência impera, ainda subsistem tantas incertezas científicas. E as razões podem ser várias:

- primeiro, podemos estar perante substâncias ou tecnologias muito recentes e inovadoras, cujos impactes ambientais ainda são pouco conhecidos (por exemplo, as nanotecnologias ou os organismos geneticamente modificados) mas que podem afectar as próximas gerações (maxime, através de efeitos mutagénicos).

- depois, pode também acontecer que os impactes tenham sido estudados apenas em contexto laboratorial, e não em contexto ambiental real; apenas numa escala temporal de anos ou décadas quando devia ter sido de séculos ou milénios; e apenas numa escala espacial restrita e não numa escala alargada a todo o "mercado planetário" (por exemplo, a infinidade de substâncias químicas utilizadas comercialmente como aditivos alimentares ou noutras funções, cuja descoberta, produção e comercialização é recente ${ }^{118}$ e cujos testes prévios foram relativamente limitados).

- por fim, pode ainda acontecer que os efeitos ambientais de uma tecnologia tradicional não fossem evidentes e só recentemente começassem a ser notados em virtude do tempo decorrido desde a sua primeira aplicação ou da explosão geográfica e da intensidade da utilização (caso das alterações climáticas por GEE, da destruição da camada de ozono pelos CFC, ou das radiações electromagnéticas provenientes de antenas retransmissoras de telemóvel ou de linhas eléctricas de alta tensão). Estes são exemplos de tecnologias "tradicionais" e que até à data não tinham dado razões para recear impactes ambientais ou humanos ${ }^{119}$.

Andy Stirling, Ortwin Renn e Patrick van Zwanenberg ${ }^{120}$, apresentam uma ilustração esquemática que mostra quatro graus de dúvida que designam sucessivamente por risco, incerteza, ambiguidade e ignorância:

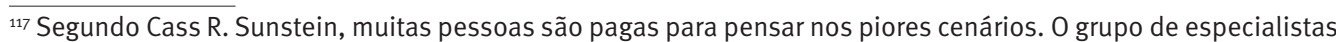
em piores cenários é grande: inclui médicos, juristas, líderes militares, secretários de estado da defesa, ambientalistas e todas as pessoas que trabalham em companhias de seguros. (Worst Case Scenarios, Harvard University Press, Cambridge, 2007, p. 275).

${ }^{118}$ Estamos a pensar na proliferação de aditivos alimentares (como antioxidantes reguladores de acidez, anti-aglomerantes, aromatizantes, agentes de volume, corantes, emulsionantes, intensificadores de sabor, humidificantes, conservantes, espessantes, gelificantes, edulcorantes, endurecedores; levedantes; agentes de brilho) mas, sobretudo, nos aditivos não alimentares que, por não se destinarem a ser ingeridos, beneficiam de um regime menos rígido (como estabilizantes, plastificantes, lubrificantes, agentes antiestáticos, retardantes de chama, pigmentos e corantes, agentes de expansão, agentes anti-embaciamento, espumantes, anti espumantes, etc.).

${ }_{119}$ Uma boa ilustração da persistência da incerteza científica e da conflituosidade que se gera em torno dela é o processo T-334/07, decidido pelo Tribunal de Primeira Instância em 19 de Novembro de 2009. Neste recurso de anulação, a empresa Denka International de produtos fitofarmacêuticos pretende que seja declarada a invalidade de uma decisão da Comissão que não autoriza a utilização comercial de uma substância biocida (diclorvos) eficaz na protecção dos bolbos das flores, em estufas. A decisão contestada baseou-se na não demonstração, pelos requerentes, de que os riscos de efeitos genotóxicos e cancerinogénicos da substância fossem aceitáveis. A incerteza quanto aos efeitos da substância activa na saúde humana e no ambiente resulta do tipo de riscos, cuja verificação exige monitorização dos efeitos (maxime, os efeitos mutagénicos) da exposição, ao longo de várias gerações; do resultado dos testes (os ratos desenvolveram cancro precisamente numa zona do estômago que não tem equivalente no Homem) e, em geral, da qualidade medíocre dos dados científicos apresentados pelo requerente.

120 "A Framework for the precautionary governance of food safety: integrating science and participation in the social appraisal of risk", in: Implementing the Precautionary Principle. Perspectives and Prospects, Edward Elgar, Cheltenham, 2008 p. 288.
} 


Conhecimento
da probabilidade

Conhecimento das possibilidades (resultados) Problemático

\author{
AMBIGUIDADE \\ Ex. Cenários de efeito de estufa \\ Impactes energéticos \\ Danos por OGMs
}

IGNORÂNCIA

Ex. Encefalopatias Espongiformes(BSE)

CFC e o buraco do ozono

Perturbadores endócrinos

O risco, (no canto superior esquerdo) corresponde à situação em que existe, cientificamente, a capacidade de caracterizar as diferentes possibilidades e determinar com confiança a sua probabilidade relativa.

0 estado de incerteza (no canto inferior esquerdo), é uma condição em que os resultados possíveis são claros (os graus de danos ou de benefício) mas as probabilidades são difíceis de quantificar.

A ambiguidade (canto superior direito) surge quando o problema não são as probabilidades mas a identificação dos próprios cenários que resultam do produto ou actividade potencialmente danosa.

Finalmente, a ignorância (canto inferior direito) ocorre quando nem as probabilidades nem os resultados podem ser caracterizados plenamente ou com segurança. Neste último caso, segundo os autores, "nem sabemos o que não sabemos"

Para Silvio Funtowicz a incerteza pode ser "temporária”, se for teoricamente eliminável, desde que haja tempo e recursos, ou "irredutível" ${ }^{122}$, na medida em que esteja ínsita na natureza da própria metodologia científica ${ }^{123}$.

Perante tanta incerteza, a conclusão à qual se chega é que as ciências "duras" estão cada vez mais "moles" (na medida em que não conseguem prever os efeitos das novas tecnologias e se limitam a apresentar hipóteses e probabilidades) e apesar disso - ou por causa disso - , pede-se às ciências "moles" (como as ciências sociais e o Direito, que tomem decisões "duras") ${ }^{124}$. Quando, sem uma base científica sólida, se exigem ao Direito decisões juridicamente vinculativas em condições de grande incerteza, ou seja, decisões de sim ou não sobre actividades, produtos, substâncias ou técnicas, os juristas devem agir com prudência e um especial bom-senso na aplicação das medidas evitatórias.

Assim, os juristas vão desenvolvendo formas de controlar o futuro, como o recurso cada vez mais frequente a dados estatísticos, com a imposição de planeamento plurianual obrigatório num número crescente de sectores ${ }^{125}$, ou com a avaliação ambiental das grandes

\footnotetext{
${ }^{121}$ Ibidem, p. 289.

122 "Scienza e decisioni di polity", in: Notizi di Politeia, anno XIX, n.ํำ70, 2003, p.34.

${ }^{123}$ Usando uma sugestiva metáfora, este autor procura caracterizar a ignorância: "é impossível definirmos a ignorância mas o mar ilimitado da ignorância banha costas das quais é possível traçar um mapa”. "Scienza e decisioni di polity", in: Notizi di Politeia, anno XIX, n. $\stackrel{0}{7} 70,2003$, p. 25 .

${ }^{124}$ Por exemplo, a decisão de encerrar uma instalação industrial ou de retirar um produto do mercado, quando ainda não há provas irrefutáveis da sua nocividade. A ideia das ciências “moles" a proferir decisões “duras" é também de Silvio Funtowicz, na mesma obra, (p. 24).

${ }^{125}$ Os planos são precisamente documentos de prospectiva que pretendem antever e apreender antecipadamente as questões que se vão colocar no futuro. Integrando ambiente e saúde, o Plano Nacional Ambiente e Saúde é um óptimo exemplo de um documento estratégico que reflecte uma abordagem precaucional relativamente aos danos na saúde, causados pela degradação do ambiente ou pela proximidade ou contacto com elementos ambientais
} 
decisões estratégicas de desenvolvimento ${ }^{126}$. Sabendo que o risco zero ${ }^{127}$ é "uma ficção" ${ }^{128} \mathrm{e}$ que não se pode exigir a prova da inocuidade total das actividades e produtos autorizados, estas são algumas das armas dos juristas para combater a incerteza.

Mas a melhor forma de garantir a prudência e o bom-senso, perante a necessidade inadiável de tomar decisões concretas, é o respeito do princípio da proporcionalidade ${ }^{129}$.

Nesse caso, como veremos no capítulo 5.3.3., a defesa dos juristas passa por tomar decisões de gravidade proporcional ao risco e à inaceitabilidade social do risco, decisões que devem ser sempre provisórias, revisíveis e revistas periodicamente, através de procedimentos flexíveis, participados e iterativos.

perigosos (químicos, radioactivos, etc.) ou até epidemias sem agente patogénico, como acontece com as mortes por ondas de calor. Outros exemplos são os vários planos de gestão de resíduos (o plano nacional de gestão de resíduos, os planos específicos de gestão de resíduos e os planos multimunicipais, intermunicipais e municipais de acção previstos actualmente nos artigos $13^{\circ}$ a $18^{\circ}$ da Lei dos Resíduos, O Decreto-lei n. $\stackrel{0}{178 / 2006}$ de 5 de Setembro) planos hidrográficos, (o plano nacional da água, os planos de ordenamento de albufeiras de águas públicas, os planos de ordenamento da orla costeira, os planos de ordenamento dos estuários, os planos de gestão de bacia hidrográfica, os planos específicos de gestão de águas [abrangendo uma sub-bacia ou uma área geográfica específica, ou então abrangendo um problema, tipo de água, aspecto específico ou sector de actividade económica com interacção significativa com as águas]), os planos do turismo (por exemplo, o Plano Estratégico

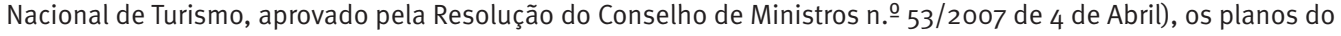
ordenamento do território (como o Programa Nacional da Política de Ordenamento do Território, aprovado pela Lei n. ${ }^{\circ}$ 58/2007, de 4 de Setembro).

Segundo Jean-Marie Pontier os planos de riscos servem para sensibilizar a população, para regulamentar a ocupação do território, para instituir obrigações de fazer ou não fazer. («Le droit de la prévention des risques, droit en devenir des sociétés développées, d'aujourd'hui et de demain», in Les plans de prévention des risques, Université Paul Cézanne- Aix Marseille III, 2007, p. 70).

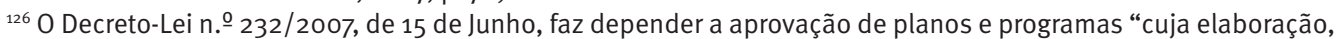
alteração ou revisão por autoridades nacionais, regionais ou locais ou outras entidades que exerçam poderes públicos, ou aprovação em procedimento legislativo, resulte de exigência legal, regulamentar ou administrativa”, de uma avaliação ambiental estratégica.

${ }^{127} \mathrm{O}$ risco zero é uma situação ideal e utópica que, na lei sobre a segurança geral dos produtos (Decreto-Lei n.o 69/2005 de 17 de Março) parece, à primeira vista, ter sido adoptada. Com efeito, sendo o objectivo daquela lei, garantir a segurança dos produtos e serviços colocados no mercado, e preocupando-se a lei em esclarecer o que é um "produto seguro", parecia realmente transmitir a ideia de ser possível eliminar completamente os riscos inerentes aos produtos colocados no mercado. Um “produto seguro” é "qualquer bem que, em condições de utilização normais ou razoavelmente previsíveis, incluindo a duração, se aplicável a instalação ou entrada em serviço e a necessidade de conservação, não apresente quaisquer riscos ou apresente apenas riscos reduzidos compatíveis com a sua utilização e considerados conciliáveis com um elevado nível de protecção da saúde e segurança dos consumidores (...)" (artigo 3ํㅡ) b).

Porém, uma análise mais cuidada revela que se trata apenas de um abuso de linguagem, pois se a primeira situação contemplada é perfeitamente utópica (um produto seguro é aquele que não apresenta "quaisquer riscos“) já a segunda é mais razoável e compatível com o princípio da precaução: um produto seguro é aquele que apresenta “riscos reduzidos". Foi mesmo o princípio da precaução que motivou, em 2001, a alteração da Directiva 92/59, de 29 de Junho, pela Directiva 2001/95, de 3 de Dezembro. Esta Directiva devia ter sido transposta até Janeiro de 2004 mas em Portugal foi transposta apenas em Março de 2005. Curiosamente, esta lei considera, e bem, a vulnerabilidade social como factor agravante do risco. Assim, na determinação da segurança do produto atender-se-á às “características do produto, designadamente a sua composição”, à “apresentação, a embalagem, a rotulagem e as instruções de montagem, de utilização, de conservação e de eliminação, bem como eventuais advertências ou outra indicação de informação relativa ao produto", aos “efeitos sobre outros produtos quando seja previsível a sua utilização conjunta e às "categorias de consumidores que se encontrarem em condições de maior risco ao utilizar o produto, especialmente crianças e os idosos” (artigo $3^{\circ}$ b), I, II, III, e IV).

${ }^{128}$ Jean-Marc Favret, «Le principe de précaution ou la prise en compte par le droit de l’incertitude scientifique et du risque virtuel», in: Dalloz, 6 Décembre, 2001, p. p. 3463.

${ }^{129}$ A propósito da importância do princípio da proporcionalidade na aplicação do princípio da precaução, Sadeleer usa a imagem de que "de nada serve matar moscas com um martelo pneumático" (Nicolas de Sadeleer, "Les Avatars du Principe de Précaution en Droit Public. Effet de Mode au Révolution Silencieuse?» in: Revue Française de Droit Administratif, 2001, Mai-Juin, p.559). 


\section{0 processo de aplicação do princípio da precaução}

Depois de determinada a necessidade de recorrer ao princípio da precaução, na sua aplicação ao caso concreto, há questões de governância dos riscos que devem ser resolvidas ${ }^{130}$. $\mathrm{Na}$ Europa, a governância estrutura-se em torno de um conjunto de princípios ${ }^{131}$, a saber: transparência ${ }^{132}$, abertura, participação, responsabilização, eficácia e coerência.

Para melhor compreender como a governância se relaciona com o princípio da precaução, e em que medida é que os princípios da governância influenciam o processo de aplicação do princípio da precaução, vamos considerar três momentos de ponderação relevantes, no processo de aplicação do princípio da precaução:

1. a ponderação de vantagens e inconvenientes da acção pretendida;

2. a avaliação da aceitabilidade social dos riscos;

3. a escolha das medidas precaucionais, adequadas e proporcionais

Em cada um dos momentos, os princípios da governância influenciam de forma determinante, objectivando a avaliação e racionalizando as escolhas.

O princípio da eficácia ${ }^{133}$, releva sobretudo na ponderação das vantagens e inconvenientes e na escolha das medidas precaucionais.

Os princípios da participação ${ }^{134} \mathrm{e} \mathrm{da}$ abertura ${ }^{135}$ são especialmente importantes na percepção da aceitabilidade social dos riscos.

O princípio da coerência ${ }^{136}$, é crucial na escolha das medidas precaucionais.

Em todos os momentos, o princípio da transparência impõe-se como uma exigência muito especial na regulação de decisões polémicas como são forçosamente as que convocam o princípio da precaução.

\footnotetext{
130 “A par das questões de avaliação, gestão e comunicação de riscos, a governância dos riscos estende-se a questões de configuração institucional, processo legislativo, estilo de consultas, cultura organizacional, acreditação de peritos, escolha de metodologias, accountability política, negociação com stakeholders [grupos de interesses] resolução de conflitos e exercício de poder". (Andy Stirling, Ortwin Renn e Patrick van Zwanenberg, "A Framework for the precautionary governance of food safety: integrating science and participation in the social appraisal of risk", in: Implementing the Precautionary Principle. Perspectives and Prospects, Edward Elgar, Cheltenham, 2008 p. 286). ${ }^{131}$ Presentes no Livro Branco da Governança Europeia, COM(2001) 428 final, Bruxelas, 25 de Julho de 2001, p. 11. Sobre a opção linguística entre "governança" e "governância", ver o nosso artigo sobre «A Governância na Constituição Europeia. Uma oportunidade perdida?», in: A Constituição Europeia. Estudos em homenagem ao Prof. Doutor Lucas Pires, FDUC, Coimbra, 2005.

${ }^{132}$ Apesar de o princípio da transparência não ter consagração autónoma, ele está inegavelmente presente ao longo de todo o Livro Branco, sendo a ideia de transparência mencionada cinco vezes, a vários propósitos, a começar pela apresentação do princípio da abertura.

133 “As políticas deverão ser eficazes e oportunas, dando resposta às necessidades com base em objectivos claros, na avaliação do seu impacto futuro e, quando possível, na experiência anterior. A eficácia implica também que as políticas da União Europeia sejam aplicadas de forma proporcionada aos objectivos prosseguidos e que as decisões sejam adoptadas ao nível mais adequado" (Livro Branco... p.11).

${ }_{134}$ "A qualidade, pertinência e eficácia das políticas da União Europeia dependem de uma ampla participação através de toda a cadeia política - desde a concepção até à execução. O reforço da participação criará seguramente uma maior confiança no resultado final e nas instituições que produzem as políticas. A participação depende principalmente da utilização, por parte das administrações centrais, de uma abordagem aberta e abrangente, no quadro do desenvolvimento e aplicação das políticas da União Europeia” (loc. cit.).

135 "As instituições deverão trabalhar de uma forma mais transparente. Em conjunto com os Estados-Membros, deverão seguir uma estratégia de comunicação activa sobre as tarefas da União e as suas decisões. Deverão utilizar uma linguagem acessível ao grande público e facilmente compreensível. Este aspecto reveste particular importância para melhorar a confiança em instituições complexas" (loc. cit.).

136 “As políticas e as medidas deverão ser coerentes e perfeitamente compreensíveis. A necessidade de coerência na União é cada vez maior: o leque das tarefas aumentou; o alargamento virá aumentar a diversidade; desafios como a mudança climática e a evolução demográfica extravasam as fronteiras das políticas sectoriais, em que a União se tem vindo a basear; as autoridades regionais e locais estão cada vez mais envolvidas nas políticas da União Europeia. A coerência implica uma liderança política e uma forte responsabilidade por parte das instituições, para garantir uma abordagem comum e coerente no âmbito de um sistema complexo" (loc. cit.).
} 


\subsection{Primeiro momento: ponderação de vantagens e inconvenientes}

Muitos discursos empolgados, a favor ou contra o princípio da precaução, baseiam-se no preconceito de que a decisão que se tomar será a favor de um produto ou uma tecnologia boa, e contra um produto ou uma tecnologia má, ou vice-versa... Mas as decisões que convocam o princípio da precaução são mais complexas e menos maniqueístas do que a forma como os detractores do princípio as apresentam.

Felizmente para o mundo (mas infelizmente para quem tem o dever de decidir), quase sempre o produto, a tecnologia ou a actividade, que envolvem riscos importantes, também comportam enormes vantagens económicas, sociais e até ambientais, colocando, frequentemente, os decisores públicos perante um dilema paralisante. Um bom exemplo são os projectos ligados a algumas fontes de energia renovável, como a construção de barragens para produção de energia hidroeléctrica, ou a plantação de cana-de-açúcar para produção de biocombustíveis. 0 objectivo de produzir energia limpa e lutar contra o efeito de estufa é, incontestavelmente, um objectivo importante e nobre. Mas a aura de bondade ambiental de que beneficiam estes projectos não deve fazer-nos esquecer que eles também podem ter impactes ambientais ou sócio-económicos significativos.

No caso das barragen $\mathrm{s}^{137}$, investimentos avultadíssimos, com um tempo de vida relativamente limitado e riscos elevados, relevam as alterações dos fluxos hidrológicos, a perturbação dos ecossistemas, tanto terrestres como fluviais, e a criação de micro-climas locais, que podem ser prejudiciais a certas actividades económicas, como a viticultura.

No caso dos biocombustíveis, um dos aspectos mais criticáveis é a afectação dos solos agrícolas (cada vez mais escassos num mundo com uma população de quase sete mil milhões de habitantes, com fenómenos de urbanização e desertificação crescentes), à produção de variedades vegetais não alimentares, concorrendo assim com a agricultura ${ }^{138}$ para produção de alimentos.

0 principal problema reside no facto de, muitas vezes, as vantagens estarem concentradas num local geográfico determinado e num momento temporal, que é a actualidade, enquanto os inconvenientes são geograficamente difusos e reportam-se a um momento futuro.

Curiosamente, a inversa também pode ser verdadeira: se pensarmos concretamente nas acções de proteç̧ão ambiental activa (medidas como a reflorestação, a reintrodução de espécies selvagens, a descontaminação de solos, a requalificação fluvial ou a própria luta contra as alterações climáticas) apercebemo-nos de que envolvem custos actuais e benefícios futuros.

Outro exemplo é a energia nuclear de fissão, que propicia a enorme vantagem para as gerações actuais de uma disponibilidade energética quase ilimitada à disposição da economia actual, mas comporta também enormes inconvenientes, que são os eternos resíduos radioactivos e o risco de acidentes no futuro.

Uma das razões, pelas quais preferimos falar de vantagens e inconvenientes, e não de custos e benefícios, é pretendermos afastar ponderações puramente economicistas baseados em cálculos que, em matéria ambiental, são difíceis de realizar. Isto não significa que não se possam fazer análises de custo-benefício; significa apenas que elas podem conduzir a conclusões perniciosas.

\footnotetext{
${ }^{137}$ Vejam-se os impactes de uma mega-barragem na descrição do Empreendimento de Fins Múltiplos de Alqueva, disponivel em http://www.edia.pt.

${ }^{138}$ Este problema é amplamente debatido por Lester Brown em Plan B 2.0, Rescuing a Planet Under stress and a Civilization in Trouble, Earth Policy Institute, W.W. Norton \& Company, New York, 2006.
} 
A contabilização, estritamente económica ${ }^{139}$, de ganhos e perdas, não deve aplicar-se aos riscos ambientais, por duas razões. Primeiro, porque, como já dissemos, além das vantagens e desvantagens sentidas "aqui-e-hoje", se pretende igualmente abarcar as vantagens ou desvantagens que venham a ocorrer "além-e-amanhã". E, se nem sempre é fácil contabilizar economicamente efeitos actuais e locais, muito mais difícil é contabilizar impactes futuros e remotos. Segundo, porque sendo o princípio da precaução uma ferramenta importante na prossecução do desenvolvimento sustentável, além do aspecto económico, pretende-se abranger também os aspectos sociais e ambientais das decisões. E o que é certo é que o bem-estar, a qualidade de vida, a biodiversidade e o equilíbrio dos ecossistemas, que são valores fundamentais, são também muito dificilmente redutíveis a dinheiro.

\subsubsection{Instrumentos de ponderação}

Já dissemos que, de acordo com as regras de governância, a ponderação de vantagens e inconvenientes deve resultar de um processo pluridisciplinar, contraditório, independente e transparente. Já existem, consagrados na lei, alguns instrumentos de avaliação ambiental abrangente, de carácter simultaneamente jurídico e científico ${ }^{140}$, que reúnem estas características.

Referimo-nos, antes de mais, ao procedimento de avaliação de impacte ambiental de projectos, aplicável aos projectos listados na Lei de Avaliação de Impacte Ambiental (AIA) e na Directiva relativa à Avaliação de Impacte Ambiental ${ }^{141}$. Como exemplos de critérios de ponderação, temos os já referidos anteriormente - dimensão da população afectada, probabilidade de ocorrência do dano, reversibilidade do dano, extensão geográfica, a importância dos valores pessoais e naturais afectados, etc.

Diferentemente da AIA europeia, em Portugal, cabe à autoridade de AIA ponderar não só os impactes ambientais mas também sociais, do projecto. Artigo $2^{\circ}$, j) «lmpacte ambiental»"conjunto das alterações favoráveis e desfavoráveis produzidas em parâmetros ambientais e sociais, num determinado período de tempo e numa determinada área, resultantes da realização de um projecto, comparadas com a situação que ocorreria, nesse período de tempo e nessa área, se esse projecto não viesse a ter lugar". Num sistema em que a decisão final de AIA é vinculativa, o objectivo da lei foi garantir que a ponderação das dimensões ambientais e sociais do projecto são conjuntamente ponderadas pela autoridade de AIA sem que argumentos de natureza social possam servir para justificar posteriormente projectos com impactes ambientais comprovados.

A reconhecida insuficiência ambiental da avaliação dos impactes de projectos, levou à criação do regime de avaliação de impacte ambiental de planos e programas, ou avaliação estratégica, aprovada em Portugal, em 15 de Junho de 2007, pelo Decreto-lei n- 232/2007, (que transpõe, para o ordenamento jurídico português, a Directiva 2001/42, de 27 de Junho). A avaliação estratégica consiste na "identificação, descrição e avaliação dos eventuais efeitos significativos no ambiente resultantes de um plano ou programa, realizada durante um procedimento de preparação e elaboração do plano ou programa e antes de o mesmo ser aprovado ou submetido a procedimento legislativo, concretizada na elaboração de um

\footnotetext{
139 David Pearce reconhece que a adopção do princípio da precaução pode ser dispendiosa, mas seja qual for a regra de abstenção ou de acção que se aplique, ela vai sempre implicar um valor económico (The Precautionary Principle and Economic Analysis", in: Timothy O’Riordan e James Cameron, (ed.) Interpreting the Precautionary Principle, Earthscan, 1994, p. 145).

${ }^{140}$ Segundo Gomes Canotilho, o Estado Constitucional Ecológico assume o “dever de acompanhar todo o processo produtivo e de funcionamento sob um ponto de vista ambiental” ("Estado Constitucional Ecológico e Democracia Sustentada", in: RevCEDOUA, nㅇ 8, ano IV, 2, 2001, p. 12).

${ }_{141}$ Decreto-Lei n. 0 69/2000, de 3 de Maio, (com as alterações do Decreto-Lei n. 0 74/2001, de 26 de Fevereiro, do

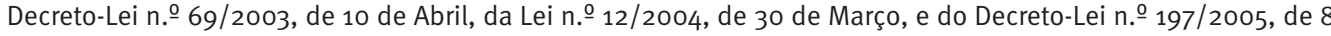
de Novembro). A Directiva é a n. 85/337, de 27 de Junho de 1985, alterada em 1997, pela Directiva 97/11, de 3 de Março, e pela Directiva 2003/35, de 26 de Maio.
} 
relatório ambiental e na realização de consultas, e a ponderação dos resultados obtidos na decisão final sobre o plano ou programa e a divulgação pública de informação respeitante à decisão final". (artigo $2^{0}$ a). Assentando numa estrutura substancialmente idêntica à da AIA, este procedimento promove uma ponderação dos impactes ambientais das grandes opções estratégicas, reforçando a abordagem preventiva e permitindo uma maior eficácia das medidas pró-ambientais.

Por fim, a ponderação das vantagens e inconvenientes deve passar também pela análise dos impactes regulatórios ${ }^{142}$, que, na União Europeia foi introduzido em 2002, tendo sido actualizado em 2009, com a adopção das Linhas Orientadoras da Comissão Europeia Relativas à Avaliação de Impactes ${ }^{143}$, segundo a qual a avaliação de impactes é um "conjunto de etapas lógicas a seguir aquando da preparação de propostas legislativas" (p. 5), um processo que conduz à recolha de informações sobre as vantagens e os inconvenientes das opções políticas possíveis, através de um exame dos seus impactes potenciais. A OCDE tem igualmente dedicado grande atenção nos últimos anos ${ }^{144}$ à análise dos impactes regulatórios.

Estes impactes são analisados em três categorias: as incidências económicas, as sociais e as ambientais.

Quanto às incidências económicas, são objecto de análise questões como o funcionamento do mercado interior e as relações internacionais, a concorrência, os encargos administrativos suportados pelas empresas e a competitividade, a inovação e investigação, os consumidores e economias domésticas, e o ambiente macro-económico.

Os impactes sociais, na União Europeia, são avaliados de acordo com as linhas orientadoras adoptadas em $2009^{145}$ e cobrem os impactes sobre o emprego e o mercado de trabalho, não discriminação, inclusão social e protecção de grupos particulares, equidade no tratamento e igualdade de oportunidades, protecção social, segurança social, saúde pública, etc..

Relativamente às incidências ambientais, elas cobrem sobretudo o clima, transporte e consumo de energia, qualidade do ar, biodiversidade, flora, fauna e paisagem, qualidade da água, qualidade dos solos e recursos geológicos, recursos renováveis, produção e reciclagem de resíduos, amplitude dos riscos ambientais e bem estar dos animais, entre outros.

\subsubsection{O resultado da ponderação: justiça intrageracional e intergeracional}

Dissemos que o princípio da precaução era um princípio de justiça. A justiça inerente ao princípio da precaução resulta do reconhecimento de um facto: os riscos não afectam igualmente as populações nem os territórios. Primeiro, porque são as pessoas e as comunidades mais vulneráveis que mais sofrem com os riscos; segundo, porque os riscos (ao contrário das vantagens) se fazem sentir, essencialmente, no futuro. 0 princípio da precaução é, por isso, uma via para a realização da justiça, tanto numa perspectiva espacial como temporal, ou, por outras palavras, é um princípio de justiça inter e intrageracional.

Comecemos pela dimensão mais óbvia do princípio da precaução, a dimensão diacrónica, enquanto princípio de realização da justiça intergeracional.

De facto, os efeitos da inércia, na adopção de medidas precaucionais, fazem-se sentir sempre no porvir. Não podemos esquecer que muitos dos riscos, que convocam a aplicação do princípio da precaução, são riscos aos quais chamámos retardados, cujos danos se manifestam através de um padrão de crescimento exponencial. Pode ser um futuro mais

\footnotetext{
${ }_{142}$ Ragnar E. Löfstedt, “The Swing of the Regulatory Pendulum in Europe: From Precautionary Principle to (Regulatory) impact analysis", in: The Journal of Risk and Uncertainty, 28:3, 2004, p. 237-260.

${ }^{143}$ SEC(2009) 92, 15 de Janeiro de 2009.

144 Sobretudo desde o relatório de 1997 Regulatory Impact Analysis: Best Practice in OECD Countries, (OECD, Paris), até à adopção dos OECD Guiding Principles for Regulatory Quality and Performance, (OECD, Paris, 2005)

${ }_{145}$ Guidance for assessing Social Impacts within the Commission Impact Assessment System, Ref. Ares(2009)326974 $-17 / 11 / 2009$.
} 
ou menos longínquo, mas será, em regra, um momento bastante posterior ao momento da tomada de decisão. Expressão acabada da nova responsabilidade pelo futuro $0^{146}$, o princípio da precaução protege sobretudo as gerações futuras, impotentes perante as consequências das decisões e das acções das gerações actuais. Estes são os contornos principais da importantíssima dimensão temporal do princípio da precaução.

Já numa perspectiva sincrónica, ou de justiça intrageracional, o princípio da precaução é uma ferramenta fundamental em virtude da injustiça da incidência social e territorial dos riscos, no sentido de que o dano excepcional, que resulta de uma catástrofe, causa uma ruptura na igualdade dos cidadãos ${ }^{147}$.

E é um facto que são as populações social, económica e geograficamente mais vulneráveis as mais afectadas, tanto em termos absolutos como em termos relativos, pelos riscos. Por isso, um aspecto importante da ponderação de vantagens e inconvenientes é a consideração da vulnerabilidade das comunidades humanas afectadas. A vulnerabilidade é uma forma de fragilidade social, económica, cultural e geográfica ${ }^{148}$, que expõe mais gravemente aos riscos certos indivíduos e certas comunidades ${ }^{149}$.

\subsubsection{Riscos territoriais, vulnerabilidade geográfica}

Se pensarmos menos em termos de probabilidade temporal, e mais em probabilidade espacial, verificamos que há uma infeliz coincidência entre a ocorrência geográfica dos riscos e a ocupação do solo por populações vulneráveis ${ }^{150}$, a qual dá origem à injustiça na repartição espacial dos riscos, à qual aludíamos antes.

As vítimas mais frequentes dos riscos são quem vive paredes-meias com a desgraça, residindo em locais muitas vezes não urbanizáveis ${ }^{151}$, mais expostos aos riscos territoriais, sejam naturais (como inundações, avalanches, deslizamentos de terras) sejam tecnológicos ${ }^{152}$ (acidentes industriais químicos, radiológicos, incêndios, explosões, etc.).

Daí a utilidade das cartas de riscos, anexas aos planos de ordenamento territorial ${ }^{153}$, que são representações geográficas dos riscos, servem para todos os domínios do risco, natural ou antrópico, e revelam a distribuição espacial dos riscos: as zonas ameaçadas, as características dos danos e os efeitos da concretização do risco, os valores vulneráveis, etc..

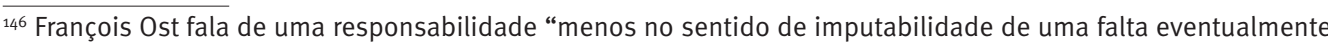
cometida num dado momento do passado, do que no sentido de uma missão assumida para o futuro" ("Ecología y Derechos del Hombre", Humana lura, n. $.6,1996$, p.208).

${ }_{147}$ Marie-Béatrix Crescenzo-d'Auriac, Les Risques Catastrophiques, Évènements Naturels, Politiques et Technologiques, L’Argus, Paris, 1988, p.13 e ss.

${ }^{148}$ Margatet R. Somers, trata da coincidência dos riscos com a vulnerabilidade social Genealogies of citizenship. Markets, statelessness and the right to have rights, Cambridge University Press, 2008.

149 Esta é a situação em que estão a República do Vanuatu e o Reino do Tuvalu, ambos Estados do Pacífico Sul, cujo território corre o risco de desaparecer sob as águas oceânicas, em virtude da subida do nível médio do mar. As migrações forçadas de refugiados climáticos, para fora do seu país, sem previsão de retorno, são um problema complexo, e infelizmente já actual, com relevância internacional crescente, com o qual estão confrontados os respectivos governos, e que envolvem negociações com os grandes Estados vizinhos: Austrália e Nova Zelândia.

${ }^{150} \mathrm{Em}$ França, 70\% dos estabelecimentos industriais mais perigosos estão implantados em áreas urbanas. Éliane Propeck, Theirry Saint-Gérand, “Espace et risques”, in: Dictionaire des Risques, Yves Dupont (dir), Armand Colin, Paris, 2007, p. 206.

${ }^{151}$ Sobre riscos urbanísticos ver Alves Correia, "Risco e Direito do Urbanismo", in: Revista de legislação e Jurisprudência, n.으 3955, Março-Abril 2009.

${ }^{152}$ Benjamin Davy estuda essencialmente o fenómeno da exclusão social através dos LULUS - Localy Unwanted Land Uses ou Usos Indesejáveis do Solo ao Nível Local na obra Essential injustice: when legal institutions cannot solve environmental and land use disputes, Springer-Verlag, Wien, New York, 1997.

${ }^{153}$ Orientações Gerais do Secretario de Estado do Ordenamento do Território e das Cidades para a Elaboração dos Planos Regionais de Ordenamento do Território, de Novembro de 2005, p. 18.
}

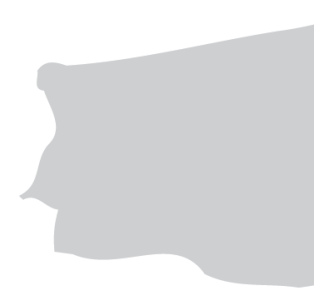

(D) 


\subsubsection{Riscos difusos, outras vulnerabilidades}

Em relação aos riscos difusos, é um facto que as populações sem recursos materiais, populações social, cultural e economicamente carenciadas, são as vítimas mais frequentes e mais graves dos riscos 154

Em relação aos riscos difusos ou não territoriais, estas são também as principais vítimas cidadãos sem-abrigo que sofrem mais pela dificuldade de tomar medidas de auto-protecção, por não possuírem, por exemplo, meios adequados de aquecimento ou refrigeração, que os protegeriam das ondas de frio ou de calor.

Em suma, além da convivência forçada com os riscos, as populações desfavorecidas são ainda as vítimas mais graves dos riscos, na medida em que vivem em condições mais difíceis (ocupando habitações precárias e degradadas), não têm conhecimentos nem condições para prevenir a ocorrência dos danos (baixa escolaridade e dificuldades ao nível da leitura, sem computador ou telemóvel para receber informação em tempo real sobre a proximidade do risco, sem viatura própria para abandonar rapidamente o local e retirar os seus haveres).

Por fim, são sobretudo pessoas com menor resiliência, ou seja, com menor capacidade de recuperar após a ocorrência do risco ${ }^{155}$. Nisso diferem dos grupos sociais privilegiados que, além de meios de comunicação e transporte, são pessoas que têm uma segunda habitação para se realojarem, têm seguros, têm outras fontes de rendimento, têm redes sociais fortes em que se podem apoiar ${ }^{156}$. Nada disto têm os "descidadãos" 157 , vítimas de múltiplas formas de exclusão social, como pessoas que vivem sós (idosos, deficientes) ou comunidades isoladas (imigrantes, grupos sociais marginalizados).

\subsection{Segundo momento: a construção social do risco e o nível adequado de protecção}

A propósito da construção social dos riscos concordamos com Michel Franc, quando afirma que «o tratamento jurídico do risco é antigo. 0 que é novo é a evolução dos próprios riscos e a percepção, pela sociedade, do risco admissível ou tolerado" ${ }^{158}$.

A intolerância social aos riscos ${ }^{159}$ resulta da evolução da percepção e da imagem social da Natureza, e da própria relação do Homem com a Natureza. Antigamente, nas percepções da vida e dos riscos, havia um "espaço para a fatalidade" ${ }^{160}$, mas actualmente as catástrofes

\footnotetext{
${ }_{154}$ Quem faz uma análise lúcida e incisiva desta realidade, especialmente nos Estados Unidos da América, é Susan L. Cutter, em Hazards, vulnerability and environmental justice, Earthscan, London, Sterling, VA, 2006.

${ }_{155}$ Siambabala Bernard Manyena, "The concept of resilience revisited", Disasters, ano 2006, vol 30 issue 4 p. 433 a 450. ${ }^{156}$ Nas populações desfavorecidas, a privação de alojamento, que é o resultado de uma exclusão económica, social e cultural, é também, um factor de exclusão, na medida em que pode constituir um obstáculo ao acesso das populações ao emprego, à educação, à protecção social ou à saúde. Françoise Zotouni, «Les Personnes Publiques Iniciatrices d'Operations d'Aménagement et l'Obligation de Relogement des Occupants», in: Mélanges en l'Honneur d' Henri Jacquot, Presses Universitaires d'Orléans, 2006, p. 597-616.

${ }^{157}$ Os conceitos de “descidadania” e de "cidadania responsável solidária” são desenvolvidos por Casalta Nabais,"que fala dos deveres que são assumidos pelos cidadãos em virtude do reconhecimento de que não são tarefa exclusivamente estadual, com vista à promoção da inclusão de todos os membros na comunidade ("Solidariedade Social, Cidadania e Direito Fiscal”, in: Estudos Jurídicos e Económicos em Homenagem ao Prof. Doutor António de Sousa Franco, vol II, Coimbra Editora, 2006, p. 642-645).

${ }_{158}$ «Traitement Juridique du risque et principe de précaution», in: Actualité Juridique Droit Administratif, n.ำ8, 3 Mars, 2003, p. 360.

159 Philippe Ségur refere, sobre a percepção social da catástrofe, que "a catástrofe faz nascer um consensus populi que exprime uma emoção partilhada perante os danos sofridos por uma parte da população" "«a catastrophe et le risque naturels: essai de définition juridique» in: Revue du Droit Public et de la Science Politique en France et a l'Étranger. - 0035-2578. - n. 6 (1997), p. 1704).

${ }^{160}$ Michel Franc, op. cit. p. 361.
} 
naturais deixaram de ser vistas como fatalidades ou castigos divinos ${ }^{161}$, perante os quais não restava ao Homem senão a resignação ${ }^{162}$, e passaram a ser vistos como fenómenos directa ou indirectamente influenciados pelas actividades humanas ${ }^{163}$ e, portanto, controláveis. Mesmo quando sejam puramente naturais, fenómenos de natureza catastrófica revelamse cada vez mais previsíveis e, em certa medida, preveníveis, sobretudo quando, pela sua repetitividade, se tornam antecipáveis.

Exemplificando: podemos não saber exactamente - ou sequer aproximadamente - quando ocorrerá uma grande inundação num rio, mas sabemos que, em média, de cem em cem anos, o rio transborda e atinge níveis ditos históricos, o que nos permite planear estratégicas de protecção antecipadas.

A evolução descendente do limiar da aceitabilidade social dos riscos é bem visível, hoje em dia, nas exigências, muito maiores, de segurança alimentar e de garantia quanto a produtos defeituosos, e na tolerância, muito menor, em relação à aleatoriedade dos cuidados médicos (a chamada álea médica) e aos riscos farmacêuticos.

\subsubsection{Aceitabilidade social do risco}

Trata-se agora de fazer uma ponderação autónoma da relação entre as vantagens e os inconvenientes, por um lado, e os níveis socialmente adequados de protecção, por outro.

Para este efeito, a participação pública é essencial. A participação deve ser precoce e alargada, ou seja, ocorrer desde os primeiros estádios do procedimento, envolvendo todas as partes potencialmente afectadas ou interessadas.

A importância e obrigatoriedade da participação do público encontram-se reforçadas desde a Convenção de Aarhus sobre Acesso à Informação, Participação do Público no Processo de Tomada de Decisão e Acesso à Justiça em Matéria de Ambiente ${ }^{164}$. Nela se prevê a participação do público em decisões sobre actividades específicas, em planos, programas e políticas em matéria de ambiente e na preparação de regulamentos e/ou instrumentos normativos legalmente vinculativos aplicáveis na generalidade ${ }^{165}$.

Correspondendo aos princípios da transparência e da abertura, a participação deve ser informada, precoce, alargada, plural, flexível, e útil ${ }^{166}$.

Esta é uma dimensão recente da governância dos riscos: a relevância atribuída aos cidadãos, leigos cuja opinião profana foi, desde sempre, desprezada e só recentemente, com a Convenção de Aarhus começou a ganhar algum estatuto.

\footnotetext{
${ }^{161}$ Valérie Sansseverino-Godfrin descreve com pormenor a influência, classicamente atribuída aos Deuses, sobre os fenómenos marítimos, meteorológicos e vulcânicos: Neptuno que revoltava as águas, Júpiter criava a tempestade e Vulcano fazia jorrar fogo das entranhas da Terra (Le cadre juridique de la gestion des risques naturels, Editions Tec Doc, Paris, 2008). Na mesma linha Abelkhaleq Berramdane chama a atenção para as referências bíblicas ao Dilúvio e à destruição de Sodoma e Gomorra e ainda para o muito difundido mito de Atlântida («L'Obligation de prévention des catastrophes et risques naturels», in: Revue du Droit Public et de la Science Politique en France et

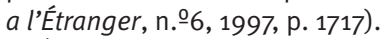

${ }^{162}$ É bem conhecida a influência do terramoto de 1755 sobre o pensamento filosófico europeu daquela época, ao desencadear uma célebre troca de ideias entre Voltaire e Rousseau, durante o ano de 1756, a propósito das origens, divinas ou humanas, da catástrofe que arrasou Lisboa.

${ }^{163}$ Para Philippe Ségur, "a questão da aceitabilidade social dos riscos resulta do reconhecimento da natureza antrópica de muitos riscos” («La catastrophe et le risque naturels. Essai de définition juridique», in: Révue du Droit Public et de la Science Politique en France et a l'Étranger, vol. 6, Novembre-Décembre, 1997, pp.1693-1716).

${ }^{164}$ Esta Convenção da Comissão Económica das Nações Unidas para a Europa foi celebrada em 1998, mas só entrou em vigor em 2001. Em Portugal foi aprovada pela Resolução da Assembleia da República n. ${ }^{0} 11 / 2003$, de 25 de Fevereiro. ${ }^{165}$ Artigos 6우 $7^{\circ}$ e 8ㅇ․

${ }^{166}$ Artigo 6을 da Convenção de Aarhus:

" 2 - O público interessado será informado de forma efectiva, atempada e adequada, quer através de notícia pública ou individualmente, conforme for mais conveniente, no início do processo de tomada de decisão, inter alia, sobre: a) A actividade proposta e o pedido sobre o qual será tomada a decisão;

b) A natureza das decisões possíveis ou o projecto de decisão;
}

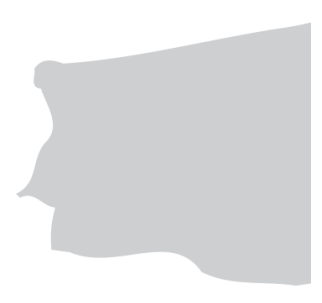


Desta forma, a legitimação social das decisões de gestão de riscos ${ }^{167}$ vem acrescer à legitimação científica, que muitas vezes cria uma mera "aparência de certeza", enquanto noutros casos "os inputs científicos têm a propriedade paradoxal de prometer, pela sua forma quantificada e numérica, objectividade e certeza mas acabam por produzir só maior desacordo quanto à substância"168. Mas a importância da percepção social do risco é directamente proporcional à incerteza científica que subsiste sobre uma determinada matéria. Quanto mais incerteza, maior a importância da construção social do risco.

A meio caminho entre as opiniões subjectivas dos cidadãos anónimos e as opiniões objectivas dos cientistas, surge agora uma nova classe de peritos que vem subverter, de certa forma, as regras da participação. De facto, com o aumento do poder das associações ecologistas, houve uma mudança quantitativa e qualitativa no papel dos peritos ${ }^{169}$ : primeiro, a multiplicação do número de "especialistas", e depois, o surgimento de uma nova categoria de peritos que, em vez de primarem pela neutralidade, assumem o comprometimento com uma causa ${ }^{170}$. Jane Hunt chega a advogar um novo estatuto para o conhecimento científico, que deixaria de ser o "árbitro final e objectivo" para se assumir como uma nova forma de conhecimento mais condicional e em busca de consensos ${ }^{171}$.

c) A autoridade pública responsável pela tomada de decisão;

d) 0 procedimento previsto, incluindo, como e quando esta informação pode ser fornecida:

i) 0 início do procedimento;

ii) As oportunidades de participação do público;

iii) A data e o local de qualquer consulta pública prevista;

iv) Indicação da autoridade pública que pode fornecer informação relevante e onde se encontra a informação para consulta do público;

v) Indicação da autoridade pública competente ou qualquer outro organismo público ao qual possam ser submetidos as perguntas ou comentários e o prazo de envio das perguntas ou comentários; e

vi) Indicação sobre que informação relevante em matéria de ambiente para a actividade proposta se encontra disponível;

3. - Os processos de participação do público devem incluir prazos razoáveis para as diferentes fases, de forma a permitir tempo suficiente para informar o público, de acordo com o disposto no parágrafo 2, e para que o público se possa preparar e participar efectivamente ao longo do processo de tomada de decisão em matéria de ambiente. 4 - Cada Parte tomará decisões para que a participação do público se inicie quando todas as opções estiverem em aberto e possa haver uma participação efectiva do público.

5- Cada Parte, quando apropriado, encorajará os futuros requerentes a identificar o público envolvido, a participar nas discussões e a fornecer informação relativa aos objectivos do seu pedido antes de ser concedida uma licença. 6 - Cada Parte solicitará às autoridades públicas competentes que autorizem o acesso do público interessado à consulta, quando solicitada nos termos da legislação nacional, de forma gratuita e logo que esteja disponível, de toda a informação relevante no processo de tomada de decisão

7 - Os procedimentos de participação do público devem permitir ao público, durante o inquérito ou audiência pública com o requerente, apresentar, por escrito ou como for conveniente, quaisquer comentários, informação, análises ou opiniões que este considere relevante para a actividade proposta.

8 - Cada Parte assegurará que, aquando da tomada de decisão, será tomado em devida conta o resultado da participação do público.

9-Cada Parte assegurará que, aquando da tomada da decisão pela autoridade pública, o público seja prontamente informado de acordo com o procedimento adequado. Cada Parte tornará acessível ao público o texto das decisões bem como das razões e considerações em que a decisão se baseou".

${ }^{167}$ Em sentido idêntico, defendendo que as normas jurídicas ambientais não podem sustentar-se exclusivamente no conhecimento pericial, Maria da Glória Garcia, O Lugar do Direito na Protecção do Ambiente, Almedina, Coimbra, 2007 , p. 402.

${ }^{168}$ Silvio Funtowicz, "Scienza e decisioni di polity", in: Notizi di Politeia, anno XIX, n. $.970,2003$, p. 28.

169 Silvio O. Funtowicz e Jerome R. Ravetz, falam da democratização da qualidade de perito ("democratization of the expertise"), ("Three types of Risk Assessment and the Emergence of Post-Normal Science", in: Social Theories of Risk, Sheldon Krimsky e Dominic Golding (Ed) Praeger, London, 1992, p. 253) p. 273).

${ }^{170}$ Geneviève Decrop, Jean-Pierre Galland, Claude Gilbert, «Les risques de l'Expertise» in: Actes d'Expertise et Responsabilités: le Risque de Montagne", Techniques, territoires et sociétés, Paris, Ministère de l'Équipement, des transports et du turisme, n. ${ }^{2} 28$, Janvier 1995, p.7-9.

${ }_{171}$ “The social construction of precaution", in: Timothy O'Riordan e James Cameron, (ed.) Interpreting the Precautionary Principle, Earthscan, 1994, p.125. 


\subsubsection{Percepção social do risco}

Cabe à Comissão Europeia o mérito de ter dado o devido destaque à percepção social dos riscos, na sua Comunicação sobre o princípio da precaução do ano $2000^{172}$. Mas mesmo numa sociedade social e culturalmente homogénea como é a europeia ${ }^{173}$, há grandes disparidades ao nível da percepção social dos riscos ${ }^{174}$. Os dados do Eurobarómetro sobre protecção civil ${ }^{175}$, tornam esta realidade bem perceptivel:
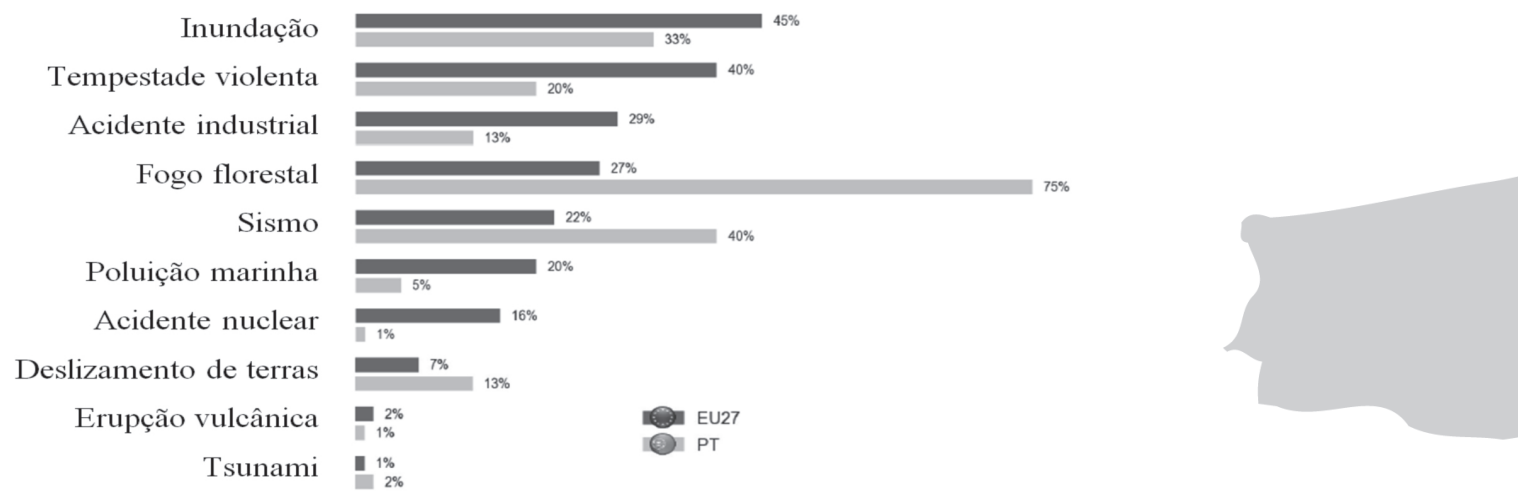

Reconhecendo a importância dos aspectos psico-sociais do risco, Cass Sunstein chama a atenção para o facto de o sentimento de insegurança e o pânico colectivo, mesmo quando provocados por um risco inexistente mas que se receia intensamente ${ }^{176}$, são males sociais a evitar. Por isso, o constitucionalista norte americano chega a interrogar-se sobre se, no caso de um risco não ser socialmente aceitável, mesmo quando as probabilidades de ocorrência do dano são baixas e as vantagens elevadas, se justificará a "compra da segurança regulatória"177.

\footnotetext{
172 "Diversos acontecimentos recentes mostraram que a opinião pública tem uma percepção acrescida dos riscos aos quais as populações ou o seu meio ambiente se expõem potencialmente. (...) As instâncias de decisão políticas têm o dever de ter em conta os temores relacionados com esta percepção e criar medidas preventivas para suprimir ou, pelo menos, limitar o risco a um nível mínimo aceitável”. (Comunicação..., p. 7)

${ }^{173}$ Em 2008, numa acção de incumprimento (processo C-165/08) instaurada pela Comissão Europeia, a Polónia invoca o princípio da precaução para justificar medidas nacionais proibindo a produção agrícola de organismos geneticamente modificados, com fundamento em razões de ordem moral, ética e religiosa. Alega, nomeadamente, que os polacos não aceitam de organismos geneticamente modificados porque são um povo muito religioso, que não gosta de modificar o que foi feito pela mão de Deus. Em 16 de Julho de 2009 o Tribunal não lhe deu razão e considerou que a Comissão Europeia já tinha tomado o risco em devida consideração nas várias directivas e decisões que autorizam a libertação voluntária no ambiente de organismos geneticamente modificados.

174 Michael Smithson confirma que quando se trata de analisar como as pessoas reagem à incerteza, a cultura pode ser determinante. Estudos psicológicos em matéria de risco, comparando as culturas ocidentais e asiática, têm revelado que ocidentais e orientais têm diferentes estilos cognitivos (Psychology's Ambivalent View of Uncertainty", in: Uncertainty and Risk. Multidisciplinary Perspectives, Earthascan, London, 2008, p.213-214).

${ }^{175}$ Edição especial n.ํㅜ 328, de Novembro de 2009.

${ }^{176}$ Foi muito citado o caso ocorrido em França em Abril de 2009, quando os membros de uma família de Saint-Cloud, após a instalação de uma antena retransmissora de telemóvel (da rede Orange) em frente à sua casa, começaram a manifestar sintomas de fadiga intensa, um sabor metálico na boca e hemoptises. Na sequência de um comunicado da operadora proprietária das antenas ficou provado que instalação das antenas não estava concluída, pelo que as antenas nunca tinham funcionado nem emitido qualquer radiação. (http://www.bestofmicro.com/actualite/26785antenne-relais.html)

177 Dando o exemplo dos seguros de assistência em viagem, Sunstein demonstra o importante efeito de criação de bem-estar. Antes de uma viagem é normal ficar ansioso e receoso de que o carro possa avariar. Mas se tiver um número de telefone para onde ligar a pedir ajuda (mesmo que na prática não ligue), isso é reconfortante. Por isso, ao subscrever um seguro de assistência em viagem estou a "comprar protecção contra os meus próprios receios", o que pode não fazer sentido em termos económicos, mas em termos de bem-estar faz todo o sentido (Worst Case Scenarios, Harvard University Press, Cambridge, 2007, p.141).
} 
Por outras palavras, devem os governantes tomar medidas legislativas ou administrativas só para pacificar a população, criando uma a reconfortante "ilusão do controlo" 178 ?

A resposta depende do grau de alarme social ${ }^{179}$ gerado em torno de um "não-risco", mas pensamos que mesmo nestes casos, os poderes públicos devem fazer alguma coisa ${ }^{180}$, nomeadamente promover a informação ambiental, a educação sobre prevenção de riscos, e o financiamento da investigação científica.

Parte da explicação para a discrepância entre a avaliação objectiva do risco e a percepção subjectiva do mesmo ${ }^{181}$, reside no facto de a tolerância social ao risco não depender apenas de factores objectivos e quantificados relativos ao risco ou aos danos (como a probabilidade, a magnitude ou a reversibilidade) mas de outros factores qualitativos ${ }^{182}$. Alguns foram identificados por Cass Sunstein em 2002 na obra Risk and Reason: safety, Law and the Environment ${ }^{183}$.

Por exemplo, a identificabilidade, tanto do agressor como da vítima, é um factor importante na reacção perante uma determinada ocorrência danosa. "Na realidade, antes da catástrofe só há números", diz expressivamente, Philippe Ségur ${ }^{184}$. Por isso, as pessoas respondem mais intensamente perante um ofensor identificável ou uma vítima identificável.

Citando Josef Stalin, Cass Sunstein descreve o sentimento social perante uma tragédia de grandes proporções: "uma morte é uma tragédia. Um milhão de mortes é estatística"185.

Alguns factores qualitativos funcionam como agravantes, "amplificando" riscos pouco graves ou pouco prováveis, e outros como atenuantes, criando uma habituação/aceitação mesmo de riscos graves e muito prováveis. Eis os principais factores agravantes ou atenuantes identificados por Sunstein:

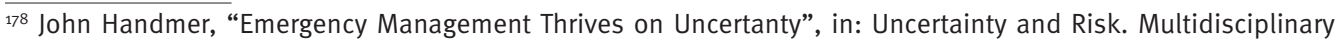
Perspectives, Earthascan, London, 2008, p. 237.

${ }^{179}$ No mesmo sentido, Gilles J. Martin: "Será necessário ir mais longe e defender que a dúvida é ainda legítima nos casos em que, independentemente de qualquer fundamento científico retirado das ciências exactas, a existência de uma percepção na sociedade - uma consciência partilhada - de risco pode ser constatada através de instrumentos de medidas das ciências sociais?" ("Principe de Précaution, Prévention des Risques et Responsabilité”, in: Actualité Juridique Droit Administratif, n.ํㅜㅇ, 28 Novembre 2005, p.2223).

${ }_{180}$ Sobre o Estado de Direito como educador na prevenção de riscos ver João Loureiro, "Da sociedade técnica de massas à sociedade de risco: prevenção, precaução e tecnociência - Algumas questões jurisprudenciais”, Boletim da Faculdade de Direito, Studia Jurídica, 61, 2000, p. 109.

${ }^{181}$ Philippe Ségur, fala da distinção entre "riscos reais" e "riscos percebidos” («La catastrophe et le risque naturels. Essai de définition juridique», in: Révue du Droit Public et de la Science Politique en France et a l'Étranger, vol. 6, Novembre-Décembre, 1997, pp.1693-1716).

${ }_{182}$ Stephen Dovers também defende que saber o que é uma "ameaça séria ou irreversível" depende de aspectos espaciais, da magnitude, longevidade, geribilidade, mas também da preocupação pública relativamente a ela e do entendimento do que é uma "ameaça séria ou irreversível" ("Precautionary policy assessment for sustainability", in: Implementing the Precautionary Principle. Perspectives and Prospects, Edward Elgar, Cheltenham, 2008, p.119). ${ }^{183}$ Cambridge University Press, 2002.

${ }^{184}$ «La catastrophe et le risque naturels: essai de définition juridique» in: Revue du Droit Public et de la Science Politique en France et a l’Étranger. - 0035-2578. - N. 6 (1997), p.1710.

185 Worst Case Scenarios, Harvard University Press, Cambridge, 2007, p. 63-64.
} 


\begin{tabular}{|c|c|c|}
\hline Factores & Agravantes & Atenuantes \\
\hline FAMILIARIDADE & Novo & Antigo \\
\hline CONTROLO PESSOAL & Incontrolável & Controlável \\
\hline VOLUNTARIEDADE & Involuntário & Voluntário \\
\hline ATENÇÃO DOS MEDIA & Muita atenção dos media & Ignorado pelos media \\
\hline EQUIDADE & Injustamente distribuído & Justamente distribuído \\
\hline CRIANÇAS & Crianças em especial risco & Sem crianças em risco \\
\hline GERAÇÕES FUTURAS & Em risco & Não em risco \\
\hline REVERSIBILIDADE & Irreversível & Reversível \\
\hline ASSUSTADOR & Especialmente assustador & Não muito assustador \\
\hline IDENTIFICABILIDADE DAS VÍTIMAS & Vítimas conhecidas & Vítimas não identificáveis \\
\hline VANTAGENS ASSOCIADAS & Vantagens claras & Vantagens não visíveis \\
\hline ORIGEM HUMANA OU NATURAL & Origem humana & Criado pela natureza \\
\hline CONFIANÇA NAS INSTITUIÇÕES & Falta de confiança & Bastante confiança \\
\hline TEMPO DOS EFEITOS & Diferidos & Imediatos \\
\hline COMPREENSÃO DO PROCESSO & Mecanismos não compreendidos & Mecanismos compreendidos \\
\hline HISTÓRIA PASSADA & Acidentes menores ou graves & Não há acidentes passados \\
\hline
\end{tabular}

Por outro lado, a avaliação da aceitabilidade social dos riscos depende também de ponderações subjectivas ${ }^{186}$, as quais podem ser motivadas por preconceitos, atitudes mais egoístas ou mais altruístas, etc.. Pior ainda é o facto de muita aceitação social ser devida simplesmente à ignorância dos riscos, à desinformação ou até às eventuais compensações que sejam previstas pelos promotores do projecto ou prometidas durante o processo ${ }^{187}$.

\footnotetext{
${ }_{186}$ Por exemplo, David Pearce explica que a "aversão aos desastres" é a razão pela qual as pessoas reagem de maneira diferente a um desastre em que morrem 10 pessoas ou a dez desastres em que morre uma pessoa. No total o número de mortes é o mesmo, mas a reaç̧ão social é bastante diferente ("The Precautionary Principle and Economic Analysis", in: Timothy O'Riordan e James Cameron, (ed.) Interpreting the Precautionary Principle, Earthscan, 1994, p. 134).

${ }^{187}$ A dificuldade que existe em relação à aceitabilidade social dos riscos, existe também em relação à aceitabilidade social das compensações. Se os cidadãos tendem a aceitar mais facilmente os riscos quando lhes são dadas, a título de compensação, outras vantagens ou formas alternativas de satisfação de necessidades, quem é que deverá pronunciar-se sobre o interesse que as gerações futuras possam ter numa determinada acção compensatória a desenvolver hoje? Será que esta substituição interessa às gerações futuras? Preferirão as gerações futuras viver num mundo cheio de estradas ou cheio de florestas? Ou então, imaginando que para compensar as perdas de habitats e de espécies resultantes da construção das estradas, se construíam zoos, gostariam eles de viver num mundo cheio de estradas e também de jardins zoológicos?
} 


\subsubsection{Nível adequado de protecção}

A consequência da participação é o dever de "tomar em consideração"188 os resultados da participação pública ${ }^{189}$. Mas este dever não significa que a opinião do público deva prevalecer em todos os casos. Quando a Comissão Europeia exprime a preocupação de "coerência" e "não discriminação" na escolha das medidas precaucionais, está também a sugerir que há limites na ponderação da aceitação social do risco. Se as sondagens mostrarem que a aceitação ou não aceitação de um risco resultarão num tratamento discriminatório ou incoerente, a percepção social dos riscos não pode prevalecer.

E não pode prevalecer sobretudo quando, na determinação da tolerabilidade dos riscos, as sondagens e as estatísticas muitas vezes trazem surpresas. Estamos a referir-nos, mais uma vez, às sondagens oficiais europeias sobre temas como as alterações climáticas, a clonagem ou a protecção civil, que são publicados no Eurobarómetro. Na análise destas sondagens o que se verifica é que nem sempre riscos elevados dão origem a uma grande intolerância social. Pode acontecer que um risco elevado seja, mesmo assim, socialmente aceitável ${ }^{190}$. E, o que também é frequente, pode acontecer o inverso - o risco ser baixo mas, mesmo assim, ser socialmente inaceitável ${ }^{191}$.

Este é o caso de certos projectos infra-estruturantes importantes - aterros, incineradoras de resíduos, aeroportos, hospitais, etc. - cuja existência é socialmente vantajosa, mas cuja localização é liminarmente recusada pelos residentes, em virtude dos incómodos de vizinhança, reais ou imaginados, que comportam.

"No meu quintal, não" (not in my backyard) é o lema mais frequente das manifestações populares ditas nimbyistas, que ocorrem quando os potenciais afectados pensam que, mesmo que a probabilidade de um risco se materializar seja muito baixa (uma probabilidade de um em um milhão, por exemplo), se o risco vier realmente a ocorrer, sabemos quem vai ser afectado: não serão os cientistas que avaliaram o risco, não serão os políticos que decidiram aquela localização, mas sim os trabalhadores (que convivem com ela oito horas por dia), os vizinhos (que passam grande parte da sua vida junto à instalação) e, em última instância, os componentes ambientais que não podem fugir.

Por tudo isto, não podem ser as gerações actuais a determinar, por sufrágio, o que é ou não aceitável para as gerações futuras ${ }^{192}$. Saber se um determinado risco é aceitável ou não, não pode depender apenas de sondagens de opinião, muito provavelmente favoráveis a actividades ou produtos envolvendo riscos graves, desde que os inconvenientes sejam

\footnotetext{
${ }_{188} \mathrm{O}$ reconhecimento da particular relevância social como fundamento do Recurso de Revista Excepcional para o Supremo Tribunal de Justiça, previsto, desde 2007, no artigo 721.-.A do Código de Processo Civil (" 1 - Excepcionalmente, cabe recurso de revista do acórdão da Relação referido no n. ${ }^{3}$ do artigo anterior quando: (...) b) Estejam em causa interesses de particular relevância social”) não será também um reconhecimento da relevância, cada vez maior, da opinião dos leigos nos processos judiciais e nas decisões jurídicas?

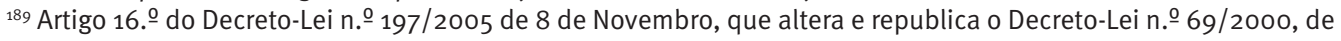
3 de Maio. "1-No prazo de 25 dias a contar da recepção do relatório da consulta pública, a comissão de avaliação, em face do conteúdo dos pareceres técnicos recebidos, da apreciação técnica do ElA, do relatório da consulta pública e de outros elementos de relevante interesse constantes do processo, elabora e remete à autoridade de AIA o parecer final do procedimento de AIA".

Artigo 9.ำ do Decreto-Lei n.. 232/2007, de 15 de Junho, sobre avaliação ambiental estratégica: "o relatório ambiental e os resultados das consultas realizadas nos termos dos artigos 7.0 e 8. do presente decreto-lei são ponderados na elaboração da versão final do plano ou programa a aprovar".

${ }^{190}$ Cass Sunstein dá o exemplo dos índices elevadíssimos de mortes nas estradas, consideradas como um risco socialmente aceitável...

${ }^{191}$ Exemplo disso são os receios quase irracionais em relação a certos poluentes atmosféricos como dioxinas e furanos, aos organismos geneticamente modificados, a todo e qualquer processo de co-incineração, etc..

192 Para Sonja Boehmer-Christiansen, "a precaução exige sobretudo uma sociedade capaz e desejosa de investir no futuro, sendo que essa necessidade não pode ser "provada" de antemão mas se mantém uma questão de fé" (“The Precautionary Principle in Germany,- Enabling Government”, in: Timothy O’Riordan e James Cameron, (ed.) Interpreting the Precautionary Principle, Earthscan, 1994, p. 57).
} 
futuros e os benefícios actuais. Agora o problema é saber quem é que tem que considerar o risco como aceitável ou não: na impossibilidade de sondar a opinião das gerações futuras, forçosamente serão as gerações actuais. Considerando a dificuldade de antever os desejos e aspirações das gerações futuras, alguns ordenamentos jurídicos optaram pela sua personificação, como aconteceu em 1993 em França, com a criação de uma instância consultiva de política legislativa, o Conselho para os Direitos das Gerações Futuras ${ }^{193}$. Mais recentemente, em 2007, na Hungria, foi criado o cargo de Comissário Parlamentar para as Gerações Futuras ${ }^{194}$. Em termos de representação judicial é bem conhecido o caso das crianças das Filipinas que, em 1993 instauram, no Supremo Tribunal de Manila, e em nome das gerações futuras, uma acção para proteger as florestas ${ }^{195}$. Mas, independentemente da representação institucional das gerações futuras, a grande dificuldade reside na previsão de quais possam ser as legítimas aspirações dessas gerações...

Ora, o nível adequado de protecção é a materialização das presumíveis expectativas das gerações futuras, e deve ser definido pelos poderes políticos ${ }^{196}$, $\operatorname{com}$ base noutros elementos além das opiniões do público.

Se a avaliação do risco é eminentemente científica, a definição da aceitabilidade do risco, e consequentemente do nível adequado de protecção, é uma decisão essencialmente ética ${ }^{197}$ e política ${ }^{198}$.

Deste modo, um risco deve ser considerado inaceitável, se violar o que consideramos serem os deveres das gerações actuais para com as gerações futuras. Quando esteja em causa a protecção do ambiente e da saúde pública, é a própria ordem jurídica Europeia que define o nível de protecção ${ }^{199}$, o qual deve ser elevado. Este é um aspecto constitucional da Política Europeia do Ambiente ("A política da União no domínio do ambiente terá por objectivo atingir um nível de protecção elevado, tendo em conta a diversidade das situações existentes nas diferentes regiões da União", lê-se no artigo 191, n.․2 do Tratado sobre o Funcionamento da União), e um ponto especialmente enfatizado pela Comissão Europeia, na Comunicação de Fevereiro de 2000.

Em termos ambientais ${ }^{200}$ não são aceitáveis, por exemplo, quaisquer riscos que impliquem perdas irreversíveis. Concretizando, a nível da biodiversidade, são inaceitáveis actividades que possam originar extinções de espécies, perdas de habitats naturais prioritários (endémicos ou característicos de uma região biogeográfica) ou, quanto aos bens abióticos, o esgotamento total de um recurso mineral. Para Nicolas de Sadeleer, "quando o risco ameaça

\footnotetext{
${ }^{193}$ Criado pelo Decreto n.ํㅜ 93-298, de 8 de Março.

${ }^{194}$ Após longa discussão parlamentar foi escolhido o nome de Sándor Fülöp, eleito em 28 de Maio de 2008 para ocupar o cargo de Comissário Parlamentar para as gerações futuras até 2014 (mais informação disponível em http://jno.hu/en).

${ }^{195}$ Caso Oposa v. Factoran, disponível em http://www.lawphil.net.

${ }^{196}$ Fora da área jurídica, negando o papel da política na determinação do nível adequado de protecção, José Delgado Domingos, em "Por uma sociedade com menos CO2" (in: A energia da Razão. Por uma sociedade com menos CO2, Gradiva publicações, Lisboa, 2009, p. 153 a 211).

197 Alain Thomasset, professor de teologia moral, frisa que a ética contemporânea da responsabilidade supõe "um novo «hábito» alimentado de prudência e de sabedoria, que se traduz no dever de respeitar o princípio da precaução, como uma primeira injunção moral. Nesta acepção, o princípio da precaução consistiria em, antes de agir, "nos preocuparmos com os efeitos longínquos ou indirectos, mas previsíveis, dos nossos poderes” (De la prudence à la précaution. Vers une étique du risque, in: http://www.ceras-projet.com Julho de 2006, p. 3).

${ }^{198}$ Esta é também a posição de David Byrne, na presentação da Comunicação da Comissão sobre o Princípio da Precaução perante o Parlamento Europeu, em 2000.

${ }^{199}$ Claro que o estabelecimento de níveis elevados de protecção ambiental e a adopção de rigorosas medidas precaucionais, têm custos. Sobre os custos dos direitos fundamentais ver (Casalta Nabais,"A Face Oculta dos Direitos Fundamentais: os Deveres e os Custos dos Direitos", in: Estudos em Homenagem ao Conselheiro José Manuel Cardoso da Costa, Coimbra Editora, 2003, p. 737-792).

${ }^{200}$ Não estamos a pensar em danos ambientais, como danos em bens jurídicos humanos patrimoniais ou extrapatrimoniais, mas apenas em danos ecológicos, ou seja danos ambientais puros.
}

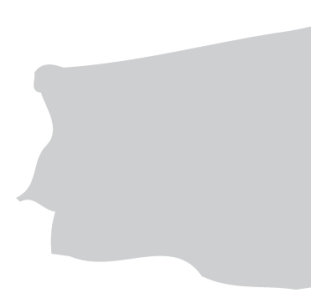


produzir algo irreparável ou comprometer as faculdades naturais essenciais, ele deve ser esconjurado, porque é inaceitável"201.

Já em termos sociais, não são aceitáveis os riscos que afectem essencialmente os sectores populacionais ou grupos sociais mais frágeis. Por exemplo: se a maioria dos indivíduos potencialmente afectados pertencerem a uma etnia, religião ou cultura minoritárias, ou se forem populações economicamente carenciadas e menos resilientes nos termos que referimos anteriormente.

Em suma, o princípio da precaução não se destina só a evitar os riscos que são considerados graves e irreversíveis por uma parte significativa da comunidade científica, mas também os que são sentidos como intoleráveis e injustos pela generalidade dos cidadãos (em função da avaliação da percepção social do risco), e ainda os que sejam considerados inaceitáveis pelos poderes políticos (em função da definição do nível de protecção adequado). Estas são as três fontes materiais das medidas precaucionais.

\subsection{Terceiro momento: escolha das medidas precaucionais}

Diagnosticada a incerteza e a importância do dano, que justificam o recurso à precaução, seguidos os trâmites de ponderação objectiva (vantagens e inconvenientes) e subjectiva (aceitabilidade social) do risco, resta a escolha das medidas a tomar.

Como já vimos, na governância dos riscos, a escolha das medidas precaucionais, além de contribuir para evitar os danos, tem também uma função importante de pacificação social (a “compra da segurança regulatória”, de que fala Sunstein). Mas a intensidade das medidas precaucionais pode também ter um efeito negativo importante: se, com o tempo, o risco não se confirmar, tal facto pode contribuir para descredibilizar as estratégias precaucionais. Daí a importância da escolha e aplicação correcta das medidas precaucionais.

\subsubsection{Medidas urgentes}

Em matéria de riscos ambientais, globais, retardados e irreversíveis, a inércia é má conselheira. As medidas devem ser tomadas urgentemente. Nas palavras de Lester Brown,

Apesar de os riscos serem retardados, apesar de a causalidade ser difícil de estabelecer, apesar de a proporcionalidade ser difícil de avaliar, as medidas não podem ser adiadas. A gravidade ${ }^{202}$ das consequências explica a urgência das medidas evitatórias.

A urgência é um conceito importante a ter em consideração na determinação das medidas proporcionais: não é só a gravidade, magnitude, reversibilidade, mas também a iminência do dano, que conduz à urgência das medidas. Se um efeito ambiental nocivo está quase a acontecer, não é razoável pedir tempo para fazer estudos com vista a obtenção de certezas científicas dos nexos e meios de prova dos danos...

\subsubsection{Medidas provisórias}

Uma característica das medidas precaucionais, que são tomadas com a consciência da incerteza e apesar dela, é não poderem nunca ser medidas definitivas. Pelo contrário, são sempre medidas provisórias, susceptíveis de revisão, e que devem efectivamente ser revistas com uma periodicidade curta ou sempre que surjam novos dados científicos. Quanto ao tempo de vigência, as medidas precaucionais são, portanto, medidas com "prazo de validade" curto, adoptadas através de procedimentos participados e iterativos.

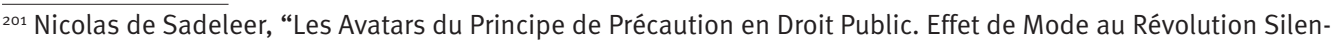
cieuse?» in: Revue Française de Droit Administratif, 2001, Mai-Juin, p.560.

${ }^{202}$ Um critério possível de análise da gravidade das consequências é o número de "anos potenciais de vida perdidos". Segundo Catherine Herbert, (in: Dictionaire des Risques, Yves Dupont (dir), Armand Colin, Paris, 2007, p.33) este é um indicador de saúde pública que permite calcular, ao nível colectivo, o número de anos de vida perdidos por uma população sujeita a um determinado evento, num determinado tempo.
} 
Deste modo, a revisão periódica das medidas implica o desenvolvimento de investigação científica, com vista ao aprofundar dos conhecimentos sobre a actividade, o produto ou a tecnologia em causa.

Por isso, um dever acessório de todas as medidas provisórias de carácter autorizativo, fundadas no princípio da precaução, é o dever de investigação científica. Quanto mais forte e restritiva for a medida de precaução, em relação à actividade considerada, mais a produção de conhecimentos deverá ser vista como urgente e juridicamente vinculativa ${ }^{203}$.

Já no caso das proibições provisórias, baseadas no princípio da precaução, a investigação científica passa a ser um ónus do interessado na autorização da actividade. Porém, no processo de determinação de factos e de obtenção de provas, a produção de informação pela parte interessada, se tiver motivação económica suficiente para fazer grandes investimentos na obtenção de dados, potencialmente pode originar informação tendenciosa, ou pelo menos percebida como tal ${ }^{204}$.

De qualquer forma há aqui uma deslocação da responsabilidade, quanto à produção de novas provas científicas: o regime da autorização prévia inverte o ónus da prova ${ }^{205}$. In dubio pro ambiente é a expressão que, sinteticamente, exprime esta ideia.

Idealmente, o que acontecerá é que, após algumas iterações, quando a incerteza científica se dissipar, uma decisão tornar-se-á definitiva. A matéria em causa passa então a ser regulada pelo princípio da prevenção. Eis como o princípio da precaução promove directamente o progresso científico num contexto de "ciência pós-normal" 206 .

\subsubsection{Medidas proporcionais}

A última característica das medidas decorrentes do princípio da precaução é deverem ser proporcionais. A proporcionalidade tem, em todo o processo de aplicação do princípio da precaução, um papel-chave. Mas se a proporcionalidade pressupõe uma comparação seguida de uma ponderação, quais são aqui os elementos a ter em consideração?

As medidas devem ser proporcionais às ponderações feitas anteriormente:

a) por um lado, às vantagens e inconvenientes (ambientais, sociais e económicos) que decorrem da autorização da actividade, da aprovação do produto ou da aplicação da tecnologia;

b) por outro, ao nível de protecção definido como adequado, pelos poderes públicos (e que pode não corresponder à aceitabilidade social do risco, como já vimos antes).

Agora, para efeito de escolha das medidas, não relevam nem a gravidade absoluta dos danos potenciais, nem a eventual falta de consenso científico quanto aos riscos. Interessa, sim, atender a toda a ponderação previamente feita quanto à compatibilidade da decisão final com o desenvolvimento sustentável, nas suas vertentes ambiental, social e económica.

Se as vantagens da actividade, produto ou tecnologia forem mínimas, os inconvenientes, forem significativos e o nível de protecção exigido, for elevado, então a medida proporcional e adequada poderá ser uma proibição tout court.

\footnotetext{
${ }^{203}$ Gilles J. Martin, “Principe de Précaution, Prévention des Risques et Responsabilité”, in: Actualité Juridique Droit Administratif, n.ำ- 28 Novembre 2005, p.2224.

204 Judith S. Jones, "Certainty as Illusion: The Nature and Purpose of Uncertainty in the Law", in: Uncertainty and Risk. Multidisciplinary Perspectives, Earthascan, London, 2008, p. 275.

${ }^{205}$ Para Nicolas de Sadeleer, mais importante do que saber quem tem o ónus da prova do risco ou da sua ausência, é saber quem deve pagar os custos das avaliações levadas a cabo pelas autoridades públicas. Na sua opinião, só o princípio do poluidor pagador pode responder a esta questão (“Les Avatars du Principe de Précaution en Droit Public. Effet de Mode au Révolution Silencieuse?» in: Revue Française de Droit Administratif, 2001, Mai-Juin, p. 554). ${ }^{206}$ Conceito cunhado por Silvio Funtowicz (por contraposição ao conceito de "ciência normal" de Thomas Khun) para caracterizar o método de análise necessário quando os factos são incertos, os valores são controversos, os riscos elevados e as decisões urgentes (Silvio O. Funtowicz e Jerome R. Ravetz, "Three types of Risk Assessment and the Emergence of Post-Normal Science, in: Social Theories of Risk, Sheldon Krimsky e Dominic Golding (ed) Praeger, London, 1992, p. 253 e também “Scienza e decisioni di polity", in: Notizi di Politeia, anno XIX, n.ํ70, 2003, p.25).
} 
No outro extremo, se as vantagens da actividade, produto ou tecnologia forem muito significativas, os inconvenientes, reduzidos, e o nível de protecção exigido, baixo, poderão bastar simples deveres de informação, dos clientes ou vizinhos maxime, através do rótulo do produto ou de dísticos adequados afixados em local visível.

Entre os dois extremos, outros exemplos de medidas precaucionais ${ }^{207}$ de intensidade variáve ${ }^{208}$ são: moratórias, autorizações precárias e por prazos $\operatorname{curtos}^{209}$, respeito da regra ALARA $^{210}$, substituição de produtos, exigência de garantias financeiras, redução do tempo de exposição a produtos ou emissões, deveres de monitorização e auto-controlo, deveres de notificação para aumentar a rastreabilidade, deveres de registo (de produtos, actividades, etc.) ou simples recomendações para a população exposta ao risco ${ }^{211}$.

Ao nível administrativo, as medidas adequadas podem consistir na alteração de procedimentos, no envolvimento de entidades especializadas, na criação de órgãos de natureza científica com poderes consultivos ou deliberativos, na generalização de procedimentos de pós-avaliação, na aprovação de planos de prevenção de riscos ${ }^{212}$, etc..

${ }^{207}$ Filipa Urbano Calvão faz uma análise sistemática das diversas formas de actuação da administração na protecção do ambiente, com especial incidência nas actuações preventivas ("As Actuações Administrativas no Direito do Ambiente", Direito e Justiça, Vol. XIV Tomo 3, 2000, p. 121 a 146).

${ }^{208} \mathrm{Na}$ escolha entre as diferentes abordagens jurídicas possíveis, é útil ter em mente a construção de Catherine Thibierge a propósito do "soft law" (traduzido para francês como "le droit souple"). A autora propõe uma "dupla escala" quanto à "suavidade da força".

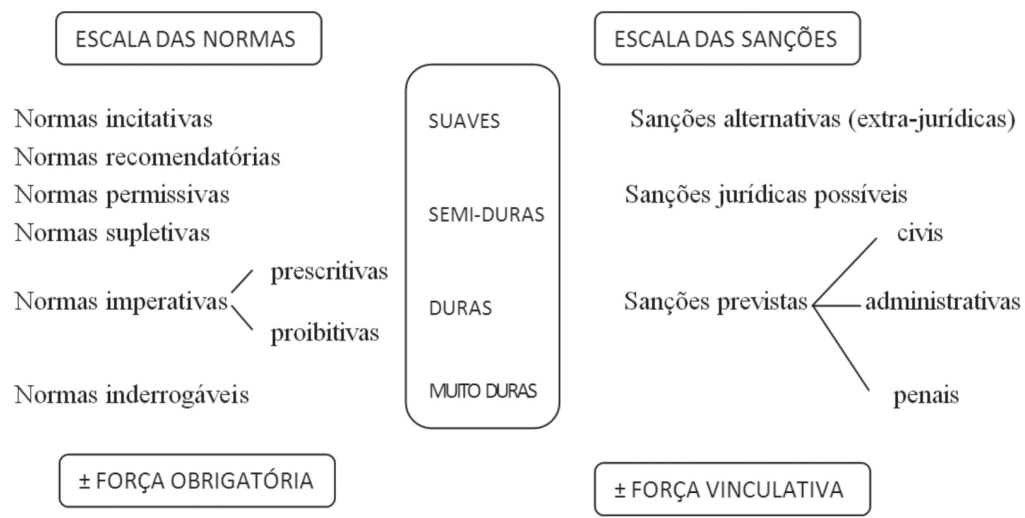

«Le Droit Soupe. Réflexions sur les Textures du Droit», in: Révue Trimestrielle de Droit Civil, Octobre, Décembre 2003 , p. 617.

${ }^{209}$ Cécile Castaing apresenta esta ideia de uma forma sugestiva: “a medida de precaução não é um fim em si mesma e parece, pelo contrário, votada à efemeridade: é uma medida que deve ser provisória, à espera que o conhecimento científico disponível se afine", "La mise en oeuvre du príncipe de précaution dans le cadre du référé suspension", in: Actualité Juridique Droit Administratif, nํ43, 15 Décembre, 2003, p. 2291.

Sobre os actos administrativos não definitivos no Direito Administrativo, ver o estudo de Filipa Urbano Calvão Os actos precários e os actos provisórios no direito administrativo: sua natureza e admissibilidade: as garantias do particular, Universidade Católica Portuguesa, Porto, 1998.

${ }^{210} \mathrm{Em}$ matéria de substâncias perigosas, a regra é reduzir a sua utilização até ao nível mais baixo possível: "as low as reasonably achievable".

${ }^{211}$ Por exemplo a Recomendação 90/143/Euratom, de 21 de Fevereiro de 1990, relativa à protecção da população contra a exposição interior ao radão, gás radioactivo que ocorre naturalmente em zonas graníticas. "Embora actualmente não existam provas sólidas relativas aos efeitos da exposição interior ao radão sobre o público em geral", mas considerando que se suspeita que possa estar na origem de cancro do pulmão e que o radão interior é tecnicamente controlável, a Comissão Europeia recomenda, desde 1990, que a construção de edifícios de habitação em zonas graníticas tenha este fenómeno em consideração.

${ }^{212}$ Jean-Marie Pontier caracteriza os planos de prevenção de riscos como instrumentos “previsionais" e não decisórios, "na fronteira da normatividade”, que se multiplicam no domínio da prevenção e gestão de riscos, («Le droit de la prévention des risques, droit en devenir des sociétés développées, d'aujourd'hui et de demain», in Les plans de prévention des risques, Université Paul Cézanne- Aix Marseille III, 2007, p. 61). Especificamente sobre a natureza 
Embora a "compra da segurança regulatória", não possa ser nunca o objectivo primário, concordamos que um efeito secundário desejável da aplicação das medidas precaucionais, sobretudo se elas forem amplamente divulgadas, é a consciencialização social do risco ${ }^{213}$, a qual, por sua vez, gera primeiro, uma maior preparação para reagir ao risco, se ele se vier a concretizar ${ }^{214}$; e segundo, o aumento da confiança, e portanto do bem-estar social, relativamente à sobrevivência numa sociedade de riscos.

Por outras palavras, se é verdade que "quem não arrisca não petisca”, também é um facto que, arriscando com plena consciência dos riscos, e adoptando medidas preparatórias para os enfrentar, não só ganhamos em tranquilidade como, se o risco se vier a concretizar, os impactes serão certamente menores ${ }^{215}$.

\section{Conclusão}

Princípio intrinsecamente ligado aos novos tempos do direito ambiental, o princípio da precaução é, por excelência, um instrumento de realização do desenvolvimento sustentável. Preocupações ambientais, sociais e económicas perpassam os vários momentos de aplicação do princípio.

Proteger as gerações actuais e futuras contra riscos globais, retardados e irreversíveis é um imperativo ao qual o princípio da precaução parece dar uma resposta adequada.

Este princípio corresponde hoje "tanto a uma vontade política como a uma necessidade jurídica" 216 e da sua aplicação resultam, pois, políticas de gestão de riscos realistas ${ }^{217}$, prudentes e praticáveis.

0 respeito dos princípios fundamentais da governância na aplicação do princípio, envolvendo toda a sociedade, reforça a aceitabilidade social de decisões onerosas, cujas vantagens, muitas vezes, só serão sentidas no futuro.

Em suma, com Olivier Godard, diríamos que a precaução evoluiu de um "conceito técnico que criou o seu espaço no mundo organizado da gestão de riscos, para um conceito pivot de uma mudança radical, desejada ou receada, dos valores fundamentais da sociedade" ${ }^{218}$.

\section{Alexandra Aragão \\ Professora Auxiliar da Faculdade de Direito da Universidade de Coimbra}

\footnotetext{
e características dos planos de exposição aos riscos, ver Raphael Romi, «Risque et droit quelles problématiques?» in: La prévention des risques naturels, échec ou réussite des Plans d'exposition aux risques?, Université de Nice Sophie Antipolis, 1993, p. 23 e ss.

${ }^{213}$ Em França o Ministério da Ecologia e do Desenvolvimento Sustentável desenvolveu um "Guia de Concertação entre - Estado e as Colectividades Territoriais Relativamente aos Planos de Prevenção dos Riscos Naturais Previsíveis", Ministère de l'Écologie et du Développement Durable, Plans de Prévention de Risques Naturels Prévisibles. Guide de la concertation entre l'Etat et les collectivités territoriales. Paris, Décembre 2003.

${ }^{214}$ "De facto, o nível de danos não é apenas função da intensidade desta última [a catástrofe] mas de múltiplos factores como a adequação dos meios de protecção, os planos de evacuação, a instrução e rapidez de intervenção dos salvadores, da qualidade e flexibilidade da gestão, do grau de informação prévia sobre as vítimas, etc. Neste caso, a apreensão do risco catastrófico determina em certa medida a extensão da própria catástrofe" (Philippe Ségur, «La catastrophe et le risque naturels - essai de définition juridique» in: Revue du Droit Public et de la Science Politique en France et a l’Étranger. - 0035-2578. - N. 6 (1997), p. 1714-1715).

${ }^{215}$ José Manuel Mendes e Alexandre Tavares mostram, através do caso concreto da região centro em Portugal, que a consciência do risco e a preparação para o risco influenciam negativamente a magnitude dos danos. "Building Resilience to Natural Hazards. Practices and Policies on Governance and Mitigation in the Central Region of Portugal", in: Safety, Reliability and Risk Analysis: Theory, Methods and Applications, Martorell et al. (eds), Taylor \& Francis Group, London, 2009, p. 1577 a 1584.

${ }^{216}$ Cécile Castaing, "La mise en oeuvre du príncipe de précaution dans le cadre du référé suspension”, in: Actualité Juridique Droit Administratif, n²04, 15 Décembre 2003, p.2297.

${ }^{217}$ "Colocada num contexto construtivo e habilitador, a precaução pode funcionar como um catalizador com um valor incalculável no reconhecimento do papel adequado da ciência numa era em que a incerteza é reconhecida pelo que é: um indicador prudente da falibilidade humana na construção do seu mundo". (Timothy O'Riordan e James Cameron, (ed.) Interpreting the Precautionary Principle, Earthscan, 1994, p. 68).

${ }^{218}$ Le principe de precaution, in: http://www.ceras-projet.com Julho de 2006, p. 4.
} 


\section{ANEXO}

Decreto-lei n. $.96 / 2000$ de 3 de Maio

(alterado e republicado pelo Decreto-lei n.ำ197/2005 de 8 de Novembro)

\section{ANEXO V}

Critérios de selecção referidos nos n.0s 4 e 5 do artigo 1.은

1-Características dos projectos-as características dos projectos devem ser consideradas especialmente em relação aos seguintes aspectos:

Dimensão do projecto;

Efeitos cumulativos relativamente a outros projectos;

Utilização dos recursos naturais;

Produção de resíduos;

Poluição e incómodos causados;

Risco de acidentes, atendendo sobretudo às substâncias ou tecnologias utilizadas.

2-Localização dos projectos-deve ser considerada a sensibilidade ambiental das zonas geográficas susceptíveis de serem afectadas pelos projectos, tendo nomeadamente em conta:

A afectação do uso do solo;

A riqueza relativa, a qualidade e a capacidade de regeneração dos recursos naturais da zona;

A capacidade de absorção do ambiente natural, com especial atenção para as seguintes zonas:

a) Zonas húmidas:

b) Zonas costeiras;

c) Zonas montanhosas e florestais;

d) Reservas e parques naturais;

e) Zonas classificadas ou protegidas, zonas de protecção especial, nos termos da legislação;

f) Zonas nas quais as normas de qualidade ambiental fixadas pela legislação nacional já foram ultrapassadas;

g) Zonas de forte densidade demográfica;

h) Paisagens importantes do ponto de vista histórico, cultural ou arqueológico.

3-Características do impacte potencial-os potenciais impactes significativos dos projectos deverão ser considerados em relação aos critérios definidos nos n.os 1 e 2 supra, atendendo especialmente à:

Extensão do impacte (área geográfica e dimensão da população afectada);

Natureza transfronteiriça do impacte;

Magnitude e complexidade do impacte;

Probabilidade do impacte;

Duração, frequência e reversibilidade do impacte 


\section{Bibliografia citada}

Agência Europeia do Ambiente - Late Lessons from Early Warnings: the Precautionary Principle 1896-2000, Copenhagen, 2001.

Aragão, Alexandra - O Princípio do Poluidor Pagador, Pedra Angular da Política Comunitária do Ambiente, Studia luridica, nํ23, Coimbra Editora, 1997.

Bammer, Gabriele e Michael Smithson (ed.) - Uncertainty and Risk. Multidisciplinary Perspectives, Earthascan, London, 2008.

Berramdane, Abelkhaleq - «L'Obligation de prévention des catastrophes et risques naturels», in: Revue du Droit Public et de la Science Politique en France et a l'Étranger, n. $\stackrel{9}{6}, 1997$, p. 1717.

Boehmer-Christiansen, Sonja - “The Precautionary Principle in Germany,- Enabling Government”, in: Timothy O'Riordan e James Cameron, (ed.) Interpreting the Precautionary Principle, Earthscan, 1994.

Brown, Lester - Plan B 2.0, Rescuing a Planet Under stress and a Civilization in Trouble, Earth Policy Institute, W.W. Norton \& Company, New York, 2006.

Calvão, Filipa Urbano - “As Actuações Administrativas no Direito do Ambiente”, Direito e Justiça, Vol. XIV Tomo 3, 2000, p. 121 a 146.

Calvão, Filipa Urbano - Os actos precários e os actos provisórios no direito administrativo: sua natureza e admissibilidade: as garantias do particular, Universidade Católica Portuguesa, Porto, 1998.

Canotilho, José Joaquim Gomes - “Estado Constitucional Ecológico e Democracia Sustentada”, in: RevCEDOUA, n요 8, ano IV, 2, 2001.

Castaing, Cécile - “La mise en oeuvre du príncipe de précaution dans le cadre du référé suspension”, in: Actualité Juridique Droit Administratif, nㄴ4, 15 Décembre 2003, p. 2291.

Cooney, Rosie - "A Long and Winding road? Precaution from Principle to Practice in Biodiversity Conservation", in: Implementing the Precautionary Principle. Perspectives and Prospects, Edward Elgar, Cheltenham, 2008.

Correia, Fernando Alves - “Risco e Direito do Urbanismo", in: Revista de legislação e Jurisprudência, n. ${ }^{\circ}$ 3955, Março-Abril 2009.

Correia, Sérvulo - "O Incumprimento do Dever de Decidir", in: Estudos Jurídicos e Económicos em Homenagem ao Prof. Doutor António de Sousa Franco, vol II, Coimbra Editora, 2006.

Crescenzo-d'Auriac, Marie-Béatrix - procura definir o limiar a partir do qual uma ocorrência assume dimensões catastróficas Les Risques Catastrophiques, Évènements NaturelsP politiques et Technologiques, L’Argus, Paris, 1988.

Cutter, Susan L. - Hazards, vulnerability and environmental justice, Earthscan, London, Sterling, VA, 2006.

Davy, Benjamin - Essential injustice: when legal institutions cannot solve environmental and land use disputes, Springer-Verlag, Wien, New York, 1997.

Decrop, Geneviève, Jean-Pierre Galland e Claude Gilbert, - «Les risques de l'Expertise» in: Actes d'Expertise et Responsabilités: le Risque de Montagne", Techniques, territoires et sociétés, Paris, Ministère de l’Équipement, des transports et du turisme, n.ํㅡㄹ, Janvier 1995.

Dictionaire des Risques, Yves Dupont (dir), Armand Colin, Paris, 2007.

Domingos, José Delgado - "Por uma sociedade com menos CO2" in: A energia da Razão. Por uma sociedade com menos $\mathrm{CO}_{2}$, Gradiva publicações, Lisboa, 2009.

Dovers, Stephen - "Precautionary policy assessment for sustainability”, in: Implementing the Precautionary Principle. Perspectives and Prospects, Edward Elgar, Cheltenham, 2008.

Favret, Jean-Marc - «Le principe de précaution ou la prise en compte par le droit de l'incertitude scientifique et du risque virtuel», in: Dalloz, 6 Décembre, 2001, p. p. 3463.

Fisher, Elisabeth Judith Jones e René von Schomberg, - Implementing the Precautionary Principle. Perspectives and Prospects, Edward Elgar, Cheltenham, 2008.

Franc, Michel - «Traitement Juridique du risque et principe de précaution», in: Actualité Juridique Droit Administratif, n. $-8,3$ Mars, 2003, p. 360.

Fuller, Buckminster - Manual de Instruções para a Nave Espacial Terra, Porto, Via Óptima, 1998.

Funtowicz, Silvio O. e Jerome R. Ravetz, - "Scienza e decisioni di polity”, in: Notizi di Politeia, anno XIX, n. $.90,2003$, p.29 a 30 .

Funtowicz, Silvio O. e Jerome R. Ravetz, - “Three types of Risk Assessment and the Emergence of PostNormal Science", in: Social Theories of Risk, Sheldon Krimsky e Dominic Golding (Ed) Praeger, London, 1992. Garcia, Maria da Glória - O Lugar do Direito na Proteç̧ão do Ambiente, Almedina, Coimbra, 2007. 
Godard, Olivier - “The Precautionary Principle and Catastrophism on tenterhooks: lessons from a constitutional reform in France", in: Implementing the Precautionary Principle. Perspectives and Prospects, Edward Elgar, Cheltenham, 2008.

Gomes, Carla Amado - A Prevenção à Prova no Direito do Ambiente. Em Especial, os Actos Autorizativos Ambientais, Coimbra Editora, 2000.

Gros, Manuel e David Deharbe, - "La Controverse du Principe de Précaution”, in: Revue du Droit Public et de la Science Politique en France et à l'Étranger, Mai-Juin 2002, nํㅜㅇ.

Jonas, Hans - Le principe de responsabilité. Une éthique pour la civilisation technologique, Ed. Champs, Flammarion, Paris, 1999.

Jones, Judith e Simon Bronitt, - “The Burden and Standard of Proof in Environmental Regulation: the Precautionary Principle in an Australian Administrative Context”, in: Implementing the Precautionary Principle. Perspectives and Prospects, Edward Elgar, Cheltenham, 2008. Jousse, Georges - Traité de riscologie - La science du risque, Imestra Éditions, 2009.

Kiss, Alexandre - "L’Irreversibilité et le Droit dês Generations Futures”, in: Révue Juridique de l’Environnement, numéro spécial, 1998, p. 52.

Ladourie, Emmanuel le Roy - «L'historien face à l'histoire climatique et à l'attitude des autorités en cas de conjoncture "climatico-perilleuse»", in Les pouvoirs publics face aux risques naturels dans l'histoire. Publications de la MSH-Alpes, 2005.

Landis, Michel - "Fate, Responsability and "Natural” Disaster Relief: Narrating the American Welfare State”, in: Law and Society Review, vol 33, n.ํㅡ 1999, p. 263.

Latour, Bruno - Politiques de la nature. Comment faire entrer les sciences en démocratie. Paris, La Découverte, 1999.

Löfstedt, Ragnar E. - "The Swing of the Regulatory Pendulum in Europe: From Precautionary Principle to (Regulatory) impact analysis”, in: The Journal of Risk and Uncertainty, 28:3, 2004, p. 237-260. Loureiro, João - "Da sociedade técnica de massas à sociedade de risco: prevenção, precaução e tecnociência - Algumas questões jurisprudenciais”, Boletim da Faculdade de Direito, Studia Jurídica, 61, 2000. Manyena, Siambabala Bernard - “The concept of resilience revisited”, Disasters, ano 2006, vol 30 issue 4 p.433 a 450.

Martin, Gilles J. - “Principe de Précaution, Prévention des Risques et Responsabilité”, in: Actualité Juridique Droit Administratif, n. ${ }^{-} 40,28$ Novembre 2005, p. 2223.

Martin, Pierre - Ces Risques que l'on Dit Naturels, Eyrolles, Paris, 2006.

Meadows, Donella, Denis Meadows e Jorgen Rangers, - Além dos limites. Da catástrofe total ao futuro sustentável, Difusão Cultural, Lisboa, 1993.

Mendes, José Manuel e Alexandre Tavares, - "Building Resilience to Natural Hazards. Practices and Policies on Governance and Mitigation in the Central Region of Portugal”, in: Safety, Reliability and Risk Analysis: Theory, Methods and Applications, Martorell et al. (eds), Taylor \& Francis Group, London, 2009. Michelot, Agnès - "Utilization durable et irreversibilité(s). Du «jeu» de la temporalité aux enjeux de la durabilité», in: Révue Juridique de l'Environnement, numéro spécial, 1998, p.36.

Ministère de l'Écologie et du Développement Durable, - Plans de Prévention de Risques Naturels Prévisibles. Guide de la concertation entre l'Etat et les collectivités territoriales. Paris, Décembre 2003. Myers, Nancy J. e Carolyn Raffensperger (eds.), - Precautionary tools for reshaping environmental policy, the MIT press, Cambridge, Massachusetts, 2006.

Nabais, Casalta - "Solidariedade Social, Cidadania e Direito Fiscal”, in: Estudos Jurídicos e Económicos em Homenagem ao Prof. Doutor António de Sousa Franco, vol II, Coimbra Editora, 2006, p. 642-645. O'Riordan, Timothy e James Cameron, - Interpreting the Precautionary Principle, Earthscan, 1994. Ost, François - “Ecología y Derechos del Hombre”, Humana lura, n.ำ, 1996, p.208.

Pearce, David - The Precautionary Principle and Economic Analysis", in: Timothy O’Riordan e James Cameron, (ed.) Interpreting the Precautionary Principle, Earthscan, 1994.

Pes, João Hélio Ferreira e Rafael Santos de Oliveira (coord.) - Direito Ambiental Contemporâneo, Prevenção e Precaução, Juruá Editora, Curitiba, 2009.

Ploeg, Frederick van der - "Prudent Budgetary Policy. Political Economy of precautionary taxation" CESifo - Münchener Gesellschaftzur Förderung der Wirtschaftswissenschaften - working paper, n. ${ }^{1973}$, de Abril de 2007. 
Pontier, Jean-Marie, - «Le droit de la prévention des risques, droit en devenir des sociétés développées, d'aujourd'hui et de demain», in: Les plans de prévention des risques, Université Paul CézanneAix Marseille III, 2007.

Prieur, Michel - «L'irreversibilité et la Gestion des Déchets Radioactifs dans la Loi du 30 Décembre 1991», in: L'irreversibilité, Revue Juridique de l'Environnement, no spécial, 1998, p. 125.

Rèmond-Gouilloud, Martine - «L'Irreversibilité: de l'Optimisme Dans l'Environnement», in: Révue Juridique de l'Environnement, numéro spécial, 1998, p. 17.

Renn, Ortwin - "Concepts of Risk: a Classification”, in: Social Theories of Risk, Sheldon Krimsky e Dominic Golding (Ed) Praeger, London, 1992.

Romi, Raphael, - «Risque et droit quelles problématiques?» in: La prévention des risques naturels, échec ou réussite des Plans d'exposition aux risques?, Université de Nice Sophie Antipolis, 1993.

Sadeleer, Nicolas de - "Les Avatars du Principe de Précaution en Droit Public. Effet de Mode au Révolution Silencieuse?» in: Revue Française de Droit Administratif, 2001, Mai-Juin, p. 559.

Sansseverino-Godfrin, Valérie - Le cadre juridique de la gestion des risques naturels, Editions Tec Doc, Paris, 2008.

Schomberg, René von - “The Precautionary Principle and its Normative Challenges, in: Implementing the Precautionary Principle. Perspectives and Prospects, Edward Elgar, Cheltenham, 2008.

Ségur, Philippe - «La catastrophe et le risque naturels : essai de définition juridique» in: Revue du Droit Public et de la Science Politique en France et a l'Étranger. - 0035-2578. - N. 6 (1997), p. 1699.

Sendim, Cunhal - Responsabilidade Civil por danos ecológicos. Da reparação do dano através de restauração natural, Coimbra Editora, 1998.

Silva, Vasco Pereira da - “"Mais vale prevenir do que remediar», prevenção e precaução no Direito do Ambiente", in: Direito Ambiental Contemporâneo, Prevenção e Precaução, Juruá Editora, Curitiba, 2009.

Sluijs, Joren van der e Wim Turkenburg - "Climate Change and the precautionary principle”, in: Implementing the Precautionary Principle. Perspectives and Prospects, Edward Elgar, Cheltenham, 2008.

Somers, Margatet R. - Genealogies of citizenship. Markets, statelessness and the right to have rights, Cambridge University Press, 2008.

Stirling, Andy, Ortwin Renn e Patrick van Zwanenberg, - "A Framework for the precautionary governance of food safety: integrating science and participation in the social appraisal of risk", in: Implementing the Precautionary Principle. Perspectives and Prospects, Edward Elgar, Cheltenham, 2008.

Sunstein, Cass - Laws of Fear - Beyond the Precautionary Principle. Cambridge University Press, Cambridge 2005 .

Sunstein, Cass - Risk and Reason. Safety, Law and the Environment, University of Chicago Law School, Cambridge University Press, 2002.

Sunstein, Cass - Worst Case Scenarios (Harvard University Press, Cambridge, 2007.

Thibierge, Catherine - «Avenir de la Responsabilité, Responsabilité de l'Avenir», Le Recueil Dalloz, 4 Mars 2004, n우, 7150, p. 582.

Thibierge, Catherine - «Le Droit Soupe. Réflexions sur les Textures du Droit», in: Révue Trimestrielle de Droit Civil, Octobre, Décembre 2003, p. 617.

Tickner, Joel e David Kriebel, - "The role of Science and Precaution in environmental and publick helath policy", in: Implementing the Precautionary Principle. Perspectives and Prospects, Edward Elgar, Cheltenham, 2008.

Trickett, Susan Bell e J. Gregory Trafton - “What if...”: The Use of Conceptual Simulations in Scientific Reasoning”, in: Cognitive Science Vol. 31, n. $\stackrel{0}{5}_{5}$, September-October 2007 , p. 843-875.

Warter, Frederick - “What if? Versus if it ain't broke, don’t fix it”, in: Timothy O’Riordan e James Cameron, (ed.) Interpreting the Precautionary Principle, Earthscan, 1994.

Whiteside, Kerry H. - Precaucionary Politics. Principle and Practice in Confronting Environmental Risk, Massachusetts Institute of Technology", 2006.

Zotouni, Françoise - «Les Personnes Publiques Iniciatrices d'Operations d'Aménagement et l'Obligation de Relogement des Occupants», in: Mélanges en l'Honneur d' Henri Jacquot, Presses Universitaires d'Orléans, 2006, p. 597-616. 